Kisspeptin modulates the activity of the stress system and associated behaviours, the body temperature and nociception

A dissertation submitted for the degree of Doctor of Philosophy by

Krisztina Anna Csabafi, M.D.

Department of Pathophysiology

Faculty of Medicine

University of Szeged 


\section{Contents}

List of Figures iv

$\begin{array}{lll}\text { Publications } & \text { v }\end{array}$

Abbreviations vii

$\begin{array}{lll}1 & \text { Introduction } & 1\end{array}$

1.1 Kisspeptins . . . . . . . . . . . . . . . . . . . . . . 1

1.1.1 The RF-Amide Family and the Discovery of Kisspeptin . . . . 1

1.1 .2 Structure of Kisspeptins and Their Receptor Targets . . . . . 2

1.1.3 Distribution of the Kisspeptin System in the Brain . . . . . . 3

1.1.4 The Physiological Role of Kisspeptin, and Its Pathophysiological Implications . . . . . . . . . . . . . . . . . . . 4

$1.2 \quad$ Stress, Behaviour, Temperature, and Pain . . . . . . . . . . . 5

1.2.1 The Hypothalamic-Pituitary-Adrenal Axis . . . . . . . . . . . 5

$1.2 .2 \quad$ Behavioural Adaptation to Stress . . . . . . . . . . . . 7

1.2.3 The Hypothalamic Control of the Body Temperature . . . . . 8

1.2 .4 Pain Modulation . . . . . . . . . . . . . . . . . 9 9

1.3 The Goal of Our Experiments . . . . . . . . . . . . . . . . . . . . . . 11

2 Kisspeptin Modulates HPA axis activity, behaviour and temperat$\begin{array}{lr}\text { ure of rats } & 12\end{array}$

$2.1 \quad$ Introduction . . . . . . . . . . . . . . . . . . . . . . . . . . . . . . . . 12

2.2 Materials and Methods . . . . . . . . . . . . . . . . . . . . . 12

2.2 .1 Animals . . . . . . . . . . . . . . . . . . . . . . . . . . 12

2.2 .2 Surgery $\ldots \ldots \ldots \ldots \ldots$. . . . . . . . . . . . . . . . . . . 12

2.2 .3 Treatments . . . . . . . . . . . . . . . . . . . . . . . . 13

2.2 .4 Plasma Corticosterone Measurement . . . . . . . . . . . . . . 14

2.2 .5 Telemetry . . . . . . . . . . . . . . . . . . . . . . . . . 14

2.2 .6 Open Field Test . . . . . . . . . . . . . . . . . . . . . . . . . . 15

$2.2 .7 \quad$ Elevated Plus Maze Test . . . . . . . . . . . . . . . . . . . . 15

2.2 .8 Statistical Analysis . . . . . . . . . . . . . . . . . . . 15

2.3 Results . . . . . . . . . . . . . . . . . . . . . . . . . . . . . . . . . . . . . 16

2.3 .1 Effect of KP-13 on Corticosterone Secretion . . . . . . . . . . 16

2.3.2 Effect of KP-13 on Spontaneous Locomotion and Core Tem-

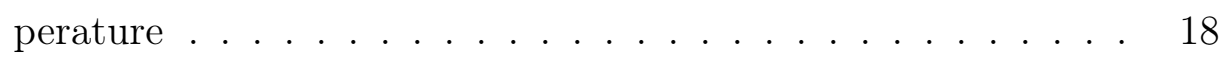

$2.3 .3 \quad$ Effect of KP-13 on Open Field Behaviour. . . . . . . . . . . . 19

2.3 .4 Effect of KP-13 on Elevated Plus Maze Behaviour . . . . . . . 19 
2.4 Discussion . . . . . . . . . . . . . . . . . . . . . . . . . . . . . . . 21

3 Kisspeptin Inhibits Depressive Behaviour in Mice 24

3.1 Introduction . . . . . . . . . . . . . . . . . . . . . . . . 24

3.2 Materials and Methods . . . . . . . . . . . . . . . . . . . . . . . 24

3.2 .1 Animals . . . . . . . . . . . . . . . . . . . . 24

3.2 .2 Surgery $\ldots \ldots \ldots \ldots \ldots$

3.2 .3 Treatments . . . . . . . . . . . . . . . . . . . 24

3.2 .4 Forced swimming test . . . . . . . . . . . . . . . . . 25

3.2 .5 Statistical analysis $\ldots \ldots \ldots . \ldots . \ldots . \ldots 25$

3.3 Results . . . . . . . . . . . . . . . . . . . . . . . . . . . . . . 25

3.3 .1 Effect of KP-13 on forced swimming test . . . . . . . . . . . . 25

3.3 .2 Effect of Antagonist Treatments on the KP-13-Induced Anti depressive Behaviour . . . . . . . . . . . . . . . . 26

3.4 Discussion . . . . . . . . . . . . . . . . . . . . . . . . . . . . . . . . . . . . 29

4 Kisspeptin Modulates Pain Sensation in Mice 32

4.1 Introduction . . . . . . . . . . . . . . . . . . . . . . . . . . . . 32

4.2 Materials and methods . . . . . . . . . . . . . . . . . . . . 32

4.2 .1 Animals . . . . . . . . . . . . . . . . . . . . . . . . . 32

4.2 .2 Surgery . . . . . . . . . . . . . . . . . . . . . . . . . . 32

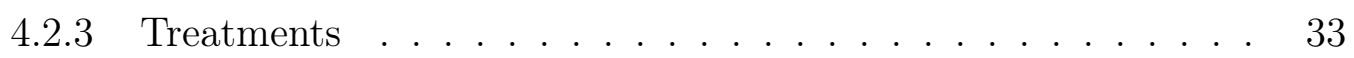

4.2 .4 Tail-Flick test . . . . . . . . . . . . . . . . . . . . . 33

4.2 .5 Statistical Analysis . . . . . . . . . . . . . . . . . . . 34

4.3 Results . . . . . . . . . . . . . . . . . . . . . . . . . . . . . 34

4.3 .1 Effect of KP-13 on Tail-Flick Latency . . . . . . . . . . . . . . 34

4.3 .2 Effect of KP-13 on Challenge Dose of Morphine . . . . . . . . 35

4.3 .3 Effect of KP-13 on Acute Morphine Tolerance . . . . . . . . . 36

4.3.4 Effect of KP-13 on Naloxone-Precipitated Acute Morphine Withdrawal . . . . . . . . . . . . . . . . . 36

4.4 Discussion . . . . . . . . . . . . . . . . . . . . . . . . . . . . . . . . . 38

5 Conclusion 42

$5.1 \quad$ Kisspeptin and the Stress Response . . . . . . . . . . . . . . . . . . . 42

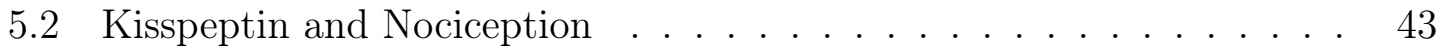

5.3 Kisspeptin and Circadian Rhythm . . . . . . . . . . . . . . . . . . . . 43

5.4 Limitations of the Study and Implications for the Future . . . . . . . 44

$\begin{array}{lll}6 & \text { Summary } & 45\end{array}$ 
\begin{tabular}{lll}
\hline 7 & Összefoglalás & 47
\end{tabular}

$\begin{array}{lll}8 & \text { Acknowledgments } & 50\end{array}$

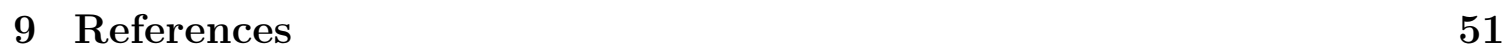




\section{List of Figures}

$1 \quad$ The RF-amide family and their respective receptors [82] $\ldots \ldots$. . . . 2

$2 \quad$ Kisspeptins [171] . . . . . . . . . . . . . . . . . . . 2

$3 \quad$ Distribution of kisspeptin and its receptor in the rat brain [217] . . . 4

4 Regulation of HPG axis by kisspeptin [157]. . . . . . . . . . . . . . . 4

5 The effect of KP-13 on the hypothalamus-pituitary-adrenal system. . 16

6 The effect of aCRF on KP-13-evoked activation of the hypothalamuspituitary-adrenal system . . . . . . . . . . . . . . 17

7 The effect of AVP ANT on the KP-13-induced activation of the hypothalamuspituitary-adrenal system . . . . . . . . . . . . . . 17

$8 \quad$ The effect of KP-13 on the spontaneous motor activity . . . . . . . . 18

$9 \quad$ The effect of KP-13 on the core temperature . . . . . . . . . . . . . . 18

10 The effect of KP-13 on exploratory locomotor activity . . . . . . . . . 19

11 The effect of KP-13 on elevated plus maze behaviour . . . . . . . . . 20

12 The effect of the AVP1R antagonist (AVP ANT) on KP-13-induced

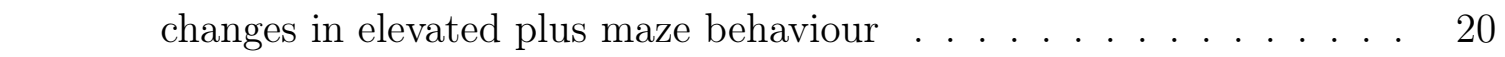

13 The effect of kisspeptin-234 on KP-13-induced changes in elevated plus maze behaviour . . . . . . . . . . . . . . . . . . . 21

14 The effect of KP-13 on depressive behaviour in the modified mouse forced swim test (FST) . . . . . . . . . . . . . . . . . 26

15 The effect of a nonselective $\alpha$-adrenergic receptor antagonist, phenoxybenzamine (POB) on KP-13-induced antidepressant-like action in modified mouse forced swim test (FST) . . . . . . . . . . . . . . 27

16 The effect of a nonselective $\alpha$-adrenergic receptor antagonist, yohim\begin{tabular}{|c|}
\hline bine (YOH) on KP-13-induced antidepressant-like action in modified \\
\hline
\end{tabular}

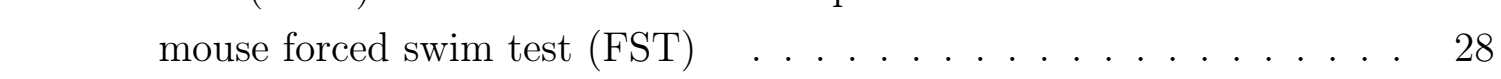

17 The effect of a nonselective $5-H_{2}$ serotonergic receptor antagonist, \begin{tabular}{|c|}
\hline cyproheptadine $(\mathrm{CPH})$ on KP-13-induced antidepressant-like action in \\
\hline
\end{tabular} modified mouse forced swim test (FST) . . . . . . . . . . . . . 28

18 The effect of KP-13 on pain sensitivity in the tail-flick test . . . . . . 35

19 The effect of KP-13 on morphine-induced analgesia in the tail-flick test 35

20 The effect of KP-13 on acute morphine tolerance in the tail-flick test 36

21 The effect of KP-13 on jumping behaviour in naloxone-precipitated morphine withdrawal . . . . . . . . . . . . . 37

22 The effect of KP-13 on the hypothermia induced by naloxone-precipitated morphine withdrawal . . . . . . . . . . . . . . 38 


\section{Publications}

\section{Original publications the presented work is based on:}

I Csabafi K, Jászberényi M, Bagosi Z, Lipták N, Telegdy G. Effects of kisspeptin13 on the hypothalamic-pituitary-adrenal axis, thermoregulation, anxiety and locomotor activity in rats. Behav Brain Res 2012;241C:56-61. IF:3.391

II Tanaka M, Csabafi K, Telegdy G. Neurotransmissions of antidepressant-like effects of kisspeptin-13. Regul Pept 2013;180:1-4. IF:2.014

III Csabafi K, Kincses B, Bagosi Z, Telegdy G. Kisspeptin alters the acute effects of morphine in mice In preparation, 2014

Cumulative impact factor: $\mathbf{5 . 4 0 5}$

\section{Other original papers published during the $\mathrm{PhD}$ fellowship:}

I Bagosi Z, Csabafi K, Palotai M, Jászberényi M, Földesi I, Gárdi J, Szabó G, Telegdy G. The effect of urocortin I on the hypothalamic ACTH secretagogues and its impact on the hypothalamic-pituitary-adrenal axis. Neuropeptides 2014;48 (1): 15-20. IF:2.546

II Jászberényi M, Bagosi Z, Csabafi K, Palotai M, Telegdy G. The actions of neuropeptide SF on the hypothalamic-pituitary-adrenal axis and behavior in rats. Regul Pept 2014;188 46-51. IF:2.014

III Bagosi Z, Csabafi K, Palotai M, Jászberényi M, Földesi I, Gárdi J, Szabó G, Telegdy G. The interaction of Urocortin II and Urocortin III with amygdalar and hypothalamic cotricotropin-releasing factor (CRF) - Reflections on the regulation of the hypothalamic-pituitary-adrenal (HPA) axis. Neuropeptides 2013;47 (5): 333-338. IF:2.546

IV Lipták N, Dochnal R, Csabafi K, Szakács J, Szabó G. Obestatin prevents analgesic tolerance to morphine and reverses the effects of mild morphine withdrawal in mice. Regul Pept 2013. IF:2.014

V Palotai M, Bagosi Z, Jászberényi M, Csabafi K, Dochnal R, Manczinger M, Telegdy G, Szabó G. Ghrelin and nicotine stimulate equally the dopamine release in the rat amygdala. Neurochem Res 2013;38 (10): 1989-1995. IF:2.551

VI Palotai M, Bagosi Z, Jászberényi M, Csabafi K, Dochnal R, Manczinger M, Telegdy G, Szabó G. Ghrelin amplifies the nicotine-induced dopamine release in the rat striatum. Neurochem Int 2013;63 (4): 239-243. IF:2.65 
VII Bagosi Z, Csabafi K, Jászberényi M, Telegdy G. The effects of corticotropinreleasing factor and the urocortins on hypothalamic gamma-amino butyric acid release-the impacts on the hypothalamic-pituitary-adrenal axis. Neurochem Int 2012;60 (4): 350-354. IF:2.659

VIII Lipták N, Dochnal R, Babits A, Csabafi K, Szakács J, Tóth G, Szabó G. The effect of pituitary adenylate cyclase-activating polypeptide on elevated plus maze behavior and hypothermia induced by morphine withdrawal. Neuropeptides 2012;46 (1): 11-17. IF:2.067

IX Csabafi K, Jászberényi M, Bagosi Z, Tóth G, Wollemann M, Telegdy G. The action of a synthetic derivative of Met5-enkephalin-Arg6-Pher on behavioral and endocrine responses. Peptides 2011;32 (8): 1656-1660. IF:2.434

Total impact factor: $\mathbf{2 6 . 8 8 6}$ 


\section{Abbreviations}

aCRF - $\alpha$-helical CRF (9-41)

ACTH - Adrenocorticotropin Hormone

Amy - Amygdala

ANOVA - Analysis of Variance

AR - Adrenerg Receptor

ARC - Arcuate Nucleus

AVP - Arginine Vasopressin

AVP ANT - Arginine Vasopressin receptor 1 antagonist

AVP1R - Arginine Vasopressin receptor 1

AVPV - Anteroventral Periventricular

Area

BNST - Bed Nucleus of Stria Terminals

CNS - Central Nervous System

CRH - Corticotropin-Releasing Hormone

EPM - Elevated Plus Maze

FKBP5 - FK506 binding protein 51 gene

FSH - Follicular Stimulating Hormone

FST - Forced Swimming Test

GC - Glucocorticoid

GnRH - Gonadotropin Releasing Hormone
GR - Glucocorticoid Receptor

HPA - Hypothalamic-Pituitary-Adrenal

HPG - Hypothalamic-Pituitary-Gonadal

icv. - intracerebroventricular

ip. - intraperitoneal

KISS1R - Kisspeptin Receptor 1

KP-10 - Kisspeptin-10

KP-13 - Kisspeptin-13

KP-54 - Kisspeptin-54

LH - Luteinizing Hormone

MOR - $\mu$ Opioid Receptor

NPAF - Neuropeptide AF

NPFF - Neuropeptide FF

NPFF1R - Neuropeptide FF Receptor 1

NPFF2R - Neuropeptide FF Receptor 2

OF - Open Field

PeN - Periventricular Nucleus

POA - Preoptic Area

PrRP - Prolactin Releasing Peptide

PVN - Paraventricular Nucleus

sc. - subcutan

SNP - Single Nucleotide Polymorphism 


\section{Introduction}

\section{$1.1 \quad$ Kisspeptins}

\subsubsection{The RF-Amide Family and the Discovery of Kisspeptin}

The tetrapeptide FMRFamide was isolated from the ganglia of the clam as a cardioexcitatory peptide approximately 30 years ago [174. Later on, it proved to be the first member of a family of peptides, whose members share an N-terminal sequence homology [226]. Since then, the Arg-Phe (RF)-amide motif was found throughout the animal kingdom and until now, a total of five RF-amide peptide genes have been discovered in mammals. This gave rise to neuropeptides, such as the AF and FF, prolactin releasing peptide (PrRP), RFamide-related peptides, kisspeptins and the most recently found pyroglutamylated RFamide peptide [56]. They are widely distributed in the central nervous system $(\mathrm{CNS})$, but they vary in their structure and receptor preference [56] binding to either one or several G-protein coupled receptors [16, 82] (Figure 1). The literature shows that the effects of RF-amide peptides partially overlap but in case of some physiological parameters they exert opposite actions. Several studies show, for example, that RF-amide peptides play a prominent role in nociception: intracerebroventricular (icv.) administration cause hyperalgesia and inhibition of morphine-induced analgesia, which effect is shared by all RF-amide peptides [102, 50]. Furthermore, PrRP activates the hypothalamic-pituitary-adrenal (HPA) axis [129] and increases stereotyped locomotion [105] and pressor response [76]. Neuropepide AF (NPAF), on the other hand, also induces the HPA axis and locomotor activity. It causes a decrease in the heart rate and core temperature [79]. These discrepancies between the biological actions of the individual peptides may be attributed to the difference in their receptor selectivity and/or place of release and action. Nonetheless, in light of the above-mentioned data, other members of the RF-amide family, more specifically the kisspeptin, might also have a wider range of functions then so far assumed.

The discovery of the kisspeptin system started with the identification of the gene KISS1 [107], named after its place of discovery: Hershey, Pennsylvania, home of the Hershey's Kisses sweets, in 1996. KISS1 over-expression was found in metastasis suppressed melanoma cells suggesting a role for this gene in tumour progression. In the following years the KISS1 gene's antimetastatic effect has been investigated in multiple tumours and the loss of function mutation of the gene associated with a bad prognosis.1 However, as of yet the most important physiologic function of the kisspeptin system was realised in 2003, when the inactivating mutations of the gene encoding the receptor for kisspeptins (KISS1R or GPR54) was identified to be the

\footnotetext{
${ }^{1}$ See review [217.
} 


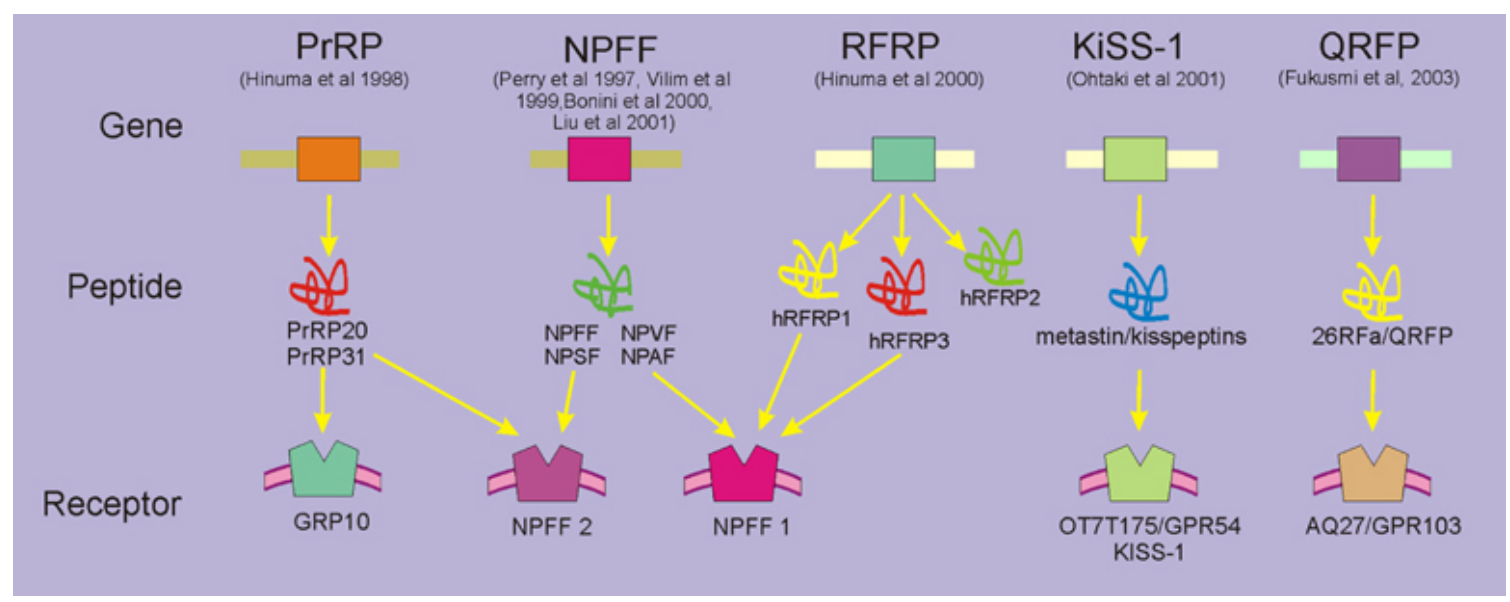

Figure 1: The RF-amide family and their respective receptors 82

cause of some forms of the isolated hypogonadotropic hypogonadisms [44, 194]. This observation led to an immense interest in the field to categorise the putative roles of the kisspeptin system in neuroendocrine control.

\subsubsection{Structure of Kisspeptins and Their Receptor Targets}

Kisspeptin, itself, was first isolated from the human placenta as the endogenous ligand of the orphan G-protein coupled receptor GPR54, later designated as KISS1R [158, 148, 98]. Kisspeptins are the product of the KISS1 gene and it must be noted that the comparison of the human, mouse and rat DNA sequences of this gene found them to be highly homologous [217]. In humans the KISS1 gene encodes a 145 amino acid long precursor peptide, which through multiple proteolytic steps will generate the major product consisting of 54 amino acids (KP-54), but its alternative cleavage can give rise to other biologically active derivatives containing 14, 13 or 10 amino acids, christened kisspeptin-14 (KP-14), kisspeptin-13 (KP-13) and kisspeptin-10 (KP-10), respectively [98, 94, 171] (Figure 2).

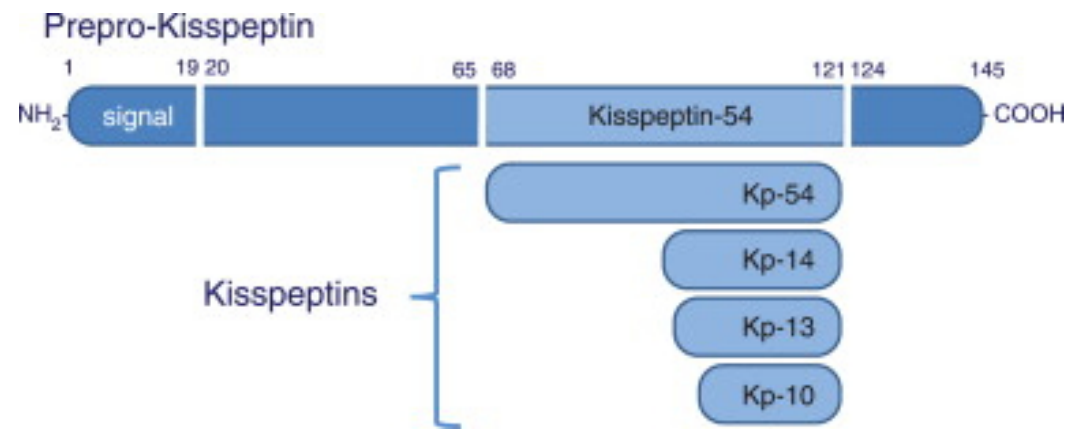

Figure 2: Kisspeptins [171]

Of note, there is some debate in the field concerning the possible endogenous role 
of the shorter products: mainly if they are generated through different proteolytic processes or rather they are a result of the degradation of the original KP-54 [217]. Nevertheless, the shorter derivatives maintain the same activity at the receptor level [183]. All fragments share the C-terminal part of the KP-54, and possess the ArgPhe $-\mathrm{NH}_{2}$ motif distinctive of the RF-amide family [56, 98, 157]. In rodent species, the structure of kisspeptins is very similar, however, there are slight differences: the major product contains 52 amino acids, and also the terminal Arg - Phe $-\mathrm{NH}_{2}$ sequence is substituted to $\mathrm{Arg}-\mathrm{Tyr}-\mathrm{NH}_{2}$ motif [217].

The KISS1R was originally cloned in 1999 from the rat brain and identified as a 396 amino acid polypeptide with seven transmembrane domains [106]. The receptor is coupled with Gaq signalling pathway, which through the activation of phospholipase C (PLC), causes a rise of inositol-(1,4,5)-triphosphate and diacyl-glycerol, ultimately leading to a biphasic intracellular $\mathrm{Ca}^{2+}$ mobilisation [157, 141]. However, cell type-dependently other signal transduction cascades might also mediate the effect of kisspeptins such as mitogen activated protein kinase (MAPK), calcineurin and $\mathrm{NF} \kappa \mathrm{B}[25]$. It must also be mentioned that recent evidence suggests that kisspeptin, beside the KISS1R, also activates the neuropeptide FF2 receptor (NPFF2R) [26], which have been implicated on autonomic, endocrine, behavioural and nociceptive processes [79, 165].

\subsubsection{Distribution of the Kisspeptin System in the Brain}

Both kisspeptin mRNA and protein were detected in peripheral tissues and CNS [107, 158, 148]. In the mouse and rat brain, Kiss1 mRNA expression is most prominent in the hypothalamus: Arcuate nucleus (ARC) as well as in the anteroventral periventricular area (AVPV) and the adjacent periventricular nucleus (PeN) [31, 20]. In addition, Kiss1 expression has also been found in the pre-optic area (POA), medial amygdala (Amy) and the bed nucleus of stria terminalis (BNST) [31]. Furthermore, reverse transcriptase polymerase chain reaction revealed expression of the KISS1 gene in the basal ganglia of humans as well [148].

The KISS1R mRNA in rat has been found in different forebrain regions including diagonal band of Broca (DBB), septum, POA, anterior and lateral hypothalamus, dorsomedial hypothalamic nucleus [78]. Similarly, abundant expression was shown in the hippocampus (Hpt), locus coeruleus (LC), Amy and the periaqueductal gray (PAG). In humans expression of the receptor mRNA was detected in the basal ganglia (CPut), Hpt, substantia nigra (SN), and, at low levels, thalamus (Th), cerebellum (C), and corpus callosum [148, 106, 57, 72] $:^{2}$

\footnotetext{
${ }^{2}$ See for more details $[94$.
} 


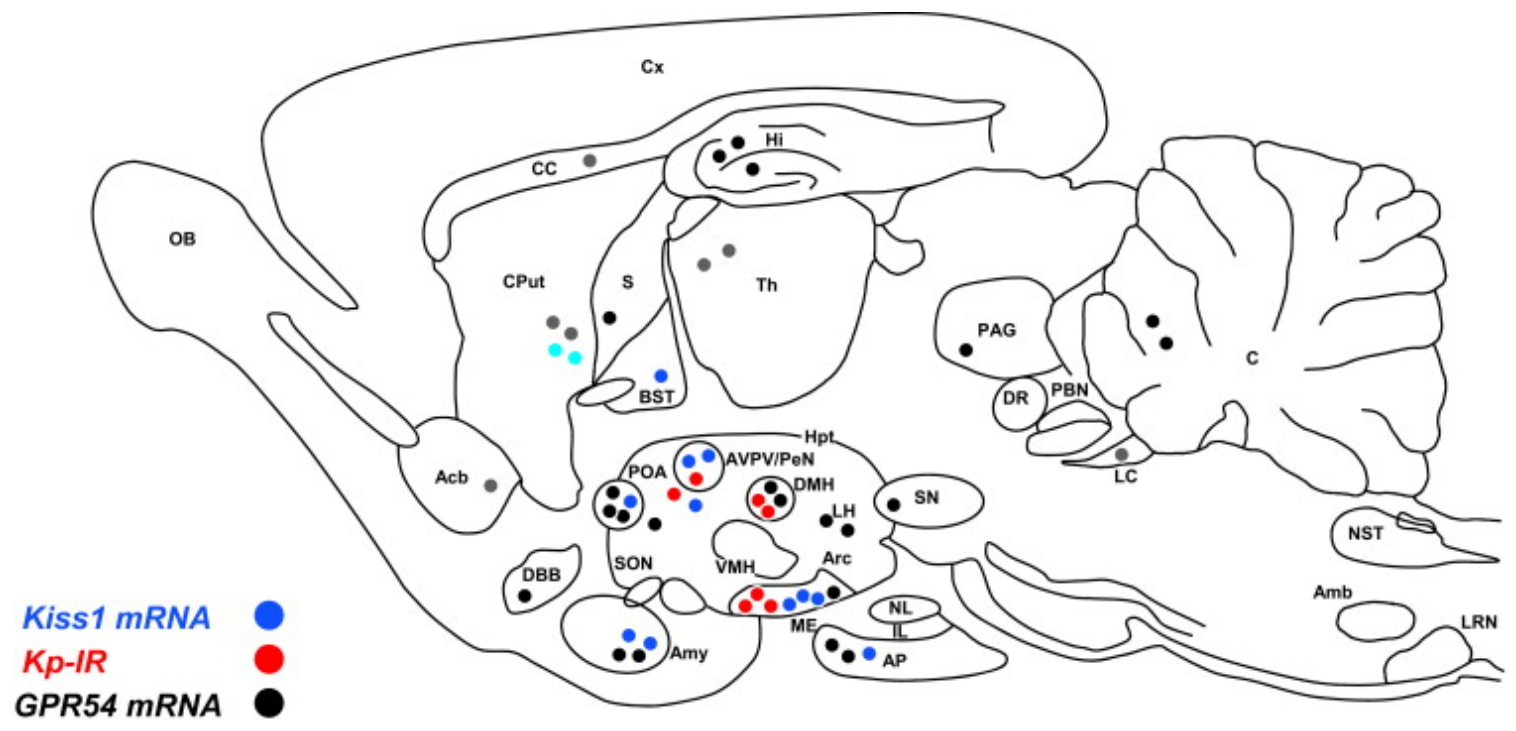

Figure 3: Distribution of kisspeptin and its receptor in the rat brain [217]

\subsubsection{The Physiological Role of Kisspeptin, and Its Pathophysiological Implications}

In 2003 it became evident that kisspeptin has an important role in reproductive biology. First of all, kisspeptin was found to stimulate gonadotropin releasing hormone $(\mathrm{GnRH})$ and ultimately luteinising hormone (LH) and follicular stimulating hormone (FSH) secretion [78, 138, 153, 62].

The majority of kisspeptin neurones are located in two distinct hypothalamic nuclei: AVPV/PeN and ARC [31]. These project to GnRH neurones, however, these kisspeptin neurones differ: they project to different parts of GnRH neurones [179, 37], they display different coexpression patterns [155] and sexual dimorphism [89]. This suggested a different role for them in the regulation of GnRH activity (Figure 4).

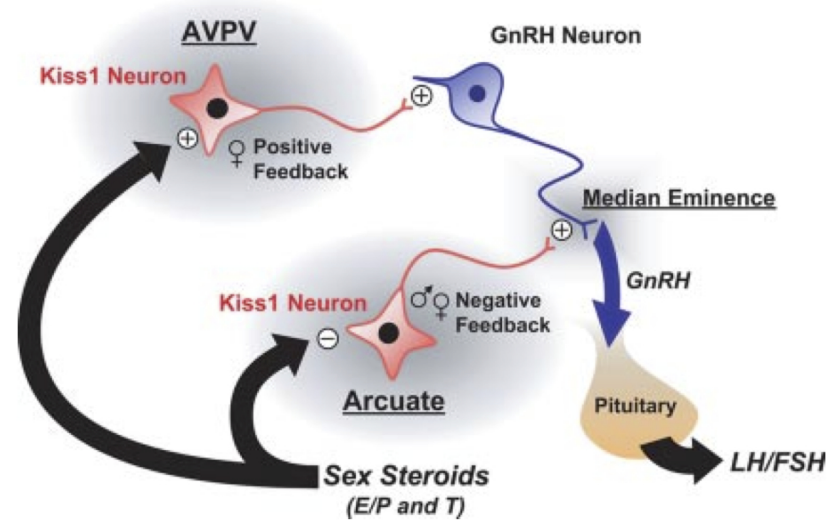

Figure 4: Regulation of HPG axis by kisspeptin [157] 
For a long time it was understood that gonadal steroids exert a negative feedback on reproductive axis, however, the exact site and mechanism was not known as GnRH neurones do not express the necessary receptors (androgen and $\alpha$-estrogen receptors (ER)), which suggested an upstream target for the negative feedback effect. Kisspeptin neurones in the AVPV/PeN and ARC are likely targets based on receptor expression profile, however, sex steroids have different actions on these two population of hypothalamic neurones. In the ARC Kiss1 gene expression significantly increased after gonadectomy in mice and returned to the previous level in case of testosterone and estradiol replacement [204, 203]. In contrast, expression of Kiss1 gene in the AVPV/PeN showed the opposite [204, 203]. These findings raised the idea that AVPV/PeN kisspeptin neurones might mediate the positive feedback effect of gonadal steroids, more specifically the pre-ovulatory LH surge that is only present in female mammals. This is supported by the fact that AVPV/PeN expresses ER $\alpha$ [203], it shows sexual dimorphism [88] and lesion of AVPV/PeN or kisspeptin antagonism results in blocked LH surge in female mice [92, 172]. Furthermore, a recent human study shows that kisspeptin administration resulted in early LH surge [81.

Kisspeptin has also been implicated in the development of puberty. This contention is not surprising considering that KISS1R defect results in primary hypogonadotropic hypogonadism [44, 194] and activating mutation of KISS1R leads to precocious puberty [216]. Puberty starts with the activation of the previously dormant GnRH neurones [66], the question, however, remains: what is the underlying mechanism and how is the optimal timing of puberty onset achieved. Recent evidence suggests a prominent role for kisspeptin neurones in this process based on expression and functional analysis, which include increased Kiss1 expression and kisspeptin secretion [152, 67, 196, 90, a rise in the number of Kiss1 neuronal fibres apposing on GnRH neurone [32], and finally increased expression of KISS1R on GnRH neurones at the time of puberty onset [152, 67, 196]. Furthermore, kisspeptin treatment was demonstrated to induce an early activation of the HPG (hypothalamic-pituitary-gonadal) axis [53], whereas antagonism of kisspeptin delays puberty onset in rodents [172]. All in all, these observations underline the prominent role of the kisspeptin system in the control of puberty. Do kisspeptin neurones play a central component of pubertal clock or a downstream effector is yet to be investigated.

\subsection{Stress, Behaviour, Temperature, and Pain}

\subsubsection{The Hypothalamic-Pituitary-Adrenal Axis}

Throughout life all organism are constantly challenged by actual or potential changes in the environment that are considered a threat to homeostasis; this is defined as stress. Adaptation to the perceived stressor requires a precisely controlled and co- 
ordinated activation of multiple systems: neuroendocrine, behavioural, immune and autonomic nervous systems [218]. The major endocrine response to stress is the activation of the HPA axis, which will result ultimately in the secretion of glucocorticoids (GCs), which act on multiple levels in the body to redirect energy resources [193, 135]. They are recognised by the glucocorticoid receptors (GRs) and their action is mediated by genomic mechanisms modifying the transcription of key regulatory proteins and by non-genomic mechanisms on cell signalling pathways providing a basis for rapid homeostatic regulation [21]. The end effects of GC action are widespread and mostly catabolic in nature, and thus if extended over time can take a powerful toll on the organism [221, 133, 134]. As a consequence, precise control of GCs is essential. The centre for the endocrine response to stress is a specific group of neurones found in the dorsomedial parvocellular subdivision of the paraventricular nucleus (PVN) of the hypothalamus [135, 211, 162]. These neurones produce corticotropin-releasing hormone $(\mathrm{CRH})$ that is needed for normal adrenocorticotropin hormone (ACTH) secretion under basal and stressed conditions and is the defining phenotypic feature of this cell type. Arginine vasopressin (AVP) is the other crucial co-expressed factor (among other peptides and neurotransmitters) that enhances the ACTH surge by potentiating the effect of $\mathrm{CRH}$ response [2].

Two distinct realms define HPA axis activity. Under unstressed conditions GC secretion undergoes a daily rhythm with peak concentration occurring at the beginning of the waking cycle in most vertebrates [111, 87]. During the waking phase a basal secretion of GCs is present leading to the partial occupation of GRs, which is critical for optimising the functional tone of numerous systems [76] in the body [159, 43]. Coordination of this rhythmic activity is achieved by inputs from the suprachiasmatic nucleus, the pacemaker of numerous bodily rhythms [65]. The second domain of HPA action is the control of corticosteroid secretion following acute and repeated stress [5, 7].

Different stressors trigger different responses. In point of fact, many factors influence the pattern and magnitude of the responses to stress such as duration (acute versus chronic), type (psychological or physical or both), stress context (the level of HPA axis activity at the time of stress), developmental stage, sex and genetic background of an organism [7, 51, 83]. Hence, it is hardly surprising that multiple distinct neuronal populations [74, 73] and multiple stress mediators act in concert to integrate these signals to generate an appropriate response. Various stress mediators have already been described, these include monoamine neurotransmitters (noradrenalin [145], dopamine [61], serotonin [142, 113]), neuropeptides (CRH family [149, 213] and AVP [156]) and steroid hormones [43, 118, 84] (cortisol in humans, corticosterone in rodents), all of which have their preferred activity in time and space. The classic stress-activated peptides are CRH and AVP, however several others have been 
implicated in mediating stress (orexin [207], ghrelin [80], opioids [46, 4] and RFamides) or counteracting the stress response under some conditions (oxytocin [156] and neuropeptide Y [195]) or may regulate stress-associated anxiety (for example, galanin [170] and substance P [69]).

\subsubsection{Behavioural Adaptation to Stress}

The integration of the stress response in the brain involves emotional and cognitive changes that will alter the behaviour of the animals to ensure their survival. A wealth of data in the literature demonstrate how stress mediators influence behaviour [10]. For example, CRH, the most prominent hypophyseotropic ACTH secretagogue, and its cognate receptors have a high expression in multiple brain regions, among them those that are relevant for emotional and cognitive functions (central and basolateral Amy, hippocampus, prefrontal cortex, locus coeruleus, BNST) [211, 220, 199]. Furthermore, central or site-specific administration of CRH results in well-defined behavioural effects [71, 117]. Icv. injection of CRH elicits increased anxiety-like behaviour and arousal [97, 96], decreased food intake [109], altered locomotor activity [210], decreased social interaction [48], reduced sexual behaviour [200] and sleep disturbances. Among these the first and best described was the increased arousal and context dependent changes in locomotor activity: in a non-stressed, familiar environment a dose-dependent rise, whereas in a novel, stressful environment a decrease of locomotion in the open/central areas of an arena, rearing and grooming behaviours were found [198, 85]. To elucidate the effect of stress mediators on behaviour, overexpression or knock-out transgenic mice models were developed, which overall supported the previously mentioned findings ${ }^{3}$.

Dysregulation of the HPA axis has been implicated in a number of stress related emotional diseases such as anxiety and depression. The current view on the pathogenesis of mental disorders is of a complex interaction between genetic and environmental factors. Ongoing research indicate that a genetic predisposition may be shared among mood and anxiety disorders and the clinical manifestation depends on the interaction between these and additional environmental factors [127]. The most important environmental factor is stress. Till now, a number of genetic variants have been identified that pose an environmentally sensitive genotype [19, 30]. For example, a single nucleotide polymorphism (SNP) in the gene for FK506 binding protein 51 (FKBP5), a GR regulator (co-chaperone), results in GR resistance that may alter HPA axis sensitivity [190]. Could FKBP5 SNPs moderate the effects of environmental trauma on the development of psychiatric disorders? Evidence so far suggest that the FKBP5 risk allele interacts with childhood trauma in humans as early trauma

\footnotetext{
${ }^{3}$ see review for further details [213]
} 
and consequent activation of GRs results in long-term demethylation of FKBP5 [95] providing an outlet for the development of an altered stress response and increased risk for stress-related disorders [14, 13, 12, 137]. Indeed, future investigations must focus on identifying the genetic background of these psychiatric diseases and linking them to environmental factors and the consequent neuroendocrine, neurotransmitter and neuroanatomical disruptions.

The known actions of the anxiolytic and antidepressant drugs and genetic studies aiming to identify predisposing gene polymorphisms implicate several monoaminergic systems in the pathogenesis of mood and anxiety disorders [168]: serotonin, norepinephrine and dopamine, however, in the CNS classic neurotransmitters are often wrapped and released together with neuropeptides [53], many of which are expressed in the limbic system suggesting a possible role in stress and emotionality. Several neuropeptides have been studied and implicated, the most relevant of them may be CRH, AVP, oxytocin, cholecystokinin, galanin, neuropeptide $\mathrm{Y}$ and opioids [65, 64, 120]. Galanin, for example, is colocalised in brainstem nuclei with monoamine and influences pain processing, feeding behaviour, other neuroendocrine and cardiovascular functions. Oxytocin and vasopressin are released from hypothalamic and limbic regions and they regulate anxiety, stress-coping and sociality. Central oxytocin exerts anxiolytic and anti-depressive effects, vasopressin the opposite [156]. Cholecystokinin was originally found in the gastrointestinal system, however, it is also widely expressed in the CNS, particularly in limbic regions and has been implicated in panic disorder [18].

The recent halt of psychiatric drug research by pharmaceutical companies revealing the failure in finding new avenues in treatment of psychiatric disorders calls for a new approach [55. Clearly, a better understanding of the pathomechanism of these diseases is crucial and much more effort is needed in identifying and investigating all factors that might influence stress-related behaviours.

\subsubsection{The Hypothalamic Control of the Body Temperature}

Body temperature of homeothermic animals is strictly regulated through a variety of involuntary thermoregulatory responses, such as shivering and brown adipose tissue thermogenesis, cutaneous vasomotion, sweating, panting, and piloerection. All these physiological responses are controlled by brain mechanisms in an orchestrated manner to optimise the internal thermal environment for appropriate molecular activities and reactions by bioactive proteins. The thermoregulatory system, however, has multiple other functions in the body: host defence from invading pathogens resulting in fever [184, psychological stress-induced hyperthermia as part of the stress response [160] and finally the regulation of energy consumption [103]. 
The thermoregulatory system consists of three components: sensory afferent part, integration centre, and efferent part [150]. The information on peripheral and central temperatures, immune signals, and other homeostatic parameters (e.g., osmolarity in tissue fluid) is delivered to the thermoregulatory centre in the POA, which is located in the rostral pole of the hypothalamus. Central, visceral and peripheral thermoreceptors provide the feedforward signals through collateral fibres rising from the spinal and trigeminal dorsal horns running to the lateral parabrachial nucleus, which in turn innervates the median pre-optic nucleus (MnPOA) by glutamatergic neurones. The MnPOA, in turn, provides GABAergic and glutamatergic input to the medial pre-optic area (MPO). After integration, the centre provides command signals to peripheral effectors through efferent neural and neuroendocrine pathways. In case of infection, $P G E_{2}$ accumulation at the site of medial pre-optic area (MPO) neurones will induce thermogenesis and shivering [150].

A variety of neuropeptides have been implicated in thermoregulatory control, most of them seem to have a role in energy balance or stress as well and may be responsible for integration between these homeostatic functions. A drop in core temperature might be observed in case of central anabolic neuropeptides (neuropeptide $Y$, orexins, melanin concentrating hormone) that stimulate food intake, whereas central catabolic neuropeptides (melanocortins, corticotropin releasing factor, cocaineamphetamine regulated peptide) have the opposite action [212].

\subsubsection{Pain Modulation}

Pain has long been in the focus of scientific research as it is one of the key physiological functions that protects against tissue damage, however it can be the source and accompaniment of debilitating diseases. Charles Darwin defined pain as "homeostatic emotion" that is essential for the survival of the species [38]. The organisation of pain is a complex network that displays plasticity functionally and structurally at multiple levels: molecular, synaptic, cellular, network [100]. This provides the framework for the dynamic changes in the neural matrix of pain, which if disrupted can progress into characteristic pathologic states, for example hyperalgesia, paraesthesia, dysesthesias, tactile allodynia and continuous, ongoing pain. Functional plasticity on the molecular level might involve transcriptional and post-translational modifications, synaptic modifications might be caused by varying receptor densities. Plasticity on the level of neurones in nociceptive pathways might be seen as an increase in the magnitude of responses to a defined stimulus or firing after cessation of stimulus that ultimately results in central amplification of pain (central sensitisation). Additionally, peripheral receptive fields of neurones can expand leading to hyperalgesia in uninjured regions. There is a tremendous potential of plasticity at system-level processing. The output 
of the system to a given peripheral stimulus may vary depending on how its wired, processed, coordinated and finally integrated. For example, spinal dorsal horn net output is decided by the incoming excitatory processes and the inhibition by spinal interneurons. Structural changes in synaptic spines, axon number, astrocyte and microglia presence further adds to the complexity of the pain network [100].

Various molecules may regulate pain processing by activating cell surface receptors in different temporal and spatial patterns. Most important are ligand-gated ion channels such as NMDA and AMPA-type glutamate receptors and ATP-gated P2X3type ion channels in the spinal cord that regulate neuronal excitability at a scale of microseconds to seconds [230]. Second, G-protein coupled receptors (GPCRs) are activated by multiple neurotransmitters and neuromodulators such as glutamate, adenosine, ATP, cannabinoids, opioids, prostaglandins and RF-amide neuropeptides among others that modulate pain over seconds to minutes. At last, receptor tyrosine kinases (RTKs) stimulated by different growth factors can exert there effect in a scale of minutes to hours [169]. Furthermore, by activating signalling transducers all three types of receptors may influence gene transcription resulting in long term regulation (see review for more details [100]).

Accumulating evidence strongly suggest a role for the RF-amide family in nociceptive mechanism. NPFF and analogues were found to have analgesic, pronociceptive and morphine modulating activities [56]. Although initially described as a solely antiopioid system, evidence proved otherwise and now it is believed that the nature of the pharmacology depends on the subtype targeted, route of administration, and opioid activity [102]. In point of fact, icv. administration of NPFF induce hyperalgesia and/or inhibit opioid-induced analgesia [58, whereas intrathecal injection results in the opposite [165. Both in vitro and in vivo pharmacological data suggest that these effects are mediated by the activation of NPFF1R and NPFF2R receptors [102], respectively. Distribution data indicate that NPFF2R is found most abundantly in the spinal cord, whereas in the brain both receptors are highly expressed, especially NPFF1R [16, 114, 231. Recent evidence suggest that all endogenous RF-amide peptides target not only their cognate receptors, but the NPFF1R and NPFF2R receptors as well, which raise the idea that all may take a part in pain modulation [50]. It is proposed that the $\mathrm{Arg}-\mathrm{Phe}-\mathrm{NH}_{2}$ motif is sufficient for binding with high affinity to both NPFF receptors [50]. Although much evidence has accumulated in the past couple of years that ascribes a critical role for the NPFF1R and NPFF2R receptors for the pain-modulating effects of RF-amide peptides, however, recent distribution data draws attention to other receptors, such as KISS1R and GPR10, and their endogenous ligands that are expressed in several brain areas involved in the control of pain [104]. For instance, both KISS1R and kisspeptin mRNAs and proteins have been detected in the dorsal horn of the spinal cord and in the dorsal root 
ganglia in rats [47, 140].

\subsection{The Goal of Our Experiments}

Taking into account the distribution of the kisspeptin system in the CNS and the available literature on other RF-amide peptides we have hypothesised that kisspeptin has a wider range of function in the CNS then so far assumed. Therefore, we have investigated,

I if centrally administered KP-13 has any impact on the stress response and associated behaviours, general activity and thermoregulation (in Chapter 2):

- We measured corticosterone response indicative of the endocrine HPA axis activity. After establishing the overall effect, we set out to identify the possible mechanism of action by applying CRH and AVP antagonist pretreatments as they are the most prominent activators of the endocrine axis.

- To assess the effect of KP-13 on anxiety-related behaviour we registered the explorative locomotor activity of animals in a novel environment (open field (OF) test) and anxiety in the elevated plus maze (EPM) test. Again, after determining the overall effect of kisspeptin we continued experiments with combined treatments with antagonists (AVP receptor 1 (AVP1R) antagonist and KISS1R antagonist) to explore how kisspeptin exerts it's effects on these parameters.

- We also investigated the effect of KP-13 on thermoregulation and general activity by continuously monitoring core temperature and spontaneous locomotor activity, both of which via a telemetric system.

II if KP-13 influences depressive behaviour in mice (in Chapter 3):

- For this purpose we observed the swim stress-induced behavioural despair in the modified forced swimming test (FST) in mice. Furthermore, to investigate the neurotransmitters involved in mediating the effect of kisspeptin different antagonist pretreatments were preformed.

III if KP-13, as a member of the RF-amide family also might play a role in pain modulation (in Chapter 4):

- Thus, in the present experiments we have studied the effect of KP-13 on pain sensitivity in the tail-flick test and the interaction between kisspeptin and acute morphine actions. 


\section{Kisspeptin Modulates HPA axis activity, beha- viour and temperature of rats}

\subsection{Introduction}

Taking the special importance of kisspeptin in the regulation of the HPG axis into account, and the fact that recent data suggests kisspeptin neuronal projections to the PVN [31, 20], it seems plausible that kisspeptin may take part in the control of the HPA axis, the interaction between the two systems and may exert further integrative activities in autonomic and endocrine control.

Therefore, in the present study, we investigated the central action of KP-13 on the stress response, behaviour and thermoregulation, which processes are controlled by the hypothalamus and the limbic system, where kisspeptin and its receptors are found in abundance [20. As an index of the activation of the HPA system the corticosterone response was used. The spontaneous locomotion and core temperature were monitored continuously with a telemetric system, while the exploratory and anxiety-associated behaviour was observed in OF and EPM tests.

\section{$2.2 \quad$ Materials and Methods}

\subsubsection{Animals}

Adult male Sprague-Dawley rats (Domaszék, Hungary) weighing 150-250 g were used at the age of 8 weeks. They were housed under controlled conditions $(12 / 12-\mathrm{h}$ light/dark cycle, lights on from 6:00 a.m., at constant room temperature) and were allowed free access to commercial food and tap water. The animals were kept and handled during the experiments in accordance with the instructions of the University of Szeged Ethical Committee for the Protection of Animals in Research, which approved these experiments. Approximately 160 animals in total were used in our experiments. Every experiment was carried out separately; the same animal has never been used for different experimental procedure.

\subsubsection{Surgery}

The animals were allowed 1 week to acclimatise before surgery. Subsequently, they were implanted with a stainless steel Luer cannula (10 mm long) aimed at the right lateral cerebral ventricle under pentobarbital (35 mg/kg, intraperitoneally (ip.)) anaesthesia. The stereotaxic coordinates were $0.2 \mathrm{~mm}$ posterior and $1.7 \mathrm{~mm}$ lateral to the bregma, and $3.7 \mathrm{~mm}$ deep from the dural surface, according to the atlas of Pellegrino et al. [31]. The cannula was secured to the skull with dental cement and 
acrylate. The rats were used after a recovery period of 5 days. All experiments were carried out between 8:00 and 10:00 a.m.

For implantation of the telemetric radio transmitter (E-Mitter: a temperatureactivity transponder), the rats were anaesthetised with pentobarbital ( $35 \mathrm{mg} / \mathrm{kg}$, ip.). The abdomen was opened by making a 2-cm midline incision along the linea alba. The E-Mitter was placed in the abdominal cavity, along the sagittal plane, in front of the caudal arteries and veins, but dorsal to the digestive organs. The abdominal wound was then closed with absorbable suture material, while the skin was closed with stainless steel suture clips. After a recovery period of 5 days, the rats were implanted with the stainless steel Luer cannula for icv. administration.

At the end of the experiments, the correct position and the permeability of the cannula were checked. In the behavioural studies, each rat was sacrificed under pentobarbital anaesthesia, and in the endocrinological experiments the head was collected after decapitation. Methylene blue was injected via the implanted cannula and the brains were then dissected. Only data from animals exhibiting the diffusion of methylene blue in all the ventricles were included in the statistical evaluation.

\subsubsection{Treatments}

Administration of KP-13 (Protocol 1) Rats were injected with different doses of KP-13 (Bachem, Switzerland) icv. in a volume of $2 \mu$ l over $30 \mathrm{~s}$ with a Hamilton micro-syringe, immobilisation of the animals being avoided during handling. The doses applied were $0.5,1,2$ or $5 \mu \mathrm{g}$ dissolved in $0.9 \%$ saline. Control animals received saline alone. Thirty minutes after peptide administration, the rats were decapitated to obtain trunk blood for corticosterone measurement or were subjected to behavioural testing.

Combined treatment with antagonists and KP-13 (Protocol 2) For this experimental setting, animals were subjected to combined treatment with a receptor blocker and KP-13. The following receptor blockers were used: AVP1R antagonist (AVP ANT) (Bachem, Switzerland) and kisspeptin-234 (Sigma) in the EPM studies, whereas AVP1R antagonist (AVP ANT) (Bachem, Switzerland) and $\alpha$-helical CRF (9-41) (aCRF) (Bachem, Switzerland) in the corticosterone measurements. Each antagonist was applied icv. in a concentration which per se does not affect the endocrine and behavioural paradigms: AVP ANT in a dose of $0.1 \mu \mathrm{g}, \mathrm{aCRF}$ in $1 \mu \mathrm{g}$ and kisspeptin-234 in $2 \mu \mathrm{g}$ was applied. Thirty min after the antagonist pretreatment the animals were treated with the dose of KP-13 that had proved most effective in Protocol 1. Thirty min after peptide treatment, the rats were subjected to EPM test or were sacrificed to obtain blood samples for corticosterone assays. 


\subsubsection{Plasma Corticosterone Measurement}

In order to determine plasma corticosterone concentrations, trunk blood was collected in heparinised tubes. The plasma corticosterone concentration was measured by the fluorescence assay described by Zenker and Bernstein [232] as modified by Purves and Sirett [175].

Sample Collection During the in vivo experiments trunk blood was collected from the animals into heparinised tubes and centrifuged for 10 minutes at $3000 \mathrm{rpm} .200$ $\mu \mathrm{l}$ of plasma were transferred to centrifuge tubes. In the case of the perfusion system 200 hundreds $\mu \mathrm{l}$ aliquots of the medium were transferred to centrifuge tubes.

Extraction A reagent blank of $200 \mu \mathrm{l}$ of distilled water and 2 corticosterone standards of the same volume containing $25 \mu \mathrm{g}$ or $50 \mu \mathrm{g}$, respectively were prepared. 5 $\mathrm{ml}$ of methylene chloride was delivered with an automatic pipette to each tubes and rocked for 30 minutes to allow for complete extraction of corticosterone by the solvent. The extract is centrifuged for $10 \mathrm{~min}$ at $3000 \mathrm{rpm}$. to eliminate any aqueous phase. Approximately $3.2 \mathrm{ml}$ of the lower hydrophobic phase was aspired with a glass syringe then transferred into another centrifuge tube.

Fluorescent Reaction $4 \mathrm{ml}$ fluorescent reagent [stable mixture of 2.4 volumes of sulphuric acid and 1.0 volume of $50 \%(\mathrm{v} / \mathrm{v})$ aqueous ethyl-alcohol] was added to the extract. The tubes were shaken vigorously for $15 \mathrm{~min}$, centrifuged at $3000 \mathrm{rpm}$. for 10 minutes and was allowed to stand at room temperature for 2 hours, which permitted the maximum development of fluorescence from corticosterone.

Measurement Emission intensity was measured from the lower sulphuric acid layer with Hitachi 204-A fluorescent spectrophotometer at $456 \mathrm{~nm}$ extinction and 515 emission wavelength. The concentration of corticosterone of the samples was calculated from the values of the standards, and in the in vivo experiments was expressed as $\mu \mathrm{g} / 100 \mathrm{ml}$.

\subsubsection{Telemetry}

Different doses of KP-13 $(1,2 \mu \mathrm{g})$ or saline alone were injected icv. into conscious rats, between 8:20 and 8:35 a.m. The animals had previously been implanted with an E-mitter (Mini Mitter, USA), which receives power from the radio frequency field generated by an energiser-reciever placed below the home cage. The system recorded the motor activity and core temperature every 10 minutes, the output of which then was processed by the VitalView program provided by the manufacturer. 


\subsubsection{Open Field Test}

In the OF test novelty-induced locomotor activity was assessed. The rats were removed from their home cages and placed at the centre of a white wooden open field box, the floor area of which measured $60 \times 60 \mathrm{~cm}$, marked into $3610 \times 10 \mathrm{~cm}$ squares. The standard source of illumination was a $60 \mathrm{~W}$ bulb at a height of $80 \mathrm{~cm}$. The observed parameters were horizontal locomotion, vertical locomotion, grooming and the number of defecations. The horizontal locomotor activity was characterised by the total number of squares crossed during a 5-min test session (square crossing), the vertical locomotion was determined by the number of rearings (standing on the hind legs), and the grooming activity was established by observing face washing, forepaw licking and head stroking. Every episode of face washing, forepaw licking and head stroking was counted as a separate grooming session, independently of how long it actually lasted.

\subsubsection{Elevated Plus Maze Test}

The EPM apparatus is a plus-shaped platform elevated $50 \mathrm{~cm}$ above the floor. It consists of two opposing arms (50 cm x $10 \mathrm{~cm}$ each) with $10 \mathrm{~cm}$ high enclosing walls (closed arms) and two arms with no walls (open arms). A $60 \mathrm{~W}$ light bulb at a height of $80 \mathrm{~cm}$ provided the illumination. The maze was cleaned between each session with 96\% ethyl-alcohol and all experiments were conducted between 8:00 a.m. and 10 a.m.

Naive rats were placed in the centre of the maze facing toward an open arm, and the number of entries per arm and the times spent in the various arms were recorded for a 5-min period by an observer who was blind to the experimental groups, sitting approximately $1.5 \mathrm{~m}$ away from the apparatus. The test is designed to assess anxiety based on the concept that the open arms are more aversive, and anxious rats therefore spend less time in them [225]. In the figures the ratio of time spent in open arms to total time spent in all arms, the ratio of entries to open arms to total number of entries and the total number of entries into all arms are presented.

\subsubsection{Statistical Analysis}

Data are presented as means \pm SEM. Statistical analysis of the results was performed by analysis of variance (ANOVA). For the corticosterone measurements, open field and elevated plus maze tests, one-way ANOVA was employed, followed by the HolmSidak post hoc test for multiple comparisons when the test prerequisites were fulfilled. When the test of the homogeneity of variances was not satisfied, nonparametric ANOVA on ranks (Kruskal-Wallis) was performed, followed by Dunn's test for multiple comparisons. For the evaluation of the telemetric recordings, repeated measure ANOVA was performed; only the means were plotted and the pooled standard deviation 
(PSD) is provided in the Figure captions. For the assessment of the experiments with combined treatments two-way ANOVA was used followed by the Holm-Sidak post hoc test. A probability level of less then 0.05 was accepted as indicating a statistically significant difference.

\subsection{Results}

\subsubsection{Effect of KP-13 on Corticosterone Secretion}

The icv. injection of KP-13 induced a dose-dependent elevation in basal plasma corticosterone level. The corticosterone level following the $2 \mu \mathrm{g}$ dose proved to be statistically different from the control $[\mathrm{F}(3,31)=3.955, \mathrm{p}<0.02 ;$ Figure 5]. aCRF per se $(1 \mu \mathrm{g} / 2 \mu \mathrm{l}$, icv.) did not affect the corticosterone secretion. In KP-13-treated rats, pretreatment with the aCRF did not reverse the KP-13-induced elevation of corticosterone $[\mathrm{F}(3,55)=4.783, \mathrm{p}<0.05$; Figure 6]. AVP ANT per se $(0.1 \mu \mathrm{g} / 2 \mu \mathrm{l}$, icv.) did not affect the hormone release. In the KP-13-treated rats, pretreatment with AVP ANT resulted in a marked decrease of KP-13 evoked corticosterone elevation $[\mathrm{F}(3,42)=16.623, \mathrm{p}<0.001 ;$ Figure 7$]$.

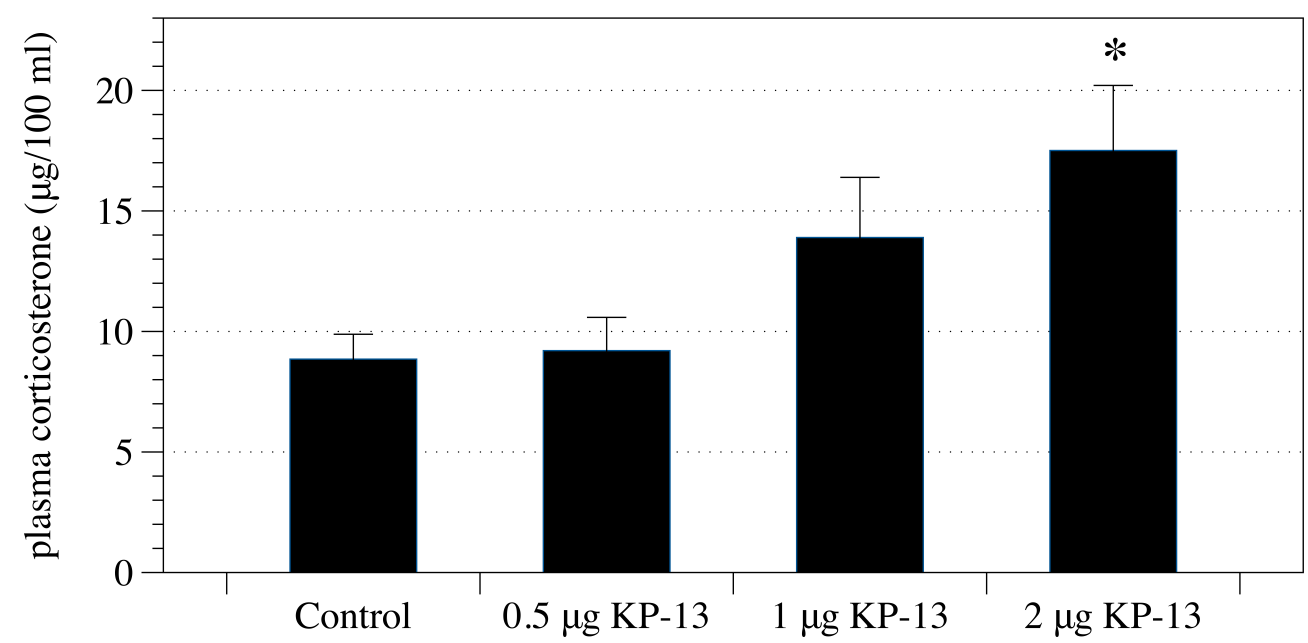

(8)

(9)

(9)

(9)

Figure 5: The effect of KP-13 on the hypothalamus-pituitary-adrenal system. ${ }^{5}$

\footnotetext{
${ }^{5}$ Mean and SEM are expressed. Numbers in parenthesis denote the number of animals used. * $\mathrm{p}<0.05$ vs. control.
} 


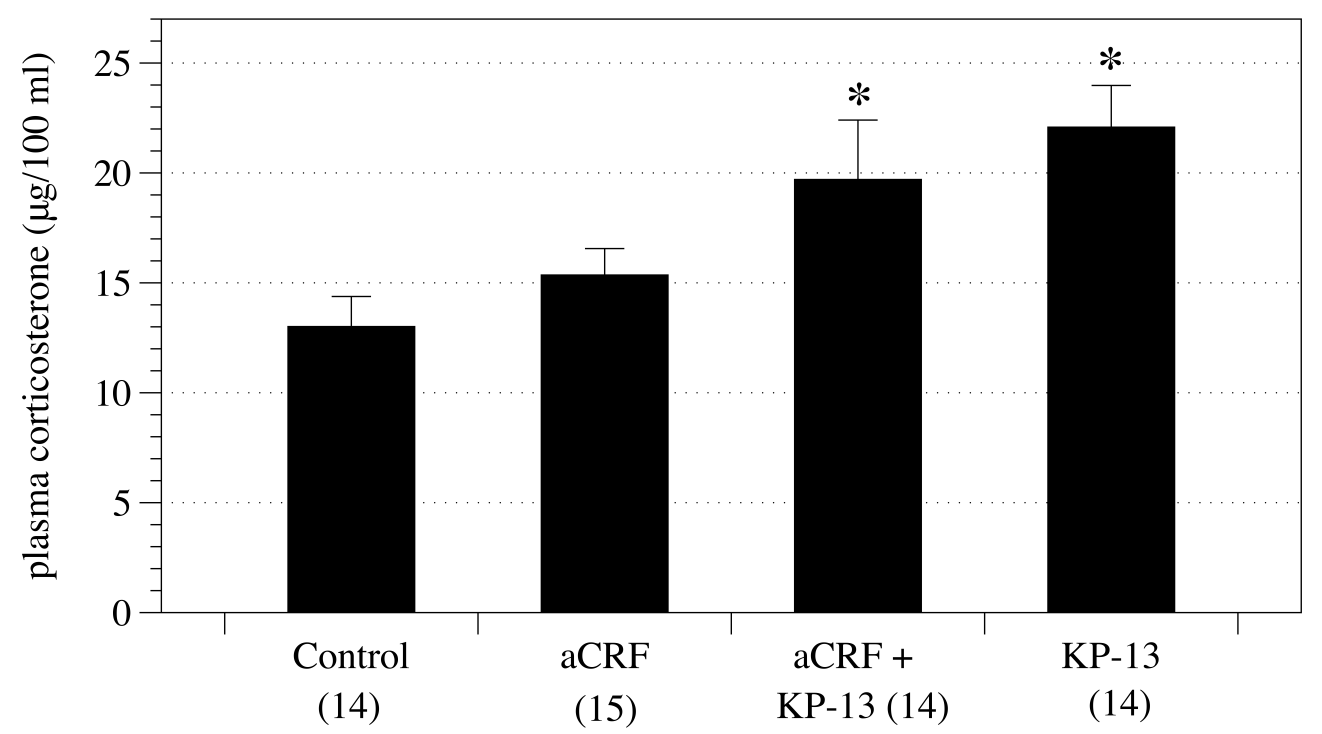

Figure 6: The effect of aCRF on KP-13-evoked activation of the hypothalamuspituitary-adrenal system ${ }^{6}$

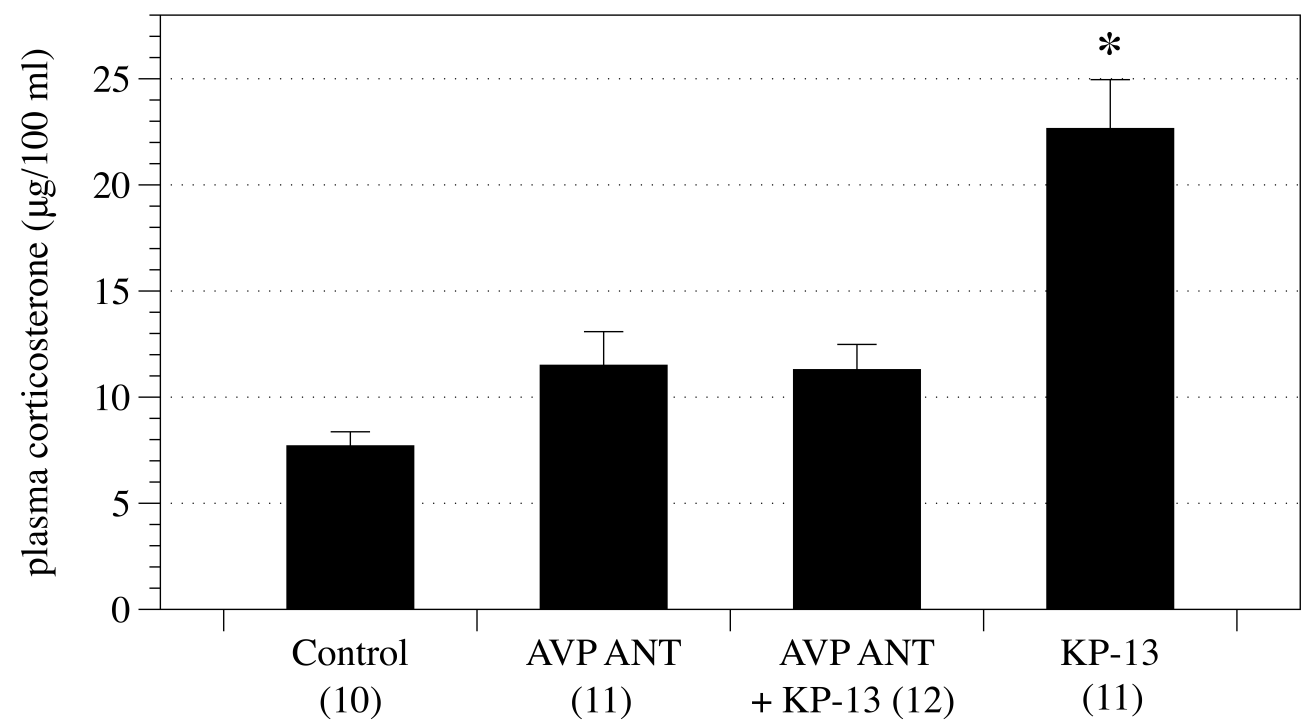

Figure 7: The effect of AVP ANT on the KP-13-induced activation of the hypothalamus-pituitary-adrenal system ${ }^{7}$

\footnotetext{
${ }^{6}$ Mean and SEM are expressed. Numbers in parenthesis denote the number of animals used. * $\mathrm{p}<0.05$ vs. control, $1 \mu \mathrm{g}$ aCRF.

${ }^{7}$ Mean and SEM are expressed. Numbers in parenthesis denote the number of animals used. * $\mathrm{p}<0.05$ vs. control, $0.1 \mu \mathrm{g}$ AVP ANT, $0.1 \mu \mathrm{g}$ AVP ANT $+2 \mu \mathrm{g} \mathrm{KP}-13$.
} 


\subsubsection{Effect of KP-13 on Spontaneous Locomotion and Core Temperat- ure}

After the KP-13 treatments between 8:20 and 8:35 a.m., increases in both locomotor activity $[\mathrm{F}(2,30)=5.842, \mathrm{p}<0.01 ;$ Figure 8$]$ and core temperature $[\mathrm{F}(2,30)=4.988$, $\mathrm{p}<0.02$; Figure 9] were observed in the home cages of the animals. In the case of locomotion, this effect was present only for approximately the next hour and the activity of the rats then returned to the level of the control animals, whereas in the case of the core temperature the hyperthermic action of KP-13 persisted for several hours after peptide administration.

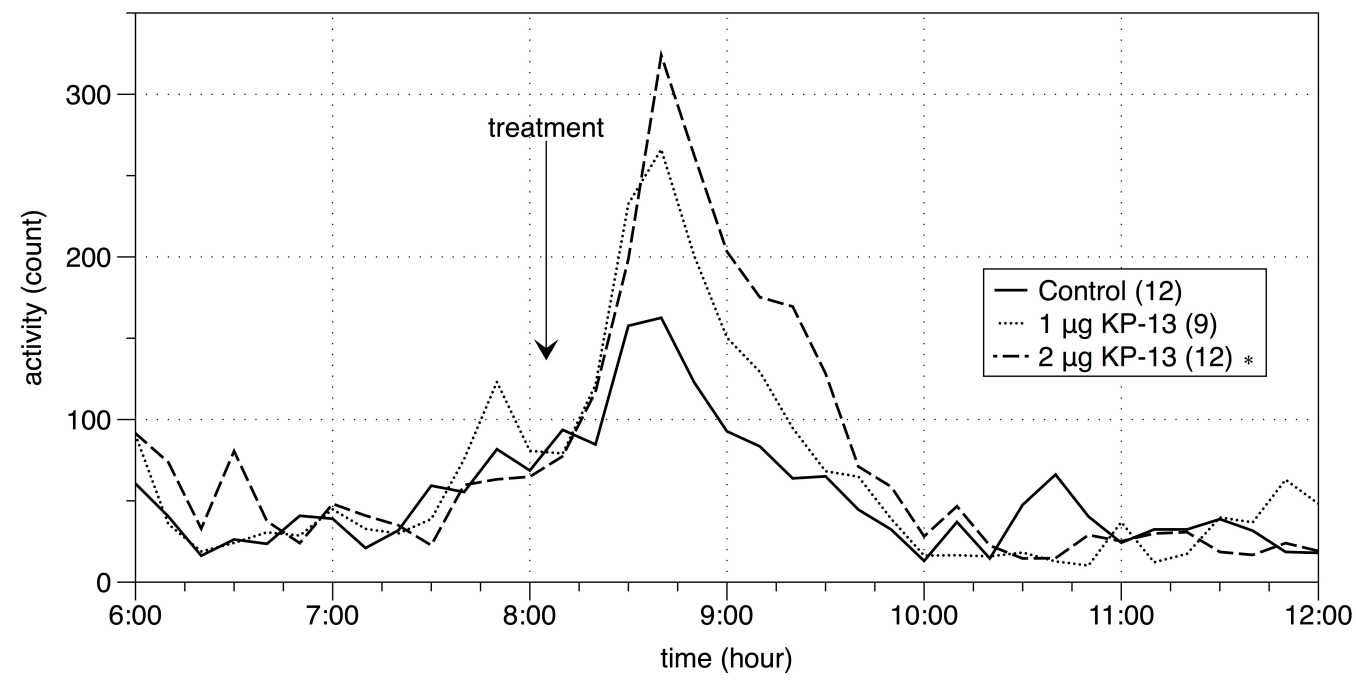

Figure 8: The effect of KP-13 on the spontaneous motor activity ${ }^{8}$

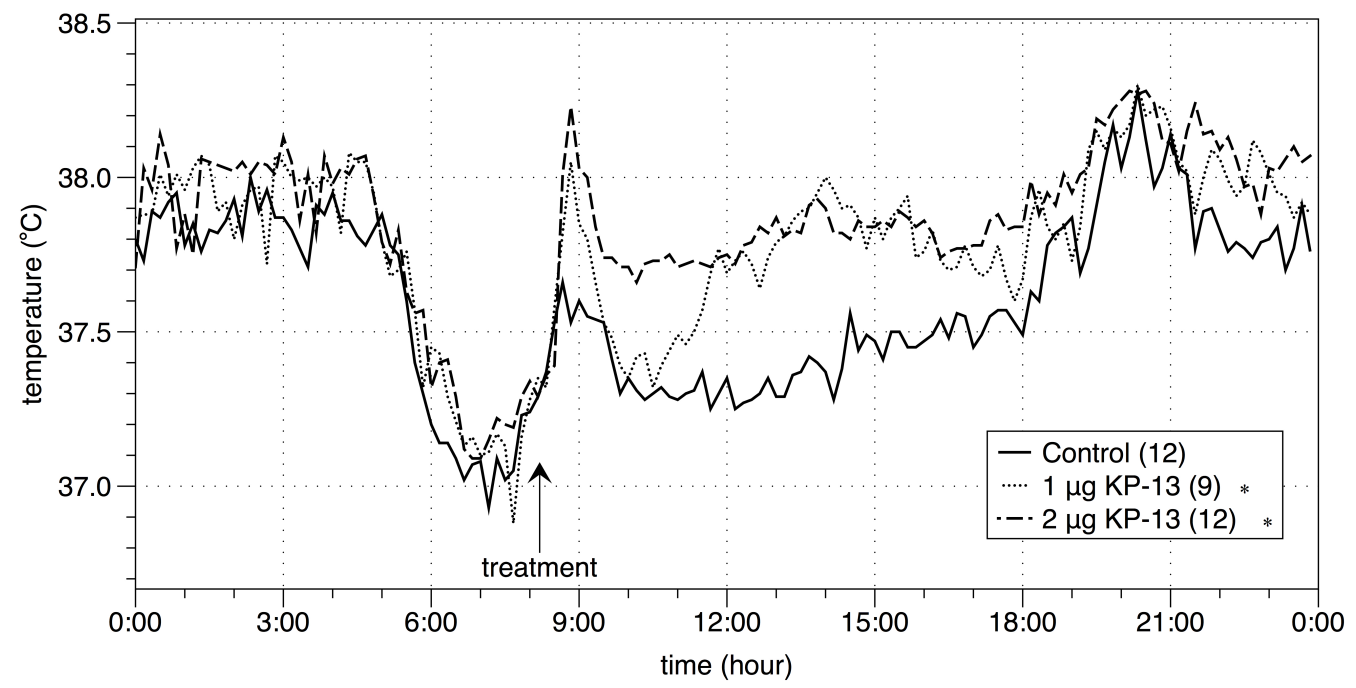

Figure 9: The effect of KP-13 on the core temperature ${ }^{9}$

\footnotetext{
${ }^{8}$ Data are expressed as means. The pooled standard deviations (PSDs): 62.34 for the control, 69.34 for the $1 \mu \mathrm{g} \mathrm{KP}-13$ treated group, 72.81 for the $2 \mu \mathrm{g} \mathrm{KP}-13$ treated group. Numbers in parenthesis denote the number of animals used. $* \mathrm{p}<0.05$ vs. control.
} 


\subsubsection{Effect of KP-13 on Open Field Behaviour}

KP-13 evoked a marked increase in the number of square crossings in the open field test $[\mathrm{F}(4,41)=3.001, \mathrm{p}<0.05$; Holm-Sidak post hoc test: $\mathrm{p}<0.01$ vs control; Figure $10]$, but did not affect the other recorded parameters: rearing activity $[\mathrm{F}(4,41)=$ 0.518, $\mathrm{p}=0.723]$, grooming $[\mathrm{H}=6.079, \mathrm{p}=0.193]$ or defecation $[\mathrm{F}(4,41)=1.225$, $\mathrm{p}=0.315]$ (not shown in Figures). The effect of KP-13 administered in a $1 \mu \mathrm{g}$ dose on the number of square crossings proved to be statistically significant.

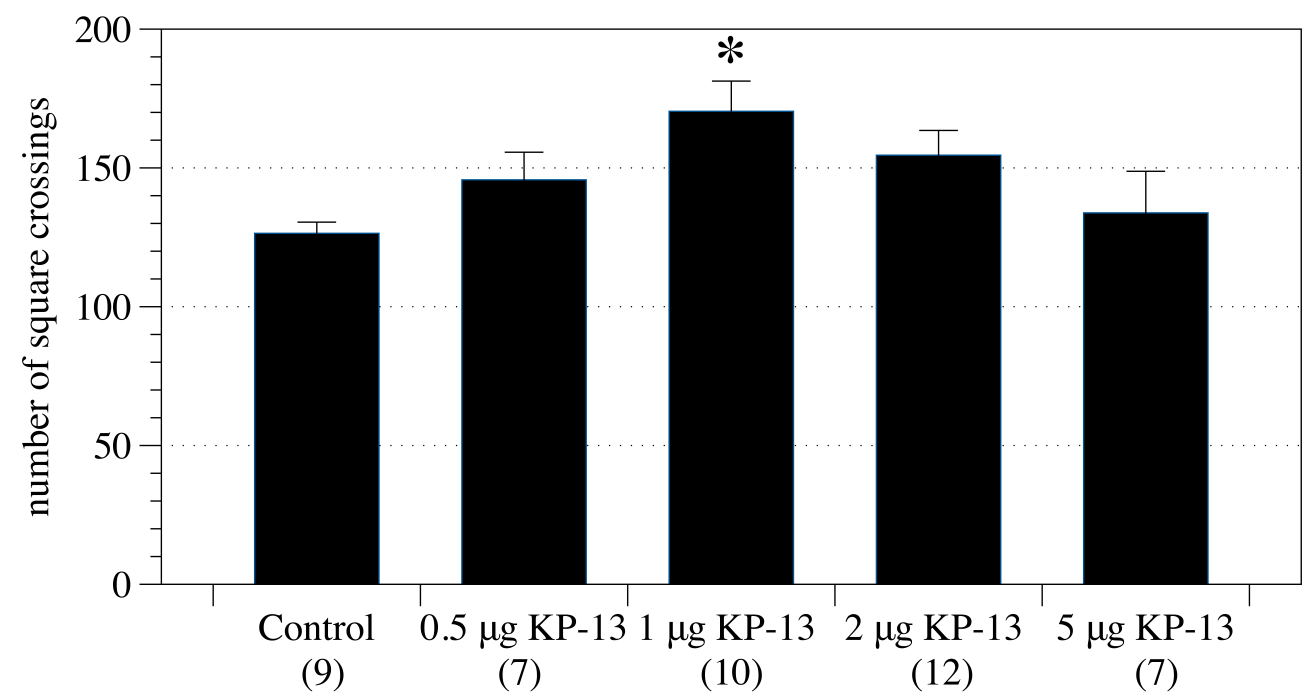

Figure 10: The effect of KP-13 on exploratory locomotor activity ${ }^{10}$

\subsubsection{Effect of KP-13 on Elevated Plus Maze Behaviour}

KP-13 reduced both the number of entries into $[\mathrm{F}(3,36)=7.095, \mathrm{p}<0.001]$ and the time spent $[\mathrm{F}(3,36)=3.298, \mathrm{p}<0.05]$ in the open arms (Figure 11), this action proving to be dose-dependent. A statistically significant change in the time spent in the open arms was caused by the $2 \mu \mathrm{g}$ dose of KP-13, while as concerns the number of entries into open arms, both the 1 and $2 \mu \mathrm{g}$ doses induced significant reductions. There was no difference in the number of total entries between the tested groups $[\mathrm{F}(3,36)=0.555, \mathrm{p}=0.648]$. AVP ANT per se $(0.1 \mu \mathrm{g} / 2 \mu \mathrm{l}$, icv. $)$ did not affect the EPM behaviour. In KP-13-treated rats, pretreatment with the AVP ANT partially reversed the KP-13-induced decrease in both time spent $[\mathrm{F}(3,29)=8.642, \mathrm{p}<0.05]$ and entries $[\mathrm{F}(3,29)=3.776, \mathrm{p}<0.05]$ into open arms (Figure 12). Kisspeptin-234

\footnotetext{
${ }^{9}$ Data are expressed as means. The pooled standard deviations (PSDs): 0.40 for the control, 0.49 for the $1 \mu \mathrm{g} \mathrm{KP}-13$ treated group, 0.52 for the $2 \mu \mathrm{g} \mathrm{KP}-13$ treated group. Numbers in parenthesis denote the number of animals used. ${ }^{*} \mathrm{p}<0.05$ vs. control.

${ }^{10}$ Mean and SEM are expressed. Numbers in parenthesis denote the number of animals used. * $\mathrm{p}<0.05$ vs. control.
} 
per se $(2 \mu \mathrm{g} / 2 \mu \mathrm{l}$, icv. $)$ did not affect the time spent in open arms, entries into open arms or total entries. In the KP-13-treated rats, pretreatment with kisspeptin-234 resulted in an increase the time spent $[\mathrm{F}(3,36)=20.791, \mathrm{p}<0.05]$ and the entries $[\mathrm{F}(3,36)=16.715, \mathrm{p}<0.05]$ into open arms (Figure 13).

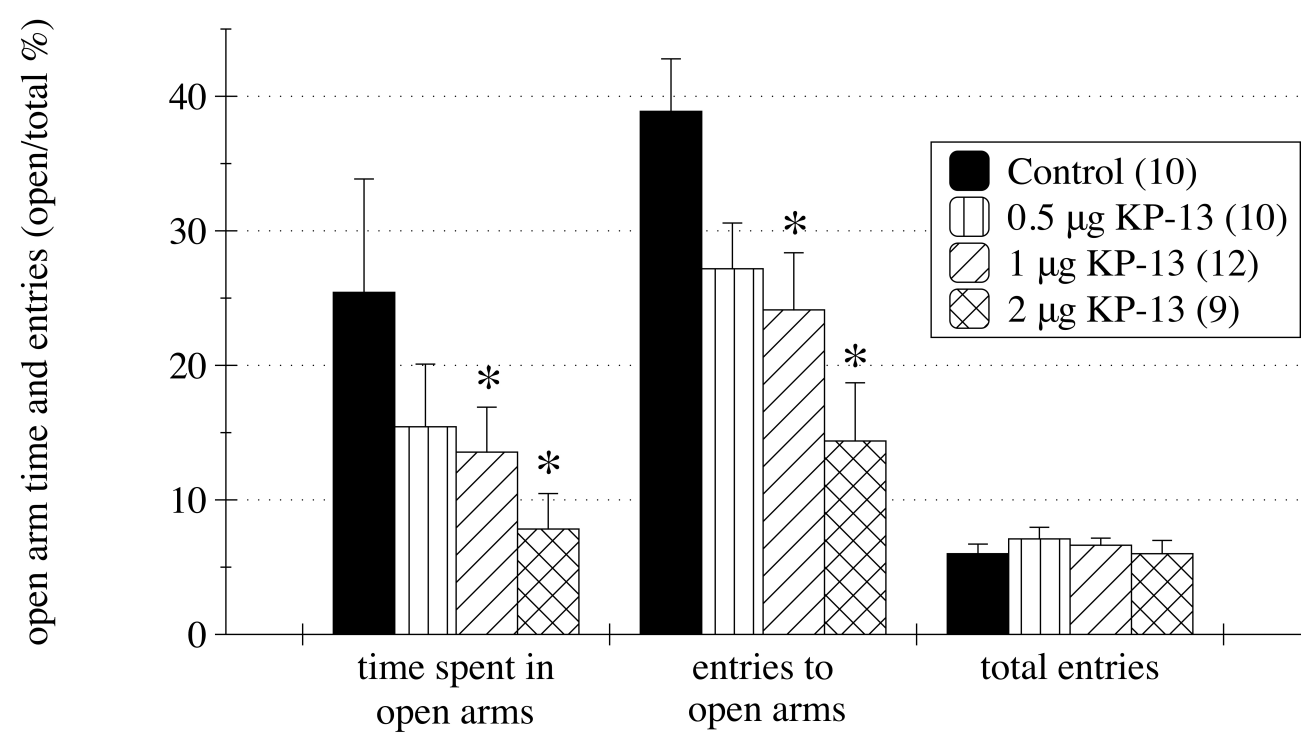

Figure 11: The effect of KP-13 on elevated plus maze behaviour ${ }^{11}$

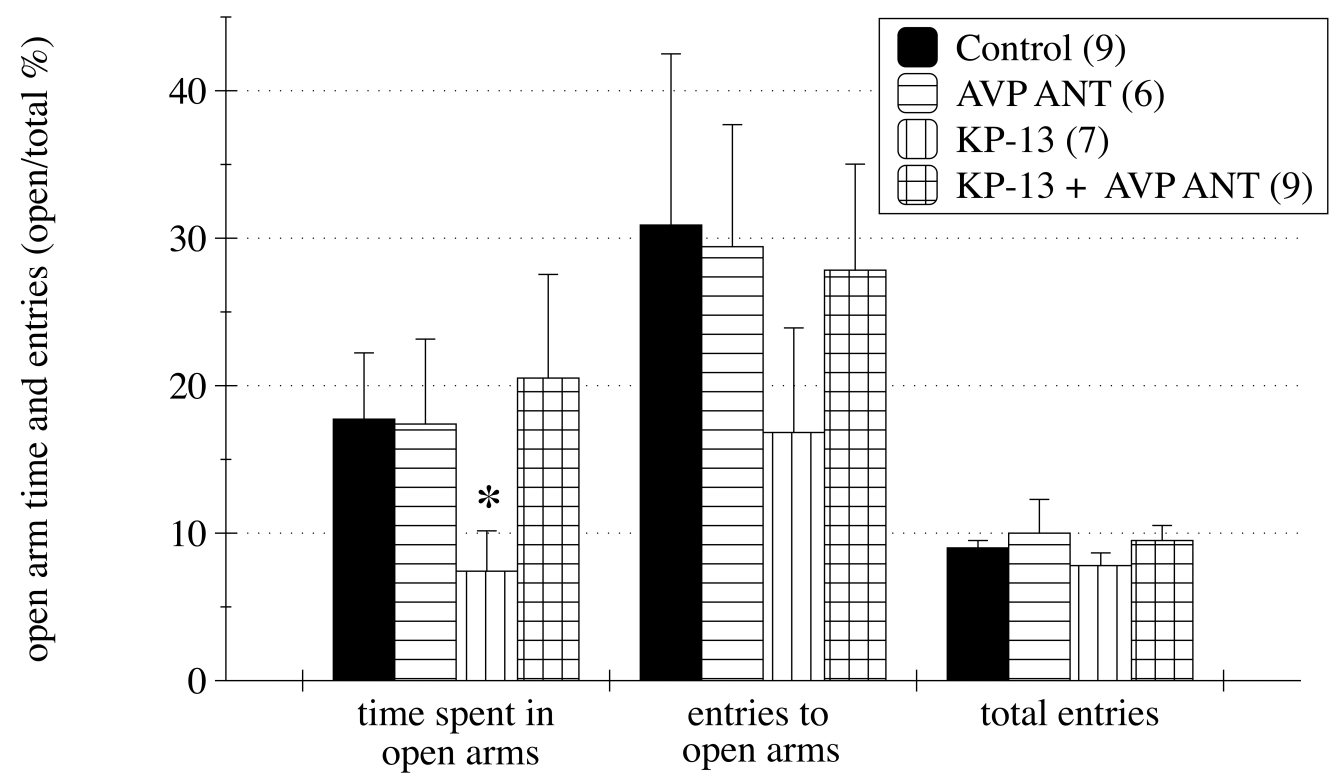

Figure 12: The effect of the AVP1R antagonist (AVP ANT) on KP-13-induced changes in elevated plus maze behaviour ${ }^{12}$

\footnotetext{
${ }^{11}$ Mean and SEM are expressed. Numbers in parenthesis denote the number of animals used. * $\mathrm{p}<0.05$ vs. control.
} 


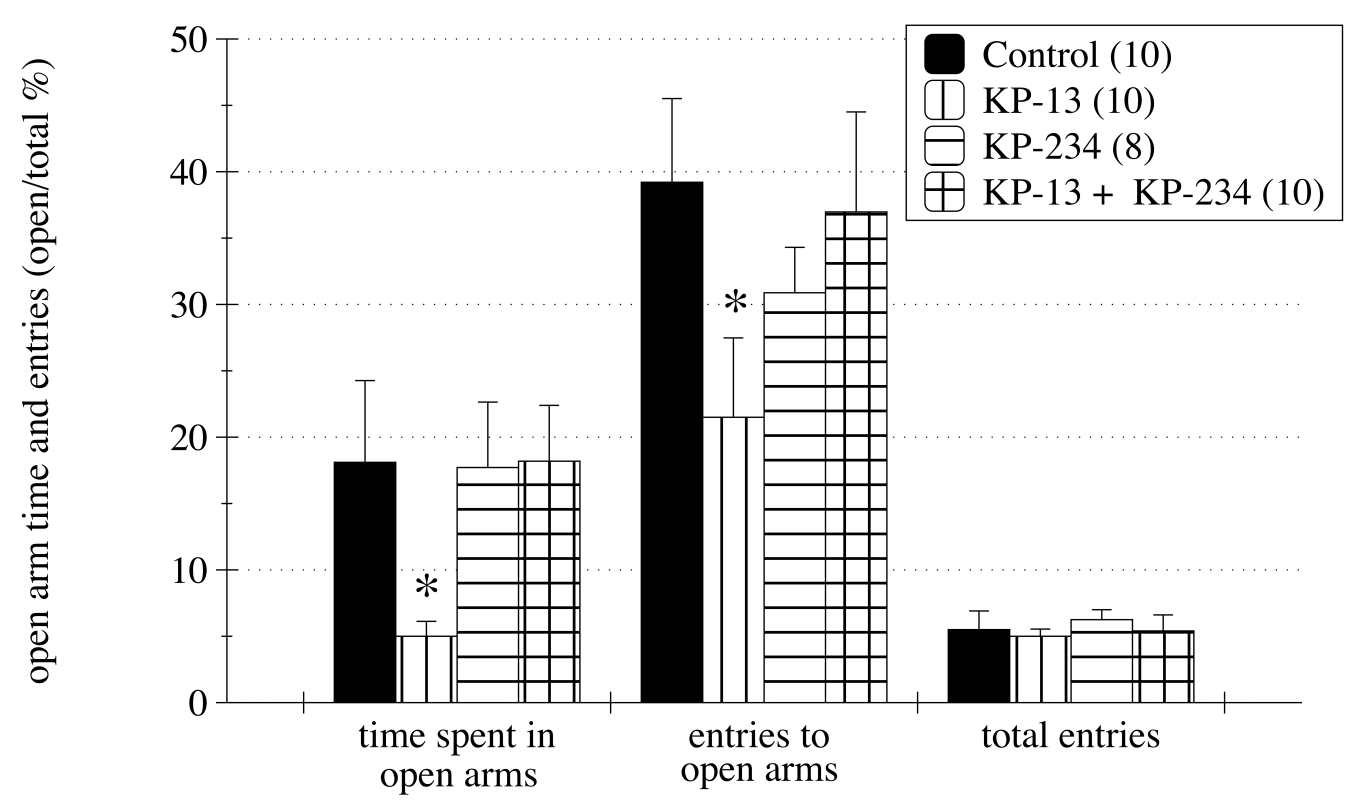

Figure 13: The effect of kisspeptin-234 on KP-13-induced changes in elevated plus maze behaviour 13

\subsection{Discussion}

In our experiments, KP-13 evoked an elevation of the corticosterone concentration. The most important activators of the HPA axis are CRH and AVP [182], secreted by the parvocellular part of the PVN. Rao et al. [180] recently reported that in PVN-derived cell lines KP-10 generated significant increases in AVP and oxytocin mRNA expression, whereas the CRH mRNA level was affected only at a high dose [180]. Thus, a possible explanation for our result is that KP-13 may stimulate the AVP-expressing neurones in the PVN, leading to activation of the HPA axis. In point of fact, our results with the AVP antagonist revealed that AVP secretion is necessary for kisspeptin-induced elevation of corticosterone. Furthermore, a recent study found that kisspeptins can bind to the NPFF2R [121]. Accordingly, in our previous experiments, NPAF, a potent NPFF2R ligand, also stimulated the HPA axis [79]. NPAF was most effective at the dose of $0.5 \mu \mathrm{g}$, whereas it was the 2 $\mu \mathrm{g}$ dose of KP-13 that elicited the greatest response. This might be explained by the differences in the affinity and the efficacy of the two peptides. There is also evidence pointing to the direct action of kisspeptin at the level of the pituitary. Kisspeptin has been detected in ovine hypophyseal portal blood [205] and KISS1R

\footnotetext{
${ }^{12}$ Mean and SEM are expressed. Numbers in parenthesis denote the number of animals used. * $\mathrm{p}<0.05$ vs. control, AVP ANT, KP-13 + AVP ANT.

${ }^{13}$ Mean and SEM are expressed. Numbers in parenthesis denote the number of animals used. * $\mathrm{p}<0.05$ vs. control, KP-234, KP-13 + KP-234.
} 
has also been found in the pituitary by RT-PCR [181], here co-localised with ACTH expressing cells [178]. However, it must be noted that Rao et al. [180] found that ip. administered KP-10 had no effect on corticosterone secretion in mice. Recent publications have also revealed that the activity of KP-10 is strongly dependent on the route of administration: central injection of KP-10 inhibited food intake, whereas ip. administration did not influence it in mice [208]. Additionally, Scott and Brown [192] found KP-10 to be effective in increasing the firing rate of oxytocin neurones on intravenous injection, but not on icv. administration. It is possible that kisspeptin, like the vast majority of neuropeptides, cannot cross the blood-brain barrier or does not reach the neuroendocrine regions relevant to the HPA axis in sufficient concentration due to enzymatic degradation [172]. These pharmacokinetic problems can clearly be circumvented by properly designed analogs [44]. Another explanation for the discrepancy between our results and that of Rao et al. [180] might be the use of KP-13 in our experiments instead of KP-10. Lyubimov et al. [121] reported that the NPFF2R binding of kisspeptins depends on the length of the peptide and the presence of the amidated C-terminal dipeptide. KP-13, therefore, proved to be a more potent activator of NPFF2R then KP-10 [121].

Our results demonstrate that kisspeptin can influence the behaviour of rats. OF and telemetric observations revealed that the icv. injection of KP-13 caused a marked activation of novelty-induced and spontaneous locomotion. Increasing doses of KP-13 exhibited a bell-shaped dose-response curve. This type of response is well-known in the literature and has been described in case of other neuropeptides [146, 22]. Since KISS1R has been found abundantly in locomotor centres of key importance such as the striatum and Amy [148, 98, 106], therefore it is plausible that KP-13 stimulated these regions directly.

Furthermore, KP-13 evoked a preference for the closed arms in the EPM test, which is indicative of an anxiogenic action of KP-13 in rats. This reinforces our finding that KP-13 activated the HPA axis, as both CRH [97] and AVP [156] are potent activators of stress-related behaviour. In our experiments, pretreatment with an AVP1R antagonist diminished the anxiogenic actions of KP-13, which suggests that central AVP release might be responsible for this effect. NPAF in a previous study showed a similar anxiety-like behaviour, which is possibly mediated by the NPFF2Rs. As KP-13 might be a potent activator of NPFF2R as well, these data raise the issue if the observed effect of KP-13 is mediated through its cognate receptor, KISS1R or the NPFF2R. To address this question we have pretreated the animals with kisspeptin-234, a potent KISS1R blocker and found that kisspeptin-234 abolished the anxiogenic action of KP-13. Hence, the effect of KP-13 on EPM may be mediated through KISS1R signalling rather then NPFF2R. In fact, the central Amy and the BNST, both of which have a pivotal role in generating negative emotional 
responses [39], receive input from kisspeptin neurons [106] and express KISS1Rs in abundance.

KP-13 induced a significant elevation of core temperature that persisted for several hours. An increased locomotor activity was also observed in these experiments, however, this lasted only an hour suggesting that it is not the cause of the detected changes in temperature. As kisspeptin is a well-known stimulator of GnRH [94, GnRH might mediate the hyperthermic action of KP-13, which would be in accord with the possible role of $\mathrm{GnRH}$ in thermoregulation, suggesting $\mathrm{GnRH}$ as a causative factor in hot flashes [115, 41]. Other possible explanation could involve the activation of hypothalamic prostaglandin synthesis, increased basal metabolic activity or the stimulation of the hypothalamus-pituitary-thyroid axis.

Considering the fact that kisspeptin's main role in the CNS is the regulation of the HPG axis our results seem contradictory as suppression of reproductive function in case of chronic stress is well documented in the literature [27, 110]. However, it must recognised that coordination of HPG activity with other CNS functions is indispensable, in which kisspeptin might play a crucial role. Indeed, kisspeptin recently had been implicated in the integration of metabolic signals with that of reproduction [17, 187]. Therefore, it is not a far-fetched idea that our results, in which KP-13 activated the HPA axis and associated behavioural paradigms, might reflect such an integrative role of kisspeptin. Furthermore, the role of the stress system in the body is defined as coping with any threat or actual damage to homeostasis (discussed in detail in Introduction), therefore, signals of all homeostatic functions must be forwarded to the PVN to adequately assess changes in the environment and to coordinate a sufficient response. Kisspeptin might be one of the signals that can relay changes in HPG activity, most specifically changes in cyclic activity. As a consequence, this signalling can be the afferent part of a well-tuned regulatory loop, the end result of which might be a rise in corticosterone secretion. In point of fact, in a recent publication corticosterone was found to inhibit Kiss1 mRNA expression in mice studies [93, which might make up the efferent part of this regulatory loop. Nevertheless, this is highly speculative as of yet and needs further investigation.

In conclusion, our results indicate that centrally injected KP-13 activates the HPA axis, induces hyperthermia and stimulates behavioural paradigms such as spontaneous and novelty-induced locomotion. Furthermore, KP-13 seems to generate anxiety-associated behaviour in adult rats. Our data confirm that RF-amide peptides belong to those neuropeptide families that have especially important role in neuroendocrine control. Notwithstanding, further investigations are necessary to clarify the mediation and signal transduction of the presented physiological phenomena, with special emphasis on the separation of the unique and overlapping features in the activity profile of the different RF-amides. 


\section{Kisspeptin Inhibits Depressive Behaviour in Mice}

\subsection{Introduction}

In the central nervous system, kisspeptin is transcribed within the hippocampal dentate gyrus [94]. In the present investigation, antidepressant-like effects of KP-13 were studied and the potential involvement of the adrenergic, serotonergic, cholinergic, dopaminergic and gabaergic receptors in its antidepressant- like effects was investigated in a modified FST in mice. Mice were pretreated with a non-selective $\alpha$-AR antagonist, phenoxybenzamine, an $\alpha_{1} / \alpha_{2} \beta$-AR antagonist, prazosin, an $\alpha_{2}$-AR antagonist, yohimbine, a $\beta$-AR antagonist, propranolol, a mixed $5-H T_{1} / 5-H T_{2}$ serotonergic receptor antagonist, methysergide, a nonselective $5-H T_{2}$ serotonergic receptor antagonist, cyproheptadine, a nonselective muscarinic acetylcholine receptor antagonist, atropine, a D2, D3, D4 dopamine receptor antagonist, haloperidol, or a GABA-A receptor antagonist, bicuculline.

\subsection{Materials and Methods}

\subsubsection{Animals}

CD1 (Charles Dawley) male mice were kept and handled during the experiments in accordance with the instructions of the University of Szeged Ethical Committee for the Protection of Animals in Research. Each animal was used in the experiments only once. The animals were six week old, weighed between 28 and $35 \mathrm{~g}$. They were housed in cages in a room maintained at constant temperature $\left(25 \pm 1^{\circ} \mathrm{C}\right)$ and on a 12-h dark - light cycle (lights on at 06:00 - 18:00 h) with free access to tap water and standard laboratory food. At least 1 week of recovery from surgery was allowed before the experiments.

\subsubsection{Surgery}

The mice were implanted with a cannula introduced into the right lateral brain ventricle in order to allow icv. administration. The polystyrene cannula was inserted stereotaxically into the ventricle at the coordinates $0.2 \mathrm{~mm}$ posterior, $0.2 \mathrm{~mm}$ lateral to the bregma, and $2.0 \mathrm{~mm}$ deep from the dural surface [167]. The cannula was secured with cyanoacrylate (Ferrobond) (Budapest, Hungary). The mice were allowed a minimum of 5 days to recover from surgery before any icv. administration.

\subsubsection{Treatments}

KP-13 was from Bachem (Basel, Switzerland); phenoxybenzamine hydrochloride from Smith Kline French (Herts, UK); prazosin hydrochloride and yohimbine hy- 
drochloride from Tocris (Cologne, Germany); propranolol hydrochloride from ICI Ltd. (Macclesfield, UK); methysergide hydrogenmaleate from Sandoz (Cologne, Germany); cyproheptadine hydrochloride from Tocris (Bristol, UK); atropine sulfate from EGYS (Budapest, Hungary); haloperidol from G. Richter (Budapest, Hungary); and bicuculline methiodide from Sandoz (Basel, Switzerland). KP-13 was lyophilized in a quantity of $10 \mu \mathrm{g}$ per ampoule and stored at $-20^{\circ} \mathrm{C}$ Immediately before the experiments, the KP-13 was dissolved in sterile pyrogen-free $0.9 \%$ saline and administered icv. via the cannula in a volume of $2 \mu \mathrm{l}$.

\subsubsection{Forced swimming test}

The mice were forced to swim individually in a glass cylinder $12 \mathrm{~cm}$ in diameter and $30 \mathrm{~cm}$ in height, filled with water to a height of $20 \mathrm{~cm}$. The temperature of the water was adjusted to $25 \pm 1^{\circ} \mathrm{C}$. The water was changed between the individual mice. A 15-min pretest session was followed $24 \mathrm{~h}$ later by a 5 -min test session. Phenoxybenzamine (2 mg/kg, ip.), prazosin $(62.5 \mu \mathrm{g} / \mathrm{kg}$, ip.), yohimbine $(5 \mathrm{mg} / \mathrm{kg}$, ip.), propranolol (5 mg/kg, ip.), methysergide (5 mg/kg, ip.), cyproheptadine (3 $\mathrm{mg} / \mathrm{kg}$, ip.), atropine (2 mg/kg, ip.), haloperidol (10 $\mu \mathrm{g} / \mathrm{kg}$, ip.) or bicuculline (2 $\mathrm{mg} / \mathrm{kg}$, ip.) was administered $1 \mathrm{~h}$ before the test session, followed $30 \mathrm{~min}$ later by $\mathrm{KP}-13(2.0 \mu \mathrm{g} / 2 \mu \mathrm{l}$, icv.). Physiological saline was used as vehicle control. A timesampling technique was applied to score the durations of climbing, swimming and immobility. Climbing time was measured when the mouse was participating in active vertical motion with its forelegs above the water level; swimming time was recorded when the mouse was moving horizontally on the surface of the water; and immobility time was registered when the mouse was in a upright position on the surface with its front paws together and making only those movements necessary to keep itself afloat.

\subsubsection{Statistical analysis}

Two-way ANOVA test was followed by Tukey's test for multiple comparisons with unequal cell size. Probability values of less than 0.05 were regarded as indicative of significant differences.

\subsection{Results}

\subsubsection{Effect of KP-13 on forced swimming test}

Relative to the control, both the $1 \mu \mathrm{g}$ and $2 \mu \mathrm{g}$ dose of KP-13 significantly decreased the immobility time $[\mathrm{F}(3,35)=14.98: \mathrm{p}<0.05]$, significantly increased the climbing time $[\mathrm{F}(3,35)=7.75: \mathrm{p}<0.05]$ and swimming time $[\mathrm{F}(3,35)=11.10: \mathrm{p}<0.05]$. The most effective dose of KP-13 proved to be the $2 \mu \mathrm{g}$ dose (Figure 14). 


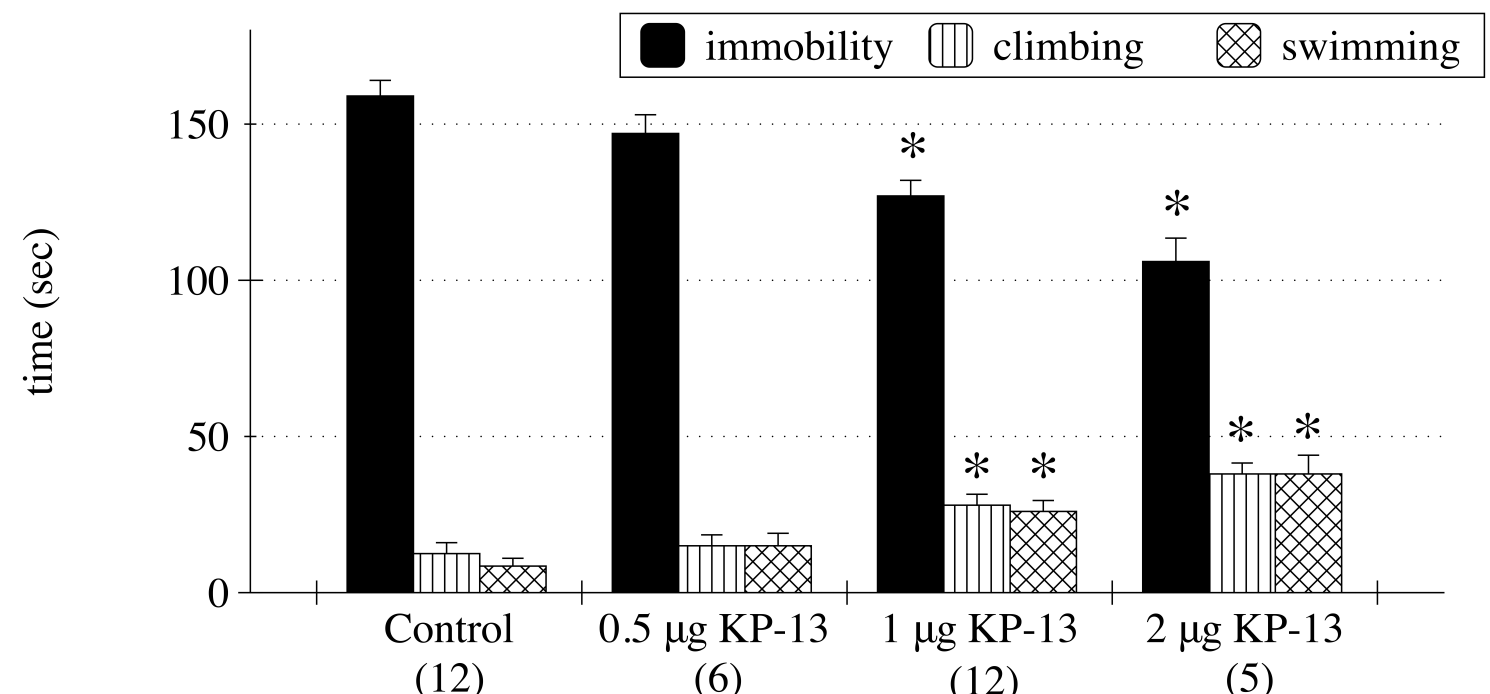

Figure 14: The effect of KP-13 on depressive behaviour in the modified mouse forced swim test (FST) ${ }^{14}$

\subsubsection{Effect of Antagonist Treatments on the KP-13-Induced Anti de- pressive Behaviour}

Phenoxybenzamine per se $(2 \mathrm{mg} / \mathrm{kg}$, ip.) did not affect the immobility time, climbing time or swimming time. In KP-13 treated mice, pretreatment with phenoxybenzamine partially reversed the KP-13- induced change in the immobility time, and decreased the changes in the climbing and swimming times (Figure 15). Prazosin per se $(62.5 \mu \mathrm{g} / \mathrm{kg}$, ip.) did not affect the immobility time, the climbing time or the swimming time. In the KP-13 treated mice, pretreatment with prazosin did not reverse the KP-13-induced changes in the immobility time, the climbing time or the swimming time (data not shown). Yohimbine per se $(5 \mathrm{mg} / \mathrm{kg}$, ip.) did not affect the immobility time, the climbing time or the swimming time. In KP-13-treated mice, pretreatment with yohimbine partially reversed the immobility time, the climbing time and the swimming time (Figure 16). Methysergide per se (5 mg/kg, ip.) did not affect the immobility time, the climbing time or the swimming time. In the KP-13 treated mice, pretreatment with methysergide did not reverse the immobility time, the climbing time or the swimming time (data not shown). Cyproheptadine per se $(3 \mathrm{mg} / \mathrm{kg}$, ip.) did not affect the immobility time, the climbing time or the swimming time. In the KP-13-treated mice, pretreatment with cyproheptadine resulted in an increased immobility time and decreased the changes in the climbing and

\footnotetext{
${ }^{14}$ Mean and SEM are expressed. Numbers in parenthesis denote the number of animals used. * $\mathrm{p}<0.05$ vs. control.
} 
swimming times (Figure 17). Propranolol per se $(5 \mathrm{mg} / \mathrm{kg}$, ip.) did not affect the immobility time, the climbing time or the swimming time. In the KP-13 treated mice, pretreatment with propranolol did not lead to an increase in the immobility time, and did not affect the climbing time or the swimming time (data not shown). Atropine per se $(2 \mathrm{mg} / \mathrm{kg}$, ip.) did not affect the immobility time, the climbing time or the swimming time. In the KP-13 treated mice, pretreatment with atropine did not affect the increased immobility time or the decreased climbing and swimming times (data not shown). Haloperidol per se $(10 \mu \mathrm{g} / \mathrm{kg}$, ip.) did not affect the immobility time, the climbing time or the swimming time. In the KP-13-treated mice, pretreatment with haloperidol did not increase the immobility time, nor affect the climbing or swimming times (data not shown). Bicuculline per se $(2 \mathrm{mg} / \mathrm{kg}$, ip.) did not affect the immobility time, the climbing time or the swimming time. In the KP-13 treated mice, pretreatment with bicuculline did not increase the immobility time, the climbing time or the swimming time (data not shown).

The above results reveal that the antidepressant-like effects of KP-13 in this modified mouse FST are mediated, at least in part, by $\alpha_{2}$-ARs and $5-H T_{2}$ serotonergic receptors.

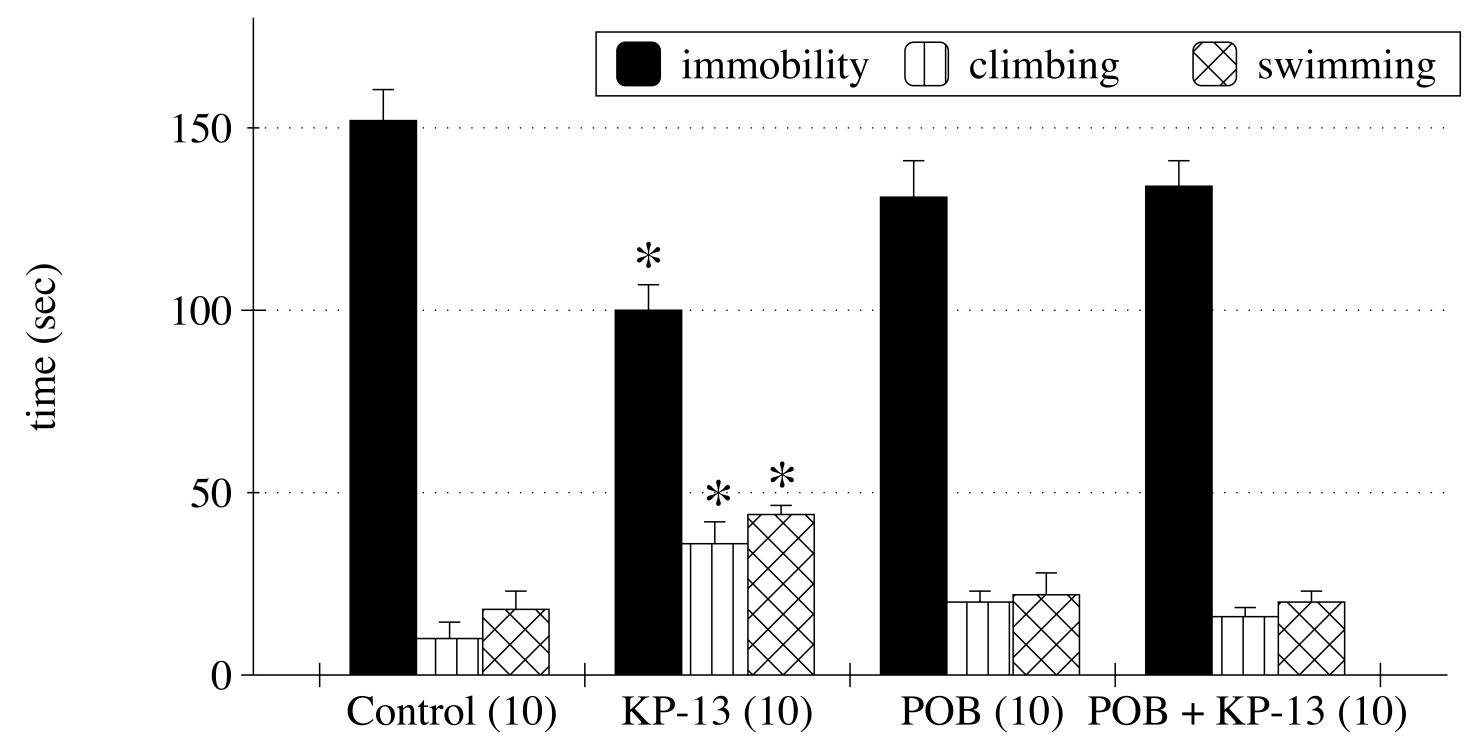

Figure 15: The effect of a nonselective $\alpha$-adrenergic receptor antagonist, phenoxybenzamine (POB) on KP-13-induced antidepressant-like action in modified mouse forced swim test (FST) ${ }^{15}$

\footnotetext{
${ }^{15}$ Mean and SEM are expressed. Numbers in parenthesis denote the number of animals used. * $\mathrm{p}<0.05$ vs. control, POB, POB $+\mathrm{KP}-13$.
} 


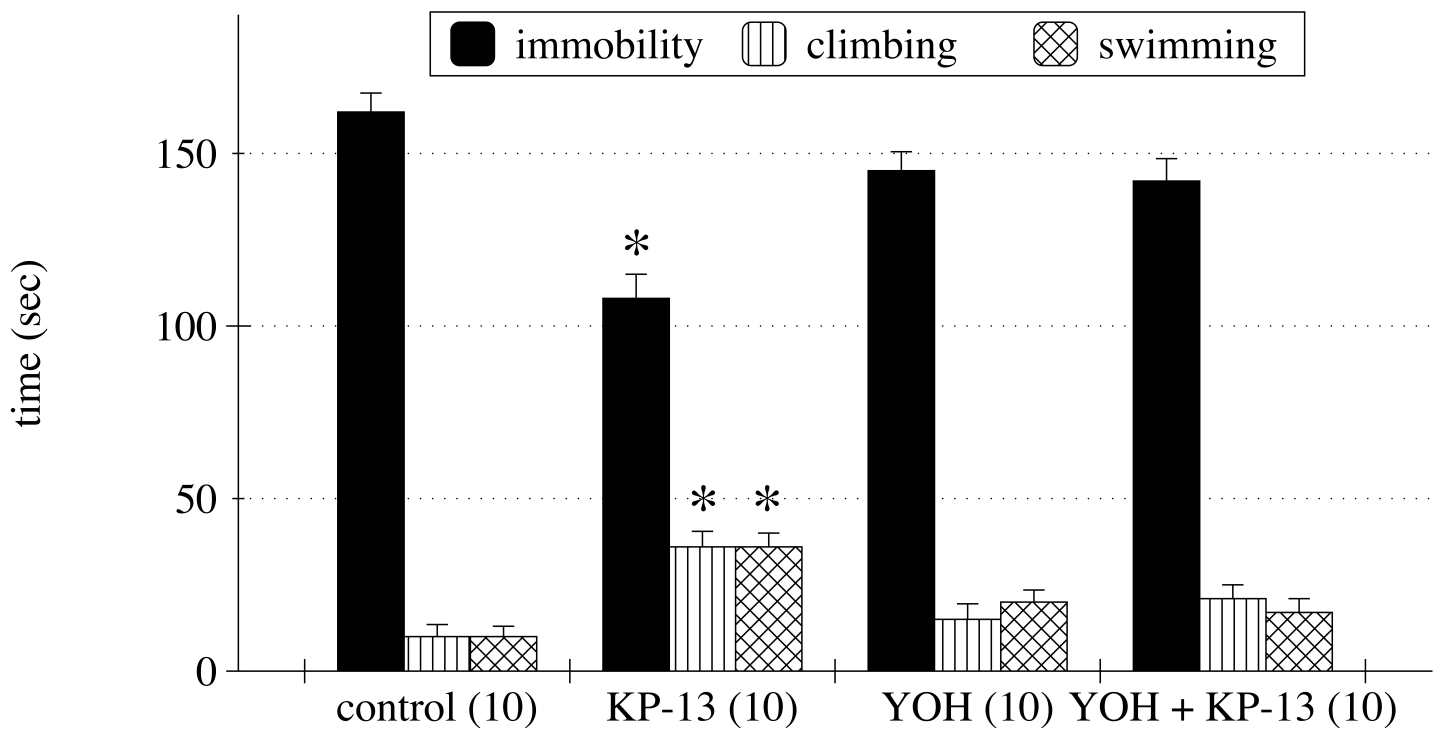

Figure 16: The effect of a nonselective $\alpha$-adrenergic receptor antagonist, yohimbine (YOH) on KP-13-induced antidepressant-like action in modified mouse forced swim test (FST) 16

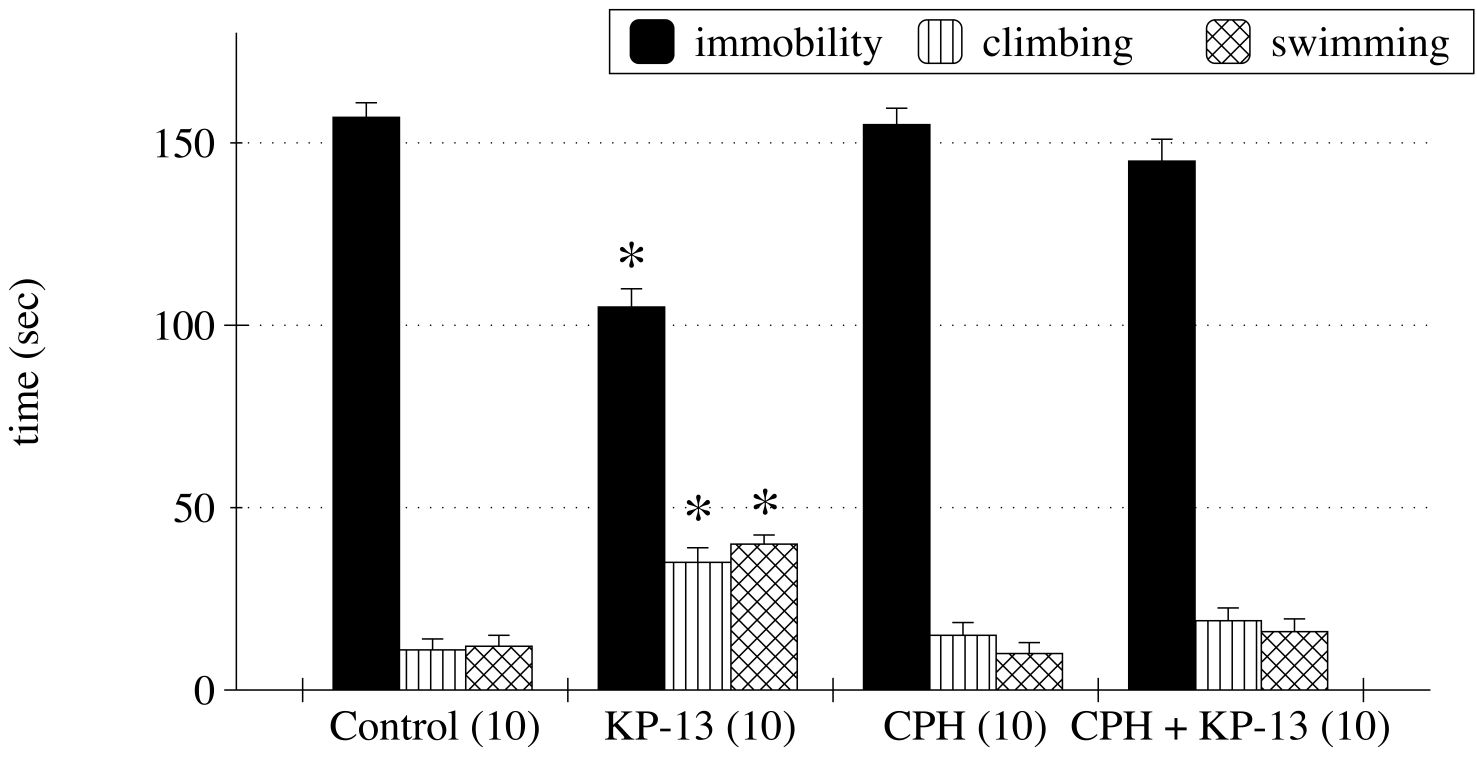

Figure 17: The effect of a nonselective $5-H T_{2}$ serotonergic receptor antagonist, cyproheptadine $(\mathrm{CPH})$ on $\mathrm{KP}-13$-induced antidepressant-like action in modified mouse forced swim test (FST) ${ }^{17}$

\footnotetext{
${ }^{16}$ Mean and SEM are expressed. Numbers in parenthesis denote the number of animals used. * $\mathrm{p}<0.05$ vs. control, $\mathrm{YOH}, \mathrm{YOH}+\mathrm{KP}-13$.

${ }^{17}$ Mean and SEM are expressed. Numbers in parenthesis denote the number of animals used. * $\mathrm{p}<0.05$ vs. control, $\mathrm{CPH}, \mathrm{CPH}+\mathrm{KP}-13$.
} 


\subsection{Discussion}

Our results showed that KP-13 have an anti-depressant like effect in the modified FST. Kisspeptin predominantly is expressed in brain regions that subserve circadian regulation of the reproductive axis and possibly the integration of the HPG system with other homeostatic systems [31, 20]. Icv. administration of kisspeptin results in a robust increase in LH secretion and less prominent FSH release that ultimately leads to the activation of the HPG axis [62, 1]. Taking this in account together with the possible role of $\mathrm{GnRH}$ in mood disorder pathologies [15, 132] it is plausible that kisspeptin exerts its effect through GnRH release. Additionally, a previous publication reported that kisspeptin increases the firing rate of oxytocin neurones [192], which could also explain the anti-depressant effect of kisspeptin as oxytocin has a well known anxiolytic action in the brain [80]. However, in the light of our previous data, in which kisspeptin activates the HPA axis and exerts anxiogenic behaviour in rats, our results in the present experiments are quite contradictory. The reason behind this discrepancy might be that the experiments were preformed in different species. In rats we have observed a clearly increased production of corticosterone and anxious behaviour, on the other hand, in mice kisspeptin was unable to provoke an elevation in corticosterone level (our unpublished data). This suggests species difference at a functional level. Furthermore, KISS1R distribution in mice is confined to GnRH neurones in the periventricular region of the hypothalamus and the dentate gyrus of the hippocampus, but not expressed in the rostral part of the hypothalamus [31, 72]. In contrast, rat brain expression studies showed a wider expression pattern for the KISS1R, which includes other hypothalamic nuclei and the pituitary as well [106, 20]. Considering these data, it is possible that the different expression patterns of KISS1R in these species are responsible for the contrast in kisspeptin actions in our studies. This concept also supports the idea that kisspeptin's effect on anxiety in rats might be mediated by the release of CRH and/or AVP in brain regions relevant to mood. Nevertheless, further experiments are needed to clarify the possible involvement of other neuropeptides in kisspeptin's action.

To clarify the mechanism of the antidepressant-like actions of KP-13, various receptor blockers were administered before icv. injection of KP-13. The receptor blocker doses were selected so that the blockers per se were ineffective, but were able to block the action of a neuropeptide as described in a previous study [158]. The observation made with the receptor blockers indicated that the action of KP-13 is mediated by certain receptors. The nonselective $\alpha$-AR antagonist phenoxybenzamine, the $\alpha_{2}$-AR antagonist yohimbine and the nonselective $5-H T_{2}$ serotonergic receptor antagonist cyproheptadine prevented the effects of KP-13 on the immobility, climbing and swimming times. The $\alpha_{1} / \beta$-AR antagonist prazosin, the $\beta$-AR blocker propran- 
olol, the mixed $5-H T_{1} / 5-H T_{2}$ serotonergic receptor antagonist methysergide, the nonselective muscarinic acetylcholine receptor antagonist atropine, the D2, D3, D4 dopamine receptor antagonist haloperidol and the GABA-A receptor antagonist bicuculline had no effect on KP-13 induced anti-depressive behaviour.

Almost five decades ago was the classical monoamine hypothesis proposed to explain the therapeutical efficacy of the first anti-depressive medications such as the tricyclic antidepressants and the monoamine oxidase inhibitors, both of which were known to increase norepinephrine and serotonin levels in the brain [191, 9]. Since then a great body of literature accumulated on the subject, however with mixed results, leading to the realisation that the original hypothesis cannot answer for the emerging evidence on the complexity and heterogenicity of depression-related neurobiology [75]. Nevertheless, even as it is, as of yet, unclear if the dysfunction of the monoamine systems is a consequence or in fact a causative factor in the pathogenesis of depression, it unarguably contributes to and exacerbates the pathological changes. The central noradrenergic system is based in a brainstem nucleus known as locus coeruleus, which through noradrenergic projections reach almost all brain areas and thus influence multiple brain functions [9, 189]. Noradrenaline released in the synapse exerts its effect through GPCRs known as ARs [33]. $\alpha_{2}$-ARs are found predominantly in the CNS, and of the several subtypes, the $\alpha_{2 A^{-}} \mathrm{AR}$ and $\alpha_{2 C^{-}} \mathrm{AR}$ are implicated in depressive behaviour [33. In our results KP-13 evoked an anti-depressive behaviour in the FST, which was inhibited by the non selective $\alpha$-AR and the selective $\alpha_{2}$-AR blockers, whereas the $\alpha_{1} / \beta$-AR antagonist was not effective. These results suggest that KP-13's action is mediated by noradrenaline release and possibly $\alpha_{2 A}$-AR or $\alpha_{2 C^{-}} \mathrm{AR}$ activation. This is in accord with previous findings that indicate that $\alpha_{2 A^{-}}$ AR agonists through the reduction in locus coeruleus firing activity compensate for the depletion of noradrenaline levels [164], which is characteristic in depressive disorders. Of the two subtypes of ARs, $\alpha_{2 A}$-AR seems to be more likely the culprit as studies using knockout models for the two subtypes suggest opposing roles for them in FST: $\alpha_{2 A^{-}}$AR mediating anti depressive effect [165], whereas $\alpha_{2 C^{-}} \mathrm{AR}$ activation leads to depressive phenotype [166]. However, it must be noted that there are some discrepancies in the subtype-selective studies which is possibly due to the scarcity of them and to differences in methodology [33. Nevertheless, our result indicate an interaction between KP-13 and noradrenalin transmission, the how and where is yet to be explored.

The anti depressive effect of KP-13 was also blunted by the $5-H T_{2}$ receptor blocker. This suggests that serotonin neurotransmission mediated by $5-H T_{2}$ receptors might be involved in KP-13's actions in the FST. The role of the serotonin system in depression is well known as evidenced by pharmacological and clinical observations that enhancement of serotonin function alleviates depression [116], how- 
ever, the mechanism behind it is not well understood. Our results implicate $5-H T_{2}$ receptors to be involved in mediating kisspeptin's effect, which is in accord with literature data. There are multiple $5-H T_{2}$ receptors, of which both $5-H T_{2 A}$ and $5-H T_{2 C}$ could mediate the effect of KP-13 on depressive behaviour supported by, first, increased $5-H T_{2 A}$ expression in the cortex have been found in patients with depression or with depression-related personality traits [139, 197]. Second, selective $5-H T_{2 A}$ antagonists have been reported to produce anti depressive effects in FST, sucrose preference test, social interaction test and open field exploration [166, 164], third, co-administration with selective serotonin re-uptake inhibitors (SSRIs) $5-H T_{2 A}$ antagonists augment the effect of SSRIs [125]. On the other hand, $5-H T_{2 C}$ is expressed in distinct brain regions such as the amygdala, hippocampus and the substantial nigra among others [68] and both $5-H T_{2 C}$ agonists and antagonists were found to exhibit antidepressant actions in animal models of depression [35, 40, 45]. This discrepancy in the behavioural outcomes of the $5-H T_{2 C}$ agonist and antagonist treatments might be explained by different mechanisms of action where agonists exert their effect directly, whereas antagonists might act indirectly through interaction with the dopaminergic and/or noradrenergic systems [23]. To determine the exact mechanism behind the effect of kisspeptin on depressive behaviour further experiments are needed.

In conclusion, our results indicate that KP-13 induces anti-depressive behaviour in mice, which effect might come about, at least in part, by the interaction of $\alpha_{2}{ }^{-}$ adrenergic and $5-H T_{2}$ serotonergic receptors. 


\section{Kisspeptin Modulates Pain Sensation in Mice}

\subsection{Introduction}

Kisspeptin is a member of the RF-amide family, which have been previously implicated in nociception control [56]. NPFF and analogues were found to have analgesic, pronociceptive and antinociceptive, and furthermore morphine modulating activities. Evidence suggests that these effects are mediated by the activation of NPFF1R and NPFF2R receptors, respectively [102, 165]. Additionally, all endogenous RFamide peptides seem to target not only their cognate receptors, but the NPFF1R and NPFF2R receptors as well, which argue for their role in pain modulation [50]. Although much evidence has accumulated in the past couple of years that ascribes a critical role for the NPFF1R and NPFF2R receptors for the pain-modulating effects of RF-amide peptides, however, recent distribution data draws attention to other receptors, such as KISS1R and GPR10, and their endogenous ligands that are expressed in several brain areas involved in the control of pain [104]. For instance, both KISS1R and kisspeptin mRNAs and proteins have been detected in the dorsal horn of the spinal cord and in the dorsal root ganglia in rats [47, 140].

Therefore, in the present study we investigated the possible interaction of kisspeptin with the acute effects of morphine on nociception and the potential involvement of kisspeptin in acute morphine tolerance and withdrawal in adult male CFLP mice.

\subsection{Materials and methods}

\subsubsection{Animals}

Male CFLP white mice ( $30 \pm 5 \mathrm{~g}$ of weight) of an outbred strain (Domaszék, Hungary) were used. They were kept under a standard light - dark cycle (lights on between 07.00 and $19.00 \mathrm{~h}$ ) with food and water available ad libitum. The animals were kept and treated according to the rules of the Ethical Committee for the Protection of Animals in Research (Faculty of Medicine, University of Szeged, Hungary).

\subsubsection{Surgery}

For icv. cannulation, the mice were anaesthetised with an ip. injection of Sodium Pentobarbital (Euthasol, Phylaxia-Sanofi, Budapest, Hungary; $50 \mathrm{mg} / \mathrm{kg}$ ), and a polyethylene cannula was inserted into the right lateral cerebral ventricle and cemented to the skull with cyanoacrylate-containing instant glue. The experiments were started 4 days after icv. cannulation. Upon conclusion of the experiments, $10 \mu \mathrm{l}$ of methylene blue were injected into the cerebral ventricle of the decapitated animals and the position of the cannula was inspected visually. The spread of methylene blue 
throughout the ventricular space indicated that the whole amount of kisspeptin got into the ventricles. Mice with improper cannula placement were excluded from the final statistical analysis.

\subsubsection{Treatments}

Mice were injected with different doses of KP-13 (Bachem Ltd., Switzerland) icv. in a volume of $2 \mu \mathrm{l}$ over $30 \mathrm{~s}$ with a Hamilton microsyringe, immobilization of the animals being avoided during handling. The doses applied were $0.5,1$, or $2 \mu \mathrm{g}$ dissolved in $0.9 \%$ saline. For experiments testing the effect of morphine, subcutan (sc.) morphine $\mathrm{HCl}$ (Sigma-Aldrich) and naloxone $\mathrm{HCl}$ (Sigma-Aldrich) injections were used. Control animals received saline alone.

\subsubsection{Tail-Flick test}

Kisspeptin effect on morphine-evoked analgesic response was tested by the tail-flick system (IITC Life Science, California, USA) described by [36]. All experiments were started with an initial tail-flick latency measurement, then pain sensitivity was measured 15, 30, and 60 min after peptide challenge in acute dose-response experiments and 60, 90, and 120 min after the test morphine treatment. For tail-flick measurement, animals were habituated to the experimental room at least 30 min prior to testing. During the measurement, they were loosely restrained and the tail was positioned so that the light beam focused on the tail approximately 1-2 $\mathrm{cm}$ from the base. Tail stimulation was delivered at different sites in consecutive measures to prevent tissue damage. The analgesic effect was expressed according to following equation:

analgesic effect $(\%)=(T F n-T F 0) /(T F \max -T F 0) x 100$,

where TF0 is the tail-flick latency in the preliminary test mentioned above or (in tolerance studies) before morphine injection. TFn is the value of a repeated corresponding measurement $\mathrm{n}(15,30,60$ or $60,90,120 \mathrm{~min})$ after KP-13 or/and morphine injection, and TFmax indicates the cutoff (20 s).

The following experiments were carried out: The effect of KP-13 on pain sensitivity were measured. In experiments with KP-13 on the acute antinociceptive effect of a single dose of morphine, the peptide was administered $30 \mathrm{~min}$ prior to the test dose of morphine $(2.4 \mathrm{mg} / \mathrm{kg} \mathrm{sc}$.), and the pain sensitivity was measured 30 and 60 min later. In acute tolerance studies, animals were pretreated with KP-13 and 60 min later a tolerance-inducing dose of morphine $(60 \mathrm{mg} / \mathrm{kg} \mathrm{sc}$.) was administered, $24 \mathrm{~h}$ after of which a test dose of morphine (4 mg/ $\mathrm{kg} \mathrm{sc}$.) were injected to assess the antinociceptive effect. In acute withdrawal studies, 30 min after KP-13 pretreatment 
a tolerance-inducing dose of morphine $(60 \mathrm{mg} / \mathrm{kg})$ was administered, $3 \mathrm{~h}$ after of morphine injection animals received naloxone to precipitate withdrawal signs. The precipitated abstinence syndrome was assessed by scoring the latency of the stereotyped jumping from a circular platform with a diameter of $35 \mathrm{~cm}$ placed $70 \mathrm{~cm}$ high. A cut-off time of $900 \mathrm{~s}$ was applied. Meanwhile, body temperature and weight of the animals were measured before naloxone treatment, $15 \mathrm{~min}, 30 \mathrm{~min}$ and $60 \mathrm{~min}$ after, of which the changes were calculated.

\subsubsection{Statistical Analysis}

Data are presented as means \pm SEM. Statistical analysis of the results was performed by ANOVA. For the effect of KP-13 on pain sensitivity and jumping latency in the acute withdrawal study one-way ANOVA was employed, followed by the Holm-Sidak post hoc test for multiple comparisons when the test prerequisites were fulfilled. When the test of the homogeneity of variances was not satisfied, nonparametric ANOVA on ranks (Kruskal-Wallis) was performed, followed by Dunn's test for multiple comparisons. For the evaluation of the tail flick, weight and temperature recordings with combined treatments two-way ANOVA was performed followed by Holm-Sidak test for multiple comparisons. A probability level of less then 0.05 was accepted as indicating a statistically significant difference.

\subsection{Results}

\subsubsection{Effect of KP-13 on Tail-Flick Latency}

Icv. injection of KP-13 dose dependently decreased the tail-flick latency of CFLP mice, of the different doses applied the $1 \mu \mathrm{g}$ proved to be the most effective (Figure 18). The action of kisspeptin on nociception was observed both $30[\mathrm{~F}(3,36)=6.04$, $* \mathrm{p}<0.05]$ and $60 \min \left[\mathrm{H}=8.139,{ }^{*} \mathrm{p}<0.05\right]$ after peptide administration. 


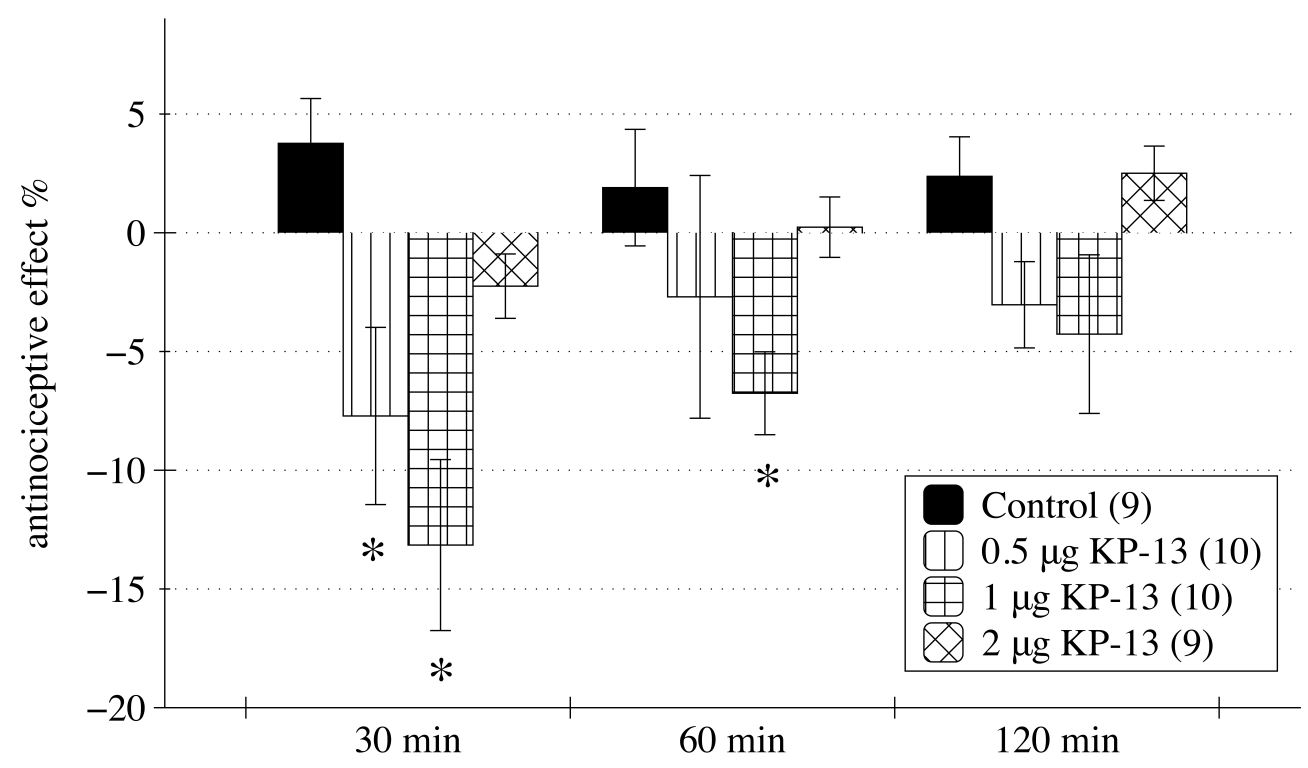

Figure 18: The effect of KP-13 on pain sensitivity in the tail-flick test ${ }^{18}$

\subsubsection{Effect of KP-13 on Challenge Dose of Morphine}

A single dose of $2.4 \mathrm{mg} / \mathrm{kg} \mathrm{sc}$. morphine induced an appr. $80 \%$ analgesia. KP-13 in a $1 \mu \mathrm{g}$ dose significantly lowered the analgesic effect of morphine $30[\mathrm{H}=34.850, \mathrm{p}$ $<0.05]$ and $60 \min [\mathrm{F}(3,26)=45.604, \mathrm{p}<0.05]$ after the narcotic challenge (Figure 19).

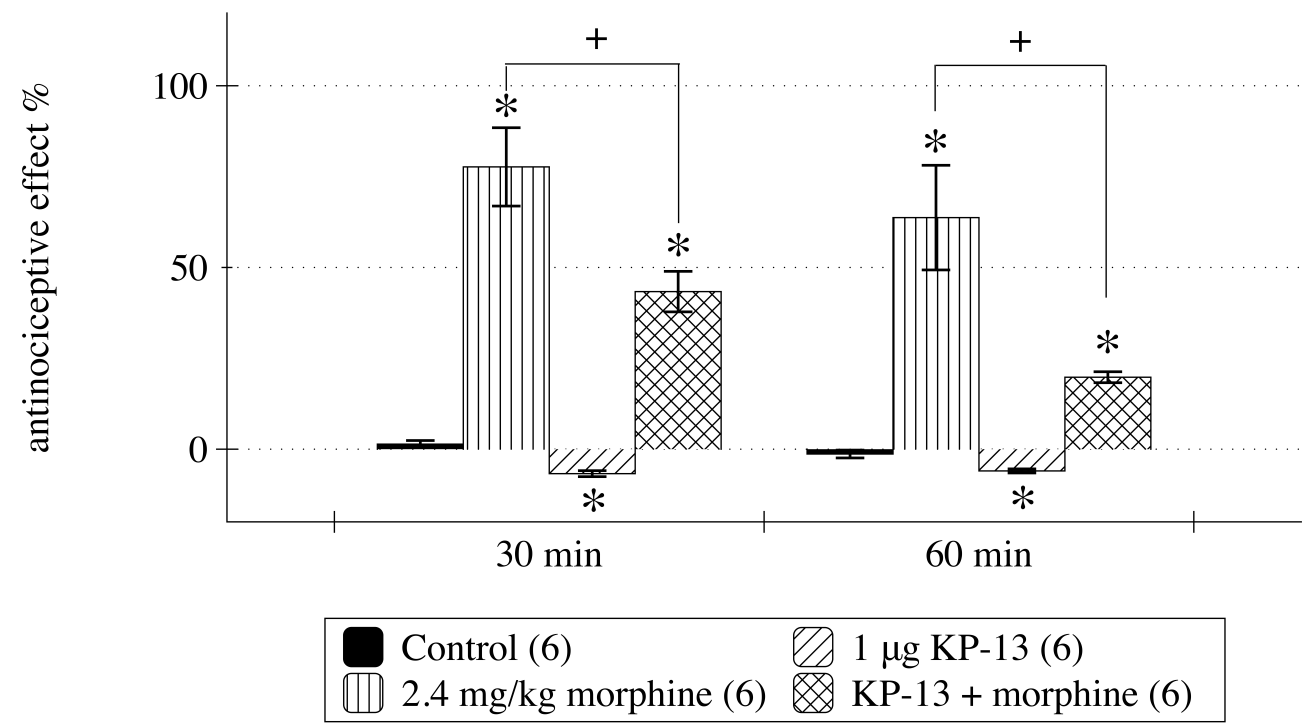

Figure 19: The effect of KP-13 on morphine-induced analgesia in the tail-flick test ${ }^{19}$

\footnotetext{
${ }^{18}$ Mean and SEM are expressed. Numbers in parenthesis denote the number of animals used. * $\mathrm{p}<0.05$ vs. control.
} 


\subsubsection{Effect of KP-13 on Acute Morphine Tolerance}

Acute tolerance was observed $24 \mathrm{~h}$ after a tolerance inducing dose of morphine was applied sc. Our results showed that KP-13 treatment 30 min before tolerance induction prevents the development of acute morphine tolerance. The KP-13-treated animals that received the tolerance inducing dose of morphine showed a significantly higher antinociceptive effect then tolerant animals both $30 \mathrm{~min}[\mathrm{~F}(3,22)=78.333$, $\mathrm{p}$ $<0.05], 60 \min [\mathrm{F}(3,22)=28.853, \mathrm{p}<0.05]$ and $120 \min [\mathrm{F}(3,22)=13.188, \mathrm{p}<$ 0.05] after injection of the $4 \mathrm{mg} / \mathrm{kg}$ sc. test dose of morphine (Figure 20).

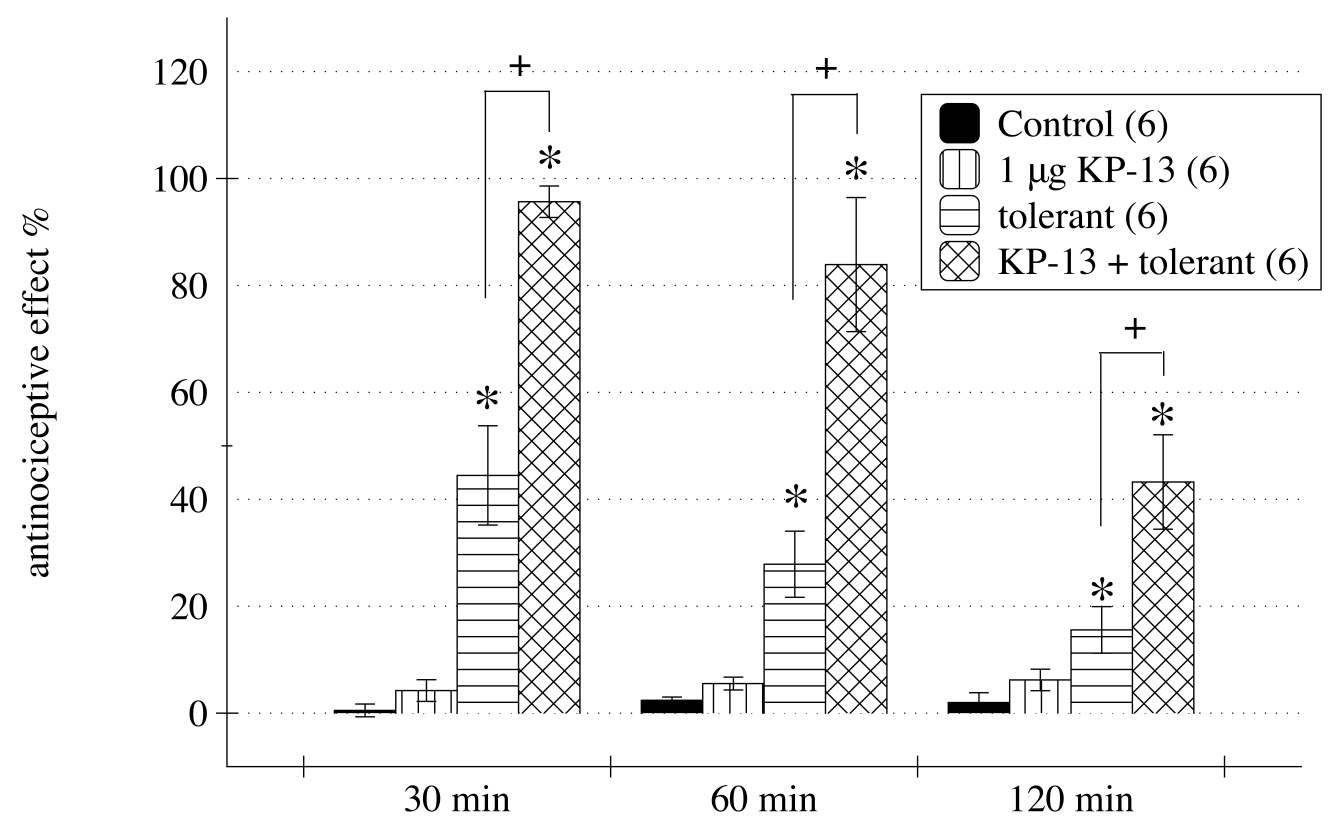

Figure 20: The effect of KP-13 on acute morphine tolerance in the tail-flick test ${ }^{20}$

\subsubsection{Effect of KP-13 on Naloxone-Precipitated Acute Morphine With- drawal}

In the naloxone-precipitated withdrawal studies KP-13 caused a marked decrease in the jumping latency $[\mathrm{F}(3,39)=19.995, \mathrm{p}=0.008$; Figure 21] of animals from the platform.

The two-factor analysis of variance on weight changes revealed a significant main effect for the treatments factor $[\mathrm{F}(3,118)=36.746, \mathrm{p}<0.001]$ and a significant main effect for the time factor $[\mathrm{F}(2,118)=7.445, \mathrm{p}<0.001]$, however the interaction between treatments and time was not significant $[\mathrm{F}(6,118)=0.245, \mathrm{p}=0.96]$, so the

\footnotetext{
${ }^{19}$ Mean and SEM are expressed. Numbers in parenthesis denote the number of animals used. * $\mathrm{p}<0.05$ vs. control. $+\mathrm{p}<0.05$.

${ }^{20}$ Mean and SEM are expressed. Numbers in parenthesis denote the number of animals used. * $\mathrm{p}<0.05$ vs. control. $+\mathrm{p}<0.05$.
} 
effect of different levels of treatments does not depend on what level of time is present. The two-way ANOVA on body temperature changes yielded a significant main effect for the treatments factor $[\mathrm{F}(3,118)=140.576, \mathrm{p}<0.001]$ and a significant main effect for the time factor $[\mathrm{F}(2,118)=45.568, \mathrm{p}<0.001]$, however the interaction between treatments and time was not significant $[\mathrm{F}(6,118)=1.431, \mathrm{p}=0.209]$, the effect of different levels of treatments does not depend on what level of time is present. Morphine tolerant mice showed a significant reduction in both weight (data not shown) and temperature (Figure 22) within the different levels of time (15 min, 30 min and $60 \mathrm{~min}$ ) [p $<0.001]$, however the KP-13-treated morphine tolerant group did not differ significantly from the morphine tolerant group. Only a slight tendency for KP-13 to further reduce the weight loss and hypothermia was observed. Of note is the result that KP-13 alone caused a marked elevation in body temperature compared to the control animals within all levels of time [p $<0.001]$ (Figure 22).

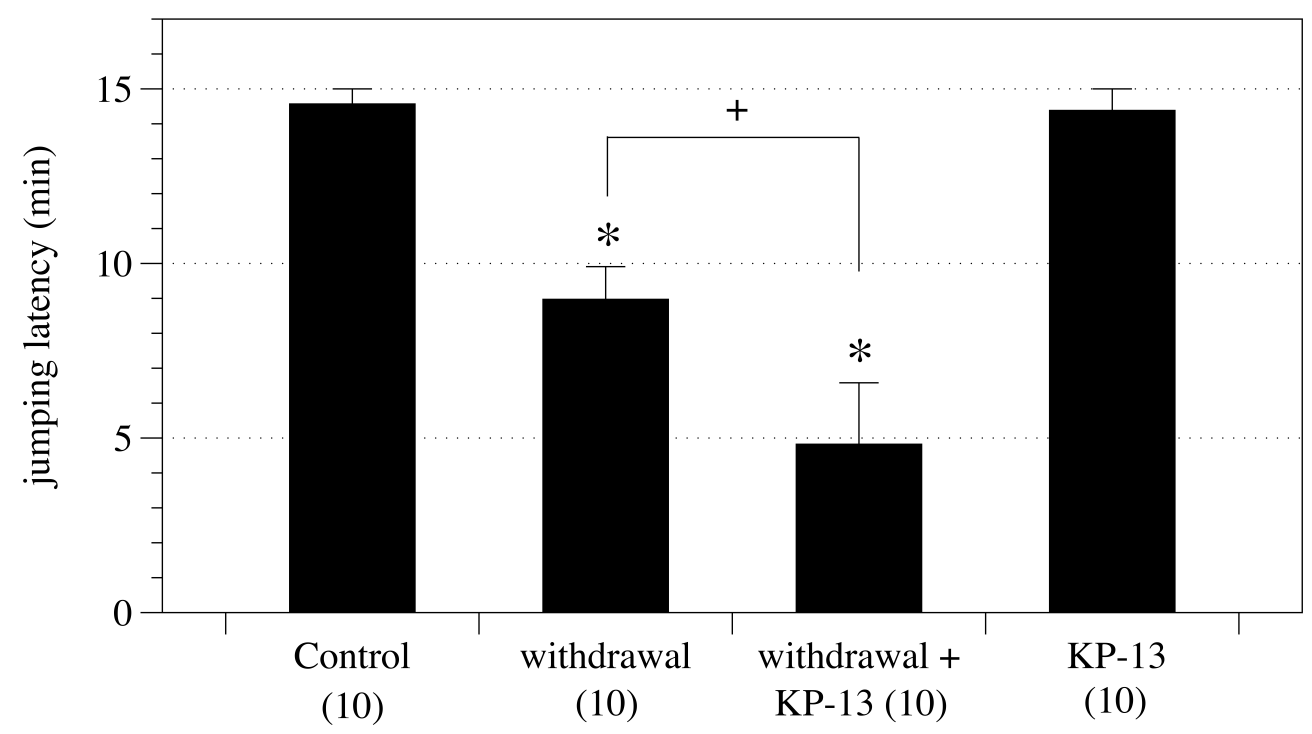

Figure 21: The effect of KP-13 on jumping behaviour in naloxone-precipitated morphine withdrawal. ${ }^{21}$

\footnotetext{
${ }^{21}$ Mean and SEM are expressed. Numbers in parenthesis denote the number of animals used. * $\mathrm{p}<0.05$ vs. control. $+\mathrm{p}<0.05$.
} 


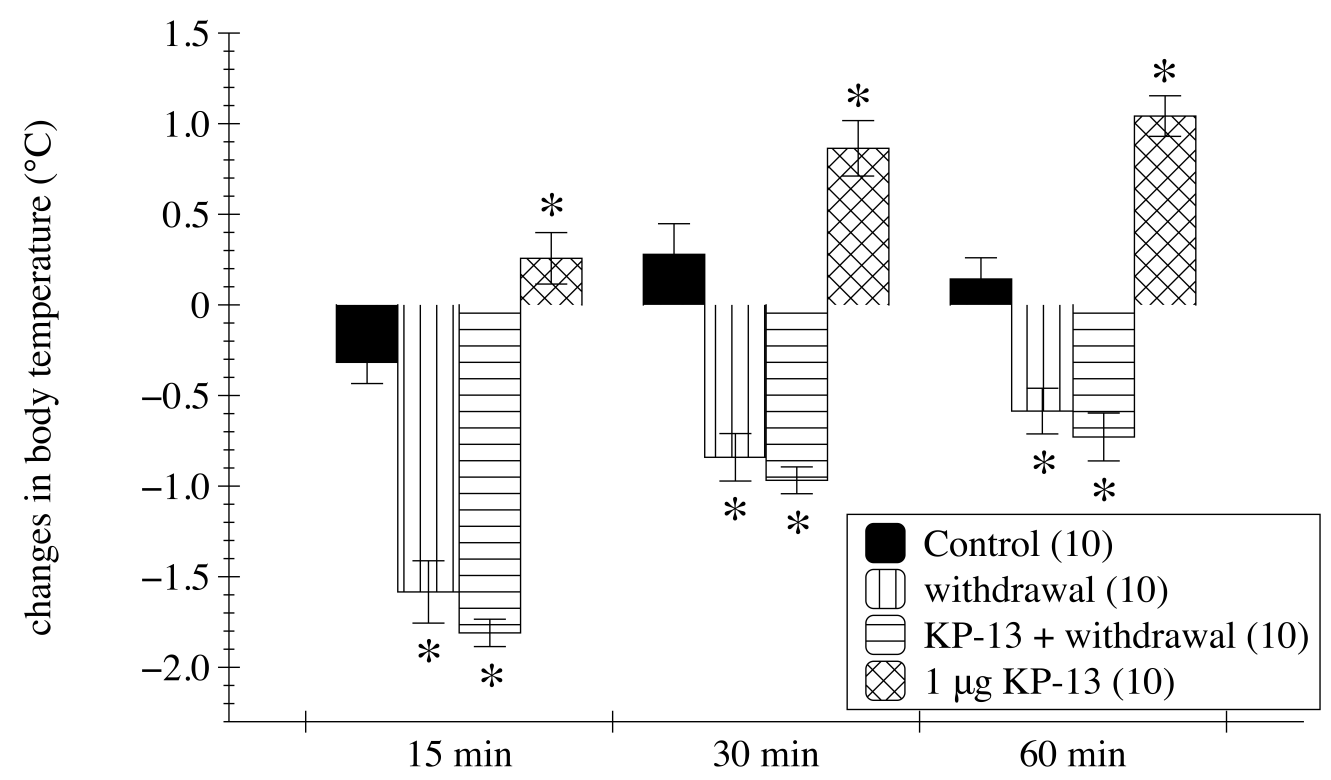

Figure 22: The effect of KP-13 on the hypothermia induced by naloxone-precipitated morphine withdrawal ${ }^{22}$

\subsection{Discussion}

Central administration of KP-13 cause a marked hyperalgesia in the tail-flick test. This is in accordance with previous findings in hot plate and formalin tests conducted by Spampinato et al. [206] and recent results that of Elhabazi et al [50]. In our experiments no linear dose-response curve, but rather an inverted bell-shaped response was observed, which is well known in the literature, and has already been described in case of endomorphins [22] and other neuropeptides [146]. Possible mechanism for this phenomenon could be homologous desensitization by G-protein coupled receptor kinases that phosphorylate already activated receptors thus lowering the responsiveness of the cell specifically to ligands of those receptors [54, 173]. Activation of less-specific inhibitory receptors at higher concentrations [77] or postsynaptic down-regulation of the receptor itself [6] might also explain such a dose - response relationship. The effect of KP-13 on pain sensitivity may be mediated through its cognate receptor, KISS1R, or the NPFF1 and NPFF2 receptors. In support of KISS1R mediation stands several results. First, kisspeptin and KISS1R are expressed in neuronal structures involved in nociception signalling such as dorsal root ganglia and the dorsal horn lamina I and II of the spinal cord as well as brain regions such as hippocampus, amygdala and periaqueductal grey [94, 47, 140]. This pattern of expression suggests a function in pain modulation. Second, in chronic inflammatory pain model kisspeptin and KISS1R up-regulation was detected at the level of the dorsal root ganglia and dorsal

\footnotetext{
${ }^{22}$ Mean and SEM are expressed. Numbers in parenthesis denote the number of animals used. * $\mathrm{p}<0.05$ vs. control.
} 
horn neurones [140]. Third, Spampinato et al. reported that the KISS1R antagonist, kisspeptin-234 exhibits a clearly analgesic effect in formalin test [206]. Fourth, the NPFFR agonist, NPFF in numerous studies caused analgesia when the route of administration was intrathecal instead of icv. [165]. Based on the fact, that kisspeptin showed to lower pain sensitivity in case of intrathecal and intraplantar injections, it is plausible that the effect of kisspeptin is mediated by the KISS1R and not by the NPFFRs. However, in the face of the above mentioned data, Elhabazi et al. in a recent publication reported that RF9, a selective NPFFR antagonist, suppressed the hyperalgesic and anti-morphine activity of icv. administered kisspeptin [50]. In this study the route of administration compared to the study conducted by Spampinato et al. differed as animals received kisspeptin icv. and not peripherally. Additionally, receptor binding data and two different functional assays provide further support, in which all RF-amide peptides were found to target NPFF1R and NPFF2R in a nanomolar concentration range [50]. Furthermore, both NPFF1R and NPFF2R have been previously indicated in the modulation of pain [102]. Hence, these results indicate NPFFR involvement, at least, in the central kisspeptin actions rather then KISS1R mediation. However, it must be noted that a recent publication raises the possibility that RF9 might not be a true selective antagonist of NPFF receptors as it was unable to reverse the anorectic effect of a NPFF analogue and alone displayed an anorectic effect as well [122. Undoubtably, results from these studies have been inconclusive and further investigation must be conducted to clarify the receptors involved in kisspeptin's pain modulatory effect.

The present results revealed an interaction between centrally injected kisspeptin and morphine. KP-13 showed a clear anti-morphine activity as it blunted the analgesic effect of a single injection of morphine. This result is in concert with previous publication in which KP-10 reversed morphine analgesia as well, the effect of which have been blocked by RF9. Thus, this effect may also be mediated by the NPFF system, rather then the KISS1R as NPFF receptors are highly co-localised with opioid receptors [50]. Furthermore, in our experiments KP-13 inhibited the development of acute tolerance to morphine. Short-term tolerance, an exposure to morphine up to 1 day, can be due to multiple adaptive and/or counter adaptive mechanisms. Adaptive mechanisms refer to regulatory processes that directly decrease opioid response or sensitivity: agonist stimulation of $\mu$ opioid receptor (MOR) results in rapid desensitisation and impaired resensitisation together with reduced recycling of MOR receptors to the surface [29, 229]. On the other hand, counter adaptive mechanisms engaging opposing or compensatory regulatory mechanisms might also contribute to the development of tolerance [70]. As an example, multiple neuropeptides have been implicated to have opioid modulating actions in the CNS: orphanin FQ/nociceptin, Tyr-MIF-1, calcitonin gene-related peptide and NPFF [70]. As kisspeptin has been 
previously demonstrated to bind and activate NPFF receptors [121], it is plausible that its effect on acute morphine tolerance is mediated by the NPFF system. Results of several experiments suggest that NPFF might play a role in morphine tolerance and dependence. First, antibodies against the peptide can reverse morphine tolerance [101]. Second, NPFF was found to induce withdrawal-like symptoms [123]. Last, more recent publications have reported that the tolerance inducing effect of NPFF might be mediated by GRK2-dependent phosphorilation of MOR induced by NPFF receptor activation in cell cultures, which will ultimately lead to a decrease in the number of functional MOR with no associated internalisation of the receptors [147]. However, based on the above mentioned data, NPFF receptors induce tolerance rather then inhibit it, which is in contrast with our results with KP-13. This discrepancy might be explained by the difference in treatment protocols used in previous publications with NPFF compared to our experiments. In other studies NPFF was co-administered with morphine, however in our study the animals received KP-13 $60 \mathrm{~min}$ before morphine treatment. It is possible that kisspeptin already reduced the number of functional MORs on the cell surface by the time of morphine treatment, thus blunting the tolerance-inducing effect of morphine [185]. Another possible reason behind our results might be that the tolerance-inhibiting action of KP-13 was mediated not by NPFFRs but the KISS1R. This is further supported by the distribution data of KISS1R expression and the diverse signal transduction cascades mobilised in case of receptor activation [94, 24].

Our results also demonstrate that KP-13 aggravates naloxone-precipitated abstinence syndrome. However, it must be noted that a significant change was only detected in escape behaviour (jumping latency), significant change in temperature and weight between the morphine withdrawal and the KP-13 treated morphine withdrawal groups was not found, only a tendency was observed. As previously mentioned, the NPFF system as an opioid-modulating system involved in homeostasis counteracts the action of opioids contributing possibly to the development of tolerance [70. In withdrawal studies NPFF was able to produce some signs of a withdrawal syndrome in morphine-dependent rats [123]. Furthermore, the immunoneutralisation of NPFF or injection of antisense oligonucleotides to the precursor proNPFFA decreased the intensity of withdrawal signs in morphine-tolerant animals [58, 101, 124]. This suggests that NPFF system might play a role in the mediation of the withdrawal syndrome. Taking these data into consideration it is possible that the effect of KP-13 on withdrawal is mediated by the NPFF system.

Another interesting observation of our experiments was that KP-13 induced a hyperthermia in the animals revealed by the temperature recordings in the acute withdrawal study. $1 \mu \mathrm{g}$ of KP-13 caused a marked elevation of body temperature 15 , 30 and 60 minutes after peptide treatment compared to control mice. This underlies 
our previous results in rats, in which both $1 \mu \mathrm{g}$ and $2 \mu \mathrm{g}$ of KP-13 induced a lasting (appr. $6 \mathrm{~h}$ long) hyperthermia. Thus, it seems that the hyperthermic action of KP-13 is shared among the two species.

In conclusion, our results indicate that centrally injected KP-13 reduces the pain threshold in the tail-flick test, reverses morphine analgesia and reduces acute morphine tolerance. Furthermore, KP-13 seems to worsen the withdrawal signs precipitated by naloxone in adult mice. Our data confirm and provide further support to the concept that all RF-amide peptides might play a modulatory role in pain sensation and raises the idea that with their diverse neuroendocrine functions they might be important for the integration of neuroendocrine and nociceptive processes. In point of fact, several lines of evidence suggest an interaction between the reproductive axis and pain sensitivity, therefore kisspeptin might be an additional factor relaying information about reproductive state to nociceptive centres. 


\section{Conclusion}

The thesis was set out to explore if kisspeptins have a more widespread function in the CNS then the regulation of the HPG axis. We have proposed a role for kisspeptin in the organisation of the stress response and stress-associated behaviours. The study has also sought to know whether kisspeptin, similarly to other RF-amide peptides can modulate pain sensitivity and can impact the acute actions of morphine on nociception. The main findings were presented and evaluated within the respective empirical sections: Section 2: Kisspeptin Modulates HPA Axis Activity, Behaviour and Temperature of Rats; Section 3: Kisspeptin Inhibits Depressive Behavior in Mice; Section 4: Kisspeptin Modulates Pain Sensation in Mice. This section will synthesise these findings and attempt to provide a conceptual framework by which these results could be interpreted.

\subsection{Kisspeptin and the Stress Response}

Our findings are in complete harmony with the growing body of evidence suggesting that kisspeptin may play a more general role in autonomic, neuroendocrine and behavioural regulation. The peptide takes part in cardiovascular [136] and metabolic [17] functions, pregnancy [11] and cognitive processes [3, 215]. Clearly, the control of the aforementioned processes necessitates integration with gonadal activities. The gender-dependent nature of the stress response, stress tolerance and longevity, the interactions between the HPG axis and the HPA system have been well described in the literature [27, 110, 99, 223, 228]. Sexual steroids influence the expression of CRH and AVP in the hypothalamus [186, 222], whereas chronic stress suppresses the reproductive function [27, 110]. However, a series of experiments demonstrate that glucocorticoid release from the adrenal gland, in actuality, preserves the HPG activity during stress [131, 130]. In light of this and the effect of kisspeptin, a prominent stimulator of $\mathrm{GnRH}$ release, on the HPA axis activity, the concept on the interplay between the HPG and HPA axises needs to be revisited in order to truly understand how integration between them is managed. Kisspeptin has also already been implicated in sensing and relaying information about energy stores to the HPG axis [42]. Animal studies revealed reduced expression of Kiss1 mRNA and gonadotrophin secretion in fasting states [25, 119, 86, 126]. Also, leptin may signal metabolic state of the body through kisspeptin neurones. Leptin as a critical adipose hormone is secreted in proportion to fat stores and is known to be essential for pubertal onset and fertility [28]. GnRH neurones do not have leptin receptor, however kisspeptin neurones in the mice ARC do express it [177, 8]. Smith et al. demonstrated that leptin-deficient ob/ob mice had a reduced expression in the Kiss1 mRNA expression, which was partially reversible by leptin treatment [202]. In a 
rat model of diabetes mellitus, similarly, a decreased hypothalamic Kiss1 mRNA expression with low levels of circulating sex steroids were found that was reversed by kisspeptin administration [26]. Furthermore, a number of other metabolic modulators have been linked with kisspeptin neuronal activity directly or indirectly like insulin [176], ghrelin [128] and central hypothalamic regulators [42]. All of these findings point to the possibility that changes in kisspeptin signalling might be responsible for the compromised fertility in altered energy balance. Taking these phenomena and the versatile physiological functions of kisspeptin into account, it is apparent that, besides the well-characterised PrRP [112, 214, 161, further members of the RF-amide family may play integrative roles in the harmonisation of the HPG and HPA activity.

\subsection{Kisspeptin and Nociception}

On another note, sex differences in pain sensitivity and variations in pain threshold and pain tolerance over the menstrual cycle as well as the overrepresentation of characteristic pain syndromes such as fibromyalgia, migraine, tension headache, trigeminal neuralgia, carpal tunnel syndrome and temporomandibular disorders in women point toward the involvement of the reproductive system in pain modulation [219, 52, 163. Of additional interest are the changes occurring with the onset of menopause. It has been shown that after menopause a decrease in endogenous opioid production occurs, which have been associated with the symptomatology of post menopause and hormone replacement therapy restored opioid levels [59, 151]. Clearly, there is a connection between the HPG axis and the regulation of pain sensation, however, the underlying mechanism is not well understood and many of the published studies, both animal and human, experimental and clinical reported, at least, partly contradictory results. Gonadal hormones including estrogens and progesterone have been implicated in affecting pain sensitivity, however again results are contradictory as a clear anti or pronociceptive effect could not be demonstrated for either [143, 209, 63, 227, 34]. Our results taken together with the above mentioned data raises the possibility that kisspeptin might provide a link between the reproductive and pain modulatory systems.

\subsection{Kisspeptin and Circadian Rhythm}

The dense expression of kisspeptin in the ARC and the innervations of the suprachiasmatic nucleus [31] underlines our findings and argues for the role of the peptide in the circadian regulation of metabolic processes, core body temperature, pain sensation and hormone production. In point of fact, the basal HPA activity shows a circadian rhythm that is provided by input from the suprachiasmatic nucleus, leading to the pulsatile secretion of $\mathrm{CRH}$ [144, 224]. The role of kisspeptin in circadian 
control is further supported by recent publications establishing the kisspeptin system as an important relay centre for the integration of environmental cues and the precise timing of puberty [154], the pre-ovulatory LH surge [91, 201], and structural plasticity in seasonal reproduction [108]. Similarly, the observed effect in our experiments on motor paradigms [188] and pain sensation [60] can also be attributed to a plausible regulatory role in circadian activity, sleep-wake cycle, arousal and autonomic regulation suggested by the expression of kisspeptin neurones in the suprachiasmatic nucleus 31 and the pre-optic nucleus of the hypothalamus 32 .

\subsection{Limitations of the Study and Implications for the Future}

Limitations of the studies on which this thesis was based on must be addressed as well. The interpretation of the above presented results need careful consideration. First, the seemingly contradictory results on anxiety and depressive behaviour in rats and mice draw attention to the differences among animal species. Second, this study did not investigate and therefore could not distinguish if the observed effects of kisspeptin are truly that of KISS1R mediation and not of the more general effects of other RF-amide peptides due to NPFF receptor activation. As a consequence, further investigations are necessary to clarify the mediation and signal transduction of the presented physiological phenomena, with special emphasis on the separation of the unique and overlapping features in the activity profile of the different RFamides. Furthermore, the mode of kisspeptin administration, as with most of peptides, provides quite a challenge and thus there is a need for the development of non-peptidergic analogues [49]. With these it might be possible to further elaborate the true spectrum of its physiological actions and may provide a new avenue for the development of novel strategies for reproductive endocrine disorders. In point of fact, there are multiple clinical trials underway to investigate kisspeptin's possible effect and therapeutic value in post menopause, diabetes mellitus, disorders of puberty and infertility. The potential ability of kisspeptin to influence pain sensitivity, response to analgesic treatment and mood cannot be disregarded and must be further investigated in both animals and humans. 


\section{Summary}

The objective of this dissertation was to explore if kisspeptins have a more widespread function in the CNS then the regulation of the reproductive axis. Kisspeptin, a member of the RF-amide family, is an endogenous neurohormone responsible for the organisation of the HPG axis. As the product of the Kiss-1 gene it is present in four biologically active forms consisting of 54,14, 13 and 10 amino acids. Both the distribution data of the peptides and its cognant receptor, both the already wellestablished function of related RF-amide peptides in nociception and neuroendocrine processes, as well as the emerging evidence associating kisspeptins with metabolic integration underlies the need for further studies. Therefore, we have investigated if centrally injected kisspeptin has any role in the organisation of the stress response and stress-associated behaviours, general activity and thermoregulation. We have also sought to know whether kisspeptin, similarly to other RF-amide peptides can modulate pain sensitivity and can impact the acute actions of morphine on nociception.

KP-13 was administered icv. in different doses to adult male Sprague-Dawley rats, the behaviour of which was then observed by means of telemetry, OF and EPM tests. Additionally, plasma concentrations of corticosterone were measured in order to assess the influence of KP-13 on the HPA system. The effects on core temperature were monitored continuously via telemetry. To assess the mediation of KP's effect on EPM behaviour AVP1R or KISS1R antagonists were administered 30 min before peptide treatment, whereas in the corticosterone measurements AVP1R antagonist and $\alpha$-helical $\operatorname{CRF}(9-41)$ pretreatments were applied.

In another set of experiments antidepressant-like effects of KP-13 were studied and the potential involvement of the adrenergic, serotonergic, cholinergic, dopaminergic and gabaergic receptors in its antidepressant-like effects was investigated in a modified FST in mice. The mice were pretreated with a non-selective $\alpha$-adrenergic receptor (AR) antagonist, phenoxybenzamine, an $\alpha_{1} / \alpha_{2} \beta$-AR antagonist, prazosin, an $\alpha_{2}$-AR antagonist, yohimbine, a $\alpha$-AR antagonist, propranolol, a mixed $5-H T_{1} / 5-H T_{2}$ serotonergic receptor antagonist, methysergide, a nonselective $5-H T_{2}$ serotonergic receptor antagonist, cyproheptadine, a nonselective muscarinic acetylcholine receptor antagonist, atropine, a D2, D3, D4 dopamine receptor antagonist, haloperidol, or a $\gamma$-aminobutyric acid subunit A (GABA-A) receptor antagonist, bicuculline.

Finally, in the third study we have endeavoured to shed light on the possible interaction of kisspeptin with morphine on nociception in adult male mice. Following the icv. administration of KP-13, the pain sensitivity was measured by a heat-radiant tail flick test. To assess the effect of KP-13 on acute morphine analgesia, the most effective dose was injected 30 minutes before a single subcutaneous dose of morphine 
$(2.4 \mathrm{mg} / \mathrm{kg})$. Furthermore, acute morphine tolerance was evaluated by giving a bolus injection of morphine $(60 \mathrm{mg} / \mathrm{kg}) 24 \mathrm{~h}$ before the pain sensitivity to a challenge dose of morphine $(4 \mathrm{mg} / \mathrm{kg}$ ) was measured. To evaluate if KP-13 has an effect on withdrawal signs, $3 \mathrm{~h}$ after the development of acute morphine tolerance naloxoneprecipitated withdrawal was inducted and stereotyped jumping behaviour, weight and body temperature changes were observed.

Our results demonstrated that KP-13 stimulated the horizontal locomotion in the OF test and decreased the number of entries into and the time spent in the open arms during the EPM tests, which was blocked by both the AVP1R and KISS1R antagonists. The peptide also caused marked elevations in the spontaneous locomotor activity and the core temperature recorded by the telemetric system, and significantly increased the basal corticosterone level, the last of which was prevented by again the AVP1R blocker.

The FST revealed that KP-13 reversed the immobility, climbing and swimming times, suggesting antidepressant-like effects. Phenoxybenzamine, yohimbine and cyproheptadine prevented the effects of KP-13 on the immobility, climbing and swimming times, whereas prazosin, propranolol, methysergide, atropine, haloperidol and bicuculline did not modify the effects of KP-13.

Furthermore, our results showed that KP-13 significantly decreased the pain threshold. Peptide treatment also depressed the acute nociceptive effect of morphine and attenuated the development of morphine tolerance. In the withdrawal experiment KP-13 was found to exacerbate withdrawal signs, however our results were not significant.

In conclusion, our data indicate that icv. administered KP-13 stimulates the HPA axis through the release of AVP, induces hyperthermia, activates motor behaviour and causes anxiety in rats by the activation of KISS1R and by AVP secretion. Our results also demonstrate that the antidepressant-like effects of KP-13 in a modified mouse FST are mediated, at least in part, by an interaction of the $\alpha_{2}$-adrenergic and $5-H T_{2}$ serotonergic receptors. Finally, our data underlies kisspeptin's hyperalgesic effect and suggest that central KP-13 administration can modify the acute effects of morphine. 


\section{7 Összefoglalás}

A kisspeptin egy Arg-Phe (RF)-amid családba tartozó neurohormon, melynek elsődleges szerepe a gonadális tengely központi szabályozásában van. Az RF-amidok egy viszonylag újonnan megismert peptid család tagjai, melyek elsősorban a nocicepció és neuroendokrin folyamatok szabályozásában vesznek részt. A kisspeptin rendszer szerepe már igazolt bizonyos humán kórképekben (hypogonadotrop hypogonadizmus, pubertas praecox), melyek kapcsán felmerült lehetséges terápiás célpontként is, így fontos lehet minden szervezetben betöltött funkciójának a megismerése.

A kisspeptin a Kiss-1 gén terméke, négy biológiailag aktív formában létezik: 54, 14, 13 és 10 aminosav szekvenciával. A peptid és receptora számos helyen kimutatható a központi idegrendszerben, többek között a limbikus rendszerben, striátumban, hipofízisben és a hipotalamusz paraventrikuláris magjában, mely a stressz tengely központja. A kisspeptin nemcsak a kisspeptin receptorhoz (KISS1R), hanem a neuropeptid FF2 receptorhoz is kötődik, melynek neuroendokrin folyamatok szabályozásában betöltött szerepe már igazolt. Az RF-amid peptideknek különbözik a hatásspektrumuk. A PrRP, például aktiválja a hipotalamusz-hipofízis-mellékvesekéreg (HHM) tengelyt, fokozza a sztereotíp viselkedést, valamint presszor hatást vált ki. Ugyanakkor, a neuropeptid AF csökkentette a szívfrekvenciát, míg a stressz tengelyre, ill. lokomócióra stimuláló hatást fejtett ki. Fontos még kiemelni, hogy számos tagjuk részt vesz a fájdalomérzet modulálásában, azonban hatásuk, úgy túnik a receptor szelektivitásuktól, valamint az anyagbeadás helyétől (centrális, ill. perifériás) is függ. Továbbá, korábban kimutatták a kisspeptin receptor jelenlétét a gerincvelő hátsó szarvában, ill. fájdalom küszöböt csökkentő hatását. Figyelembe véve ezen eredményeket, kísérleteink során a kisspeptin hatását vizsgáltuk a HHM tengely múködésére és a stressz kiváltotta viselkedésre, a termoregulációra, valamint a fájdalomérzet szabályozására.

Kísérleteinket hím Sprague-Dawley patkányokon és hím egereken in vivo és in vitro rendszerek segítségével végeztük. Patkány kísérleteinkben a peptidet intracerebroventrikularisan (icv.) adagoltuk, majd 30 perccel késóbb törzsvért nyertünk a plazma kortikoszteron meghatározásához vagy megfigyeltük az állatok viselkedését a nyílt tér, ill. a megemelt keresztpalló tesztben a szorongás-szerú tünetek felméréséhez. Telemetria rendszer segítségével vizsgáltuk a kisspeptin hatását a spontán mozgásaktivitásra és a maghômérsékletre. Hogy tisztázzuk milyen mediátorok felelősek a kisspeptin kortikoszteron szintre és szorongásra gyakorolt hatásának mediálásában, elókezelést alkalmaztunk receptor antagonistákkal: nem szelektív CRF receptor antagonistával ( $\alpha$-helikális $\operatorname{CRF}(9-41)$ ), szelektív vasopressin 1 receptor (AVP1R) blokkolóval, valamint KISS1R blokkolóval.

Továbbá, hogy felmérjük a kisspeptin hatását depressziós magatartásra, icv. kis- 
speptin beadást követôen erôltetett úszás tesztet végeztünk CD1 egereken. Nemszelektív $\alpha$-adrenerg receptor (AR) (phenoxybenzamin), $\alpha_{1} / \alpha_{2} \beta$-AR (prazosin), $\alpha_{2^{-}}$ $\mathrm{AR}$ (yohimbin), $\alpha$-AR (propranolol), kevert $5-H T_{1} / 5-H T_{2}$ szerotoninerg receptor (methysergid), nem-szelektív $5-H T_{2}$ szerotoninerg receptor (cyproheptadin), nemszelektív muszkarin típusú acetilkolin receptor (atropin), D2, D3, D4 dopamin receptor (haloperidol), és végül $\gamma$-aminovajsav A alegység (GABA-A) receptor (bicucullin) antagonistákkal szeretnénk feltérképezni milyen mediátorok közvetítésével váltja ki hatását.

Végül, a kisspeptin nocicepcióra kifejtett hatását termonociceptív farokvisszahuzásos teszt segítségével vizsgáltuk CFLP egerekben. A peptid icv. beadását követóen mértük a farokvisszahúzás latenciát 30, 60 és 120 perc után. Ezenkívül, mértük a kisspeptin hatását akut morfin kiváltotta antinocicepcióra, valamint az akut tolerancia kialakulására. Ez utóbbi kapcsán kisspeptin kezelés után 60 perccel az állatok egy toleranciát indukáló dózisú morfint kaptak szubkután (sc.), majd 24 óra múlva teszt-dózisú morfin után mértük az antinociceptív hatást. Az akut morfin megvonás tüneteire gyakorolt hatását az egerekre jellemzô sztereotíp ugrási latencia meghatározásával, valamint a testhőmérséklet és testsúly folyamatos regisztrálásával igyekeztünk felmérni.

Eredményeink azt mutatták, hogy a kisspeptin stimulálta a kortikoszteron szekréciót és az explorátoros lokomóciót a nyílt tér tesztben, valamint szignifikánsan csökkentette a patkányok nyitott karban eltöltött idejét a megemelt keresztpalló tesztben. Telemetriás eredményeink szerint a kisspeptin fokozta a spontán mozgásaktivitást és a maghőmérsékletet. Az antagonista elókezelések közül az $\alpha$-helikális CRF(9-41) nem hatott szignifikánsan a kisspeptin által kiváltott HHM tengely aktivációra, valamint szorongásra; ellenben a AVP1R blokkoló mindkét kísérletben kivédte azt. A KISS1R blokkoló szintén csökkentette a kisspeptin kiváltotta szorongást. Ugyanakkor, CD1 egereken végzett kísérleteink eredményeképpen a kisspeptin antidepresszív hatása igazolódott, melyet a phenoxybenzamin, a yohimbin, valamint a cyproheptadin elókezelés kivédett. Farokvisszahúzásos kísérletekben a kisspeptin csökkentette a fájdalomküszöböt és az akut morfin kiváltotta analgéziát. Továbbá, kisspeptin kezelésre csökkent a morfin akut toleranciát kiváltó hatása, ill. a megvonásban tapasztalt ugrási latencia.

Eredményeink alapján elmondhatjuk, hogy a kisspeptin szerepet játszhat a stressz válasz szabályozásában és szorongást vált ki patkányban, míg egérben antidepresszív hatásúnak bizonyult. Antagonista kezeléseink igazolták, hogy az elóbbi feltehetốn KISS1R aktiváció és AVP centrális felszabadulásán keresztül jön létre, míg az utóbbi $\alpha_{2}$-AR és $5-H T_{2}$ receptorok interakciója révén következhet be. Ugyanakkor mind patkányban, mind egérben a kisspeptin emelte a testhőmérsékletet. Emellett, hiperalgéziát okoz és befolyással bír a morfin kiváltotta akut analgéziára, toleranciára 
és megvonásra. Végül, ezen disszertáció alapját képezô kutatás rámutat arra, hogy nemcsak a többi RF-amid peptid rendelkezik szélesebb hatásspektrummal, hanem a kisspeptin is. Ennek hátterében állhat cirkadián ritmus szabályozásban feltételezett szerepe, melyre többek között utal kifejeződése a cirkadián ritmus generálásáért felelôs agyi struktúrákban, valamint a már ismert szerepe a menstruációs ciklus és pubertás kialakulásában. 


\section{Acknowledgments}

First and foremost, I would like to thank my advisors, Professor Gyula Telegdy, who has been a steadfast and true definition of a mentor throughout my Ph.D and Dr. Miklós Jászberényi, who introduced me to the world of scientific research and sparked my fascination with neuroscience and neuroendocrinology. They encouraged and taught me to ask questions, think critically, make mistakes, and enjoy science.

I would like to thank Professor Gyula Szabó, the Chairman of the Department of Pathophysiology,s who created the kind of tight-knit community that any scientist would be lucky to have and supported my research whole-heartedly throughout the years.

I am also grateful to Dr. Zsófia Mezei, Dr. Zsolt Bagosi and Dr. Júlia Szakács for welcoming me wholeheartedly into the Department of Pathophysiology, for being so generous with their time and energy, and for the hours of thoughtful conversations about science, experiments, and life. I have also had a tremendous time working with other members of the Department, Nándor Lipták, Dr. Anikó Babits and Dr. Árpád Gecse and with our "scientific circle" students, Bálint Kincses and Katica Bene, who together created an environment of critical thinking, intellectual stimulation, and unwavering support.

I would like to especially thank Csilla Aradán and Szilvia Sárkány, Gusztáv Kiss, Ildikó Sipos and Ágnes Pál for their invaluable help with the laboratory experiments and for making this department feel like home; they were there with me at each step along the way.

I would like to express my gratitude to Dr. Tanaka Masaru for providing invaluable advice during the years and special thanks for our collaborative work and allowing me to include it in my $\mathrm{PhD}$ dissertation.

I would additionally like to thank my parents, Mária and Csaba for their support, encouragement and patience with me throughout graduate school and for the continuously applied gentle nudge to complete my doctorate.

Thank you to my brother, Tamás, for growing up with me and providing stimulating conversations in the middle of the night, while the majority of this work was done. The force shall be with us, always!

If it was not for them this thesis could not have been written. 


\section{References}

[1] Abbara, A., Ratnasabapathy, R., Jayasena, C., and Dhillo, W. The effects of kisspeptin on gonadotropin release in non-human mammals. Adv Exp Med Biol 784 (2013), $63-87$.

[2] Antoni, F. Vasopressinergic control of pituitary adrenocorticotropin secretion comes of age. Front Neuroendocrinol 14, 2 (1993), 76-122.

[3] Arai, A., AND OrWig, N. Factors that regulate kiss1 gene expression in the hippocampus. Brain Res 1243 (2008), 10-18.

[4] Armario, A. Activation of the hypothalamic-pituitary-adrenal axis by addictive drugs: different pathways, common outcome. Trends Pharmacol Sci 31, 7 (2010), 318-325.

[5] Armario, A., Valles, A., Dal-Zotto, S., Marquez, C., and Belda, X. A single exposure to severe stressors causes long-term desensitisation of the physiological response to the homotypic stressor. Stress 7, 3 (2004), 157-172.

[6] Azzi, M., Nicot, A., Gully, D., Kitabgi, P., Berod, A., and Rostene, W. Increase in neurotensin receptor expression in rat brain induced by chronic treatment with the nonpeptide neurotensin receptor antagonist sr 48692. Neurosci Lett 172, 1-2 (1994), 97-100.

[7] Babb, J., Masini, C., Day, H., and Campeau, S. Habituation of hypothalamic-pituitaryadrenocortical axis hormones to repeated homotypic stress and subsequent heterotypic stressor exposure in male and female rats. Stress 17, 3 (2014), 224-234.

[8] Backholer, K., Smith, J., And Clarke, I. Melanocortins may stimulate reproduction by activating orexin neurons in the dorsomedial hypothalamus and kisspeptin neurons in the preoptic area of the ewe. Endocrinology 150, 12 (2009), 5488-5497.

[9] Baldessarini, R., Singh, N., And Jaggi, A. Drug therapy of depression and anxiety disorders. In Goodman and Gilman's The Pharmacological Basis of Therapeutics, L. Brunton, J. Lazo, and K. Parker, Eds. McGraw-Hill Inc., New York, 2006, pp. 429-460.

[10] Bali, A., Singh, N., And JagGi, A. Neuropeptides as therapeutic targets to combat stressassociated behavioral and neuroendocrinological effects. CNS Neurol Disord Drug Targets 13, 2 (2014), 347-368.

[11] Bilban, M., Ghaffari-Tabrizi, N., Hintermann, E., Bauer, S., Molzer, S., Zoratti, C., Malli, R., Sharabi, A., Hiden, U., Graier, W., Knofler, M., Andreae, F., Wagner, O., Quaranta, V., and Desoye, G. Kisspeptin-10, a kiss-1/metastinderived decapeptide, is a physiological invasion inhibitor of primary human trophoblasts. $J$ Cell Sci 117, Pt 8 (2004), 1319-1328.

[12] Binder, E. The role of fkbp5, a co-chaperone of the glucocorticoid receptor in the pathogenesis and therapy of affective and anxiety disorders. Psychoneuroendocrinology 34 Suppl 1 (2009), S186-S195.

[13] Binder, E., Bradley, R., Liu, W., Epstein, M., Deveau, T., Mercer, K., Tang, Y., Gillespie, C., Heim, C., Nemeroff, C., Schwartz, A., Cubells, J., and Ressler, K. Association of fkbp5 polymorphisms and childhood abuse with risk of posttraumatic stress disorder symptoms in adults. JAMA 299, 11 (2008), 1291-1305. 
[14] Binder, E., Salyakina, D., Lichtner, P., Wochnik, G., Ising, M., Putz, B., Papiol, S., Seaman, S., Lucae, S., Kohli, M., Nickel, T., Kunzel, H., Fuchs, B., Majer, M., Pfennig, A., Kern, N., Brunner, J., Modell, S., Baghai, T., Deiml, T., Zill, P., Bondy, B., Rupprecht, R., Messer, T., Kohnlein, O., Dabitz, H., Bruckl, T., Muller, N., Pfister, H., Lieb, R., Mueller, J., Lohmussaar, E., Strom, T., Bettecken, T., Meitinger, T., Uhr, M., Rein, T., Holsboer, F., and MullerMyHsok, B. Polymorphisms in fkbp5 are associated with increased recurrence of depressive episodes and rapid response to antidepressant treatment. Nat Genet 36, 12 (2004), 1319-1325.

[15] Bloch, M., Aharonov, I., Ben Avi, I., Schreiber, S., Amit, A., Weizman, A., And Azem, F. Gonadal steroids and affective symptoms during in vitro fertilization: implication for reproductive mood disorders. Psychoneuroendocrinology 36, 6 (2011), 790-796.

[16] Bonini, J., Jones, K., Adham, N., Forray, C., Artymyshyn, R., Durkin, M., Smith, K., Tamm, J., Boteju, L., Lakhlani, P., Raddatz, R., Yao, W., Ogozalek, K., Boyle, N., Kouranova, E., Quan, Y., Vaysse, P., Wetzel, J., Branchek, T., GerALD, C., AND Borowsky, B. Identification and characterization of two g protein-coupled receptors for neuropeptide ff. J Biol Chem 275, 50 (2000), 39324-39331.

[17] Bowe, J., King, A., Kinsey-Jones, J., Foot, V., Li, X., O’Byrne, K., Persaud, S., AND Jones, P. Kisspeptin stimulation of insulin secretion: mechanisms of action in mouse islets and rats. Diabetologia 52, 5 (2009), 855-862.

[18] Bowers, M., Choi, D., And Ressler, K. Neuropeptide regulation of fear and anxiety: Implications of cholecystokinin, endogenous opioids, and neuropeptide y. Physiol Behav 107, 5 (2012), 699-710.

[19] Bradley, R., Binder, E., Epstein, M., Tang, Y., Nair, H., Liu, W., Gillespie, C., Berg, T., Evces, M., Newport, D., Stowe, Z., Heim, C., Nemeroff, C., Schwartz, A., Cubells, J., And Ressler, K. Influence of child abuse on adult depression: moderation by the corticotropin-releasing hormone receptor gene. Arch Gen Psychiatry 65, 2 (2008), 190200 .

[20] Brailoiu, G., Dun, S., Ohsawa, M., Yin, D., Yang, J., Chang, J., Brailoiu, E., and

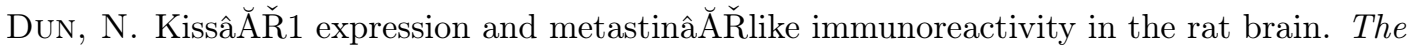
Journal of Comparative Neurology 481, 3 (2005), 314-329.

[21] Buckingham, J. Glucocorticoids: exemplars of multi-tasking. Br J Pharmacol 147 Suppl 1 (2006), S258-S268.

[22] Bujdoso, E., Jaszberenyi, M., Tomboly, C., Toth, G., and Telegdy, G. Effects of endomorphin-1 on open-field behavior and on the hypothalamic-pituitary-adrenal system. Endocrine 14, 2 (2001), 221-224.

[23] CARr, G., And Lucki, I. The role of serotonin receptor subtypes in treating depression: a review of animal studies. Psychopharmacology (Berl) 213, 2-3 (2011), 265-287.

[24] Castano, J., Martinez-Fuentes, A., Gutierrez-Pascual, E., Vaudry, H., TenaSempere, M., And Malagon, M. Intracellular signaling pathways activated by kisspeptins through gpr54: do multiple signals underlie function diversity? Peptides 30, 1 (2009), 10-15.

[25] Castellano, J., Navarro, V., Fernandez-Fernandez, R., Nogueiras, R., Tovar, S., Roa, J., Vazquez, M., Vigo, E., Casanueva, F., Aguilar, E., Pinilla, L., 
Dieguez, C., And Tena-Sempere, M. Changes in hypothalamic kiss-1 system and restoration of pubertal activation of the reproductive axis by kisspeptin in undernutrition. Endocrinology 146, 9 (2005), 3917-3925.

[26] Castellano, J., Navarro, V., Fernandez-Fernandez, R., Roa, J., Vigo, E., Pineda, R., Dieguez, C., Aguilar, E., Pinilla, L., and Tena-Sempere, M. Expression of hypothalamic kiss-1 system and rescue of defective gonadotropic responses by kisspeptin in streptozotocin-induced diabetic male rats. Diabetes 55, 9 (2006), 2602-2610.

[27] Chandran, U., Attardi, B., Friedman, R., Dong, K., Roberts, J., and DeFranco, D. Glucocorticoid receptor-mediated repression of gonadotropin-releasing hormone promoter activity in gt1 hypothalamic cell lines. Endocrinology 134, 3 (1994), 1467.

[28] Chenab, F. Leptin as a regulator of adipose mass and reproduction. Trends Pharmacol Sci 21, 8 (2000), 309-314.

[29] Christie, M. Cellular neuroadaptations to chronic opioids: tolerance, withdrawal and addiction. Br J Pharmacol 154, 2 (2008), 384-396.

[30] Clarke, H., Flint, J., Attwood, A., And Munafo, M. Association of the 5- httlpr genotype and unipolar depression: a meta-analysis. Psychol Med 40, 11 (2010), 1767-1778.

[31] Clarkson, J., D’Anglemont de Tassigny, X., Colledge, W., Caraty, A., and Herbison, A. Distribution of kisspeptin neurones in the adult female mouse brain. J Neuroendocrinol 21, 8 (2009), 673-682.

[32] Clarkson, J., and Herbison, A. Postnatal development of kisspeptin neurons in mouse hypothalamus; sexual dimorphism and projections to gonadotropin-releasing hormone neurons. Endocrinology 147, 12 (2006), 5817-5825.

[33] Cottingham, C., And WAng, Q. alpha2 adrenergic receptor dysregulation in depressive disorders: implications for the neurobiology of depression and antidepressant therapy. Neurosci Biobehav Rev 36, 10 (2012), 2214-2225.

[34] Coulombe, M., Spooner, M., Gaumond, I., Carrier, J., and Marchand, S. Estrogen receptors beta and alpha have specific pro- and anti-nociceptive actions. Neuroscience 184 (2011), 172-182.

[35] CRYan, J., AND LuCKI, I. Antidepressant-like behavioral effects mediated by 5hydroxytryptamine(2c) receptors. J Pharmacol Exp Ther 295, 3 (2000), 1120-1126.

[36] D'Amour, F., And Smith, D. A method for determining loss of pain sensation. J Pharmacol Exp Ther 72 (1941), 74-79.

[37] D’Anglemont de Tassigny, X., Fagg, L., Carlton, M., and Colledge, W. Kisspeptin can stimulate gonadotropin-releasing hormone (gnrh) release by a direct action at gnrh nerve terminals. Endocrinology 149, 8 (2008), 3926-3932.

[38] Darwin, C. The expression of the Emotions in Man and Animals. Murray, J, London, 1872.

[39] Davis, M., Walker, D., Miles, L., and Grillon, C. Phasic vs sustained fear in rats and humans: role of the extended amygdala in fear vs anxiety. Neuropsychopharmacology 35, 1 (2010), 105-135.

[40] de Bodinat, C., Guardiola-Lemaitre, B., Mocaer, E., Renard, P., Munoz, C., and Millan, M. Agomelatine, the first melatonergic antidepressant: discovery, characterization and development. Nat Rev Drug Discov 9, 8 (2010), 628-642. 
[41] de Boer, H., van Gastel, P., And van Sorge, A. Luteinizing hormone-releasing hormone and postmenopausal flushing. N Engl J Med 361, 12 (2009), 1218-1219.

[42] De Bond, J., And Smith, J. Kisspeptin and energy balance in reproduction. Reproduction 147, 3 (2014), R53-R63.

[43] DE KLOET, E. Functional profile of the binary brain corticosteroid receptor system: mediating, multitasking, coordinating, integrating. Eur J Pharmacol 719, 1-3 (2013), 53-62.

[44] de Roux, N., Genin, E., Carel, J., Matsuda, F., Chaussain, J., And Milgrom, E. Hypogonadotropic hypogonadism due to loss of function of the kiss1-derived peptide receptor gpr54. Proc Natl Acad Sci US A 100, 19 (2003), 10972-10976.

[45] Dekeyne, A., Mannoury la Cour, C., Gobert, A., Brocco, M., Lejeune, F., Serres, F., Sharp, T., Daszuta, A., Soumier, A., Papp, M., Rivet, J., Flik, G., Cremers, T., Muller, O., Lavielle, G., And Millan, M. S32006, a novel 5-ht2c receptor antagonist displaying broad-based antidepressant and anxiolytic properties in rodent models. Psychopharmacology (Berl) 199, 4 (2008), 549-568.

[46] Drolet, G., Dumont, E., Gosselin, I., Kinkead, R., Laforest, S., and Trottier, J. Role of endogenous opioid system in the regulation of the stress response. Prog Neuropsychopharmacol Biol Psychiatry 25, 4 (2001), 729-741.

[47] Dun, S., Bralloiu, G., Parsons, A., Yang, J., Zeng, Q., Chen, X., Chang, J., AND Dun, N. Metastin-like immunoreactivity in the rat medulla oblongata and spinal cord. Neurosci Lett 335, 3 (2003), 197-201.

[48] Dunn, A., Berridge, C., Lai, Y., and Yachabach, T. Crf-induced excessive grooming behavior in rats and mice. Peptides 8, 5 (1987), 841-844.

[49] Egleton, R., And Davis, T. Development of neuropeptide drugs that cross the blood-brain barrier. NeuroRx 2, 1 (2005), 44-53.

[50] Elhabazi, K., Humbert, J., Bertin, I., Schmitt, M., Bihel, F., Bourguignon, J., Bucher, B., Becker, J., Sorg, T., Meziane, H., Petit-Demouliere, B., Ilien, B., And Simonin, F. Endogenous mammalian rf-amide peptides, including prrp, kisspeptin and 26rfa, modulate nociception and morphine analgesia via npff receptors. Neuropharmacology $75 C$ (2013), 164-171.

[51] Figueiredo, H., Bodie, B., Tauchi, M., Dolgas, C., And Herman, J. Stress integration after acute and chronic predator stress: differential activation of central stress circuitry and sensitization of the hypothalamo-pituitary-adrenocortical axis. Endocrinology 144, 12 (2003), $5249-5258$.

[52] Fillingim, R., King, C., Ribeiro-Dasilva, M., Rahim-Williams, B., and Riley, J. R. Sex, gender, and pain: a review of recent clinical and experimental findings. J Pain 10, 5 (2009), 447-485.

[53] Fox, J., AND LowRY, C. Corticotropin-releasing factor-related peptides, serotonergic systems, and emotional behavior. Front Neurosci 7 (2013), 169.

[54] Freedman, N., And Lefkowitz, R. Desensitization of g protein-coupled receptors. Recent Prog Horm Res 51 (1996), 319-51; discussion 352.

[55] Friedman, R. A dry pipeline for psychiatric drugs. The New York Times (2013). 
[56] Fukusumi, S., Fujis, R., And Hinuma, S. Recent advances in mammalian rfamide peptides: the discovery and functional analyses of prrp, rfrps and qrfp. Peptides 27, 5 (2006), 1073-1086.

[57] Funes, S., Hedrick, J. A., Vassileva, G., Markowitz, L., Abbondanzo, S., GoLovko, A., Yang, S., Monsma, F. J., And Gustafson, E. L. The kiss-1 receptor gpr54 is essential for the development of the murine reproductive system. Biochemical and Biophysical Research Communications 312, 4 (2003), 1357-1363.

[58] Gelot, A., Frances, B., Roussin, A., Latapie, J., and Zajac, J. Anti-opioid efficacy of neuropeptide ff in morphine-tolerant mice. Brain Res 808, 2 (1998), 166-173.

[59] Genazzani, A., Petraglia, F., Facchinetti, F., Grasso, A., Alessandrini, G., AND VOLPE, A. Steroid replacement treatment increases beta-endorphin and beta-lipotropin plasma levels in postmenopausal women. Gynecol Obstet Invest 26, 2 (1988), 153-159.

[60] Gilron, I., Bailey, J., And Vandenkerkhof, E. Chronobiological characteristics of neuropathic pain: clinical predictors of diurnal pain rhythmicity. Clin J Pain 29, 9 (2013), 755-759.

[61] Goto, Y., Otani, S., And Grace, A. The yin and yang of dopamine release: a new perspective. Neuropharmacology 53, 5 (2007), 583-587.

[62] Gottsch, M., Cunningham, M., Smith, J., Popa, S., Acohido, B., Crowley, W., Seminara, S., Clifton, D., And Steiner, R. A role for kisspeptins in the regulation of gonadotropin secretion in the mouse. Endocrinology 145, 9 (2004), 4073-4077.

[63] Greenspan, J., Craft, R., LeResche, L., Arendt-Nielsen, L., Berkley, K., Fillingim, R., Gold, M., Holdcroft, A., Lautenbacher, S., Mayer, E., Mogil, J., Murphy, A., And Traub, R. Studying sex and gender differences in pain and analgesia: a consensus report. Pain 132 Suppl 1 (2007), S26-S45.

[64] Griebel, G., And Holmes, A. 50 years of hurdles and hope in anxiolytic drug discovery. Nat Rev Drug Discov 12, 9 (2013), 667-687.

[65] Griebel, G., And Holsboer, F. Neuropeptide receptor ligands as drugs for psychiatric diseases: the end of the beginning? Nat Rev Drug Discov 11, 6 (2012), 462-478.

[66] Grumbach, M. The neuroendocrinology of human puberty revisited. Horm Res 57 Suppl 2 (2002), 2-14.

[67] Han, S., Gottsch, M., Lee, K., Popa, S., Smith, J., Jakawich, S., Clifton, D., Steiner, R., And Herbison, A. Activation of gonadotropin-releasing hormone neurons by kisspeptin as a neuroendocrine switch for the onset of puberty. J Neurosci 25, 49 (2005), 11349-11356.

[68] Hannon, J., And Hoyer, D. Molecular biology of 5-ht receptors. Behav Brain Res 195, 1 (2008), 198-213.

[69] Harbuz, M., And Jessop, D. Stress and inflammatory disease: widening roles for serotonin and substance p. Stress 4, 1 (2001), 57-70.

[70] Harrison, L., Kastin, A., And Zadina, J. Opiate tolerance and dependence: receptors, g-proteins, and antiopiates. Peptides 19, 9 (1998), 1603-1630.

[71] Heinrichs, S., And Koob, G. Corticotropin-releasing factor in brain: a role in activation, arousal, and affect regulation. J Pharmacol Exp Ther 311, 2 (2004), 427-440. 
[72] Herbison, A., de, T. X., Doran, J., and Colledge, W. Distribution and postnatal development of gpr54 gene expression in mouse brain and gonadotropin-releasing hormone neurons. Endocrinology 151, 1 (2010), 312-321.

[73] Herman, J., Figueiredo, H., Mueller, N., Ulrich-lai, Y., Ostrander, M., Choi, D., And Cullinan, W. Central mechanisms of stress integration: hierarchical circuitry controlling hypothalamo-pituitary-adrenocortical responsiveness. Front Neuroendocrinol 24, 3 (2003), 151-180.

[74] Herman, J., Prewitt, C., and Cullinan, W. Neuronal circuit regulation of the hypothalamo-pituitary-adrenocortical stress axis. Crit Rev Neurobiol 10, 3-4 (1996), 371394.

[75] Hindmarch, I. Expanding the horizons of depression: beyond the monoamine hypothesis. Hum Psychopharmacol 16, 3 (2001), 203-218.

[76] Horiuchi, J., Saigusa, T., Sugiyama, N., Kanba, S., Nishida, Y., Sato, Y., Hinuma, S., AND ARITA, J. Effects of prolactin-releasing peptide microinjection into the ventrolateral medulla on arterial pressure and sympathetic activity in rats. Brain Res 958, 1 (2002), 201209 .

[77] Hu, W., Zhang, C., Yang, H., Zheng, Y., Liu, N., Sun, X., Jen, J., And Jen, M. Mechanism of the dynorphin-induced dualistic effect on free intracellular ca2 + concentration in cultured rat spinal neurons. Eur J Pharmacol 342, 2-3 (1998), 325-332.

[78] Irwig, M., Fraley, G., Smith, J., Acohido, B., Popa, S., Cunningham, M., GottSch, M., Clifton, D., And Steiner, R. Kisspeptin activation of gonadotropin releasing hormone neurons and regulation of kiss-1 mrna in the male rat. Neuroendocrinology 80, 4 (2004), 264-272.

[79] Jaszberenyi, M., Bagosi, Z., Thurzo, B., Foldesi, I., Szabo, G., And Telegdy, G. Endocrine, behavioral and autonomic effects of neuropeptide af. Horm Behav 56, 1 (2009), $24-34$.

[80] Jaszberenyi, M., Bujdoso, E., Bagosi, Z., And Telegdy, G. Mediation of the behavioral, endocrine and thermoregulatory actions of ghrelin. Horm Behav 50, 2 (2006), 266-273.

[81] Jayasena, C., Comninos, A., Nijher, G., Abbara, A., De Silva, A., Veldhuis, J., Ratnasabapathy, R., Izzi-Engbeaya, C., Lim, A., Patel, D., Ghatei, M., Bloom, S., AND Dhillo, W. Twice-daily subcutaneous injection of kisspeptin-54 does not abolish menstrual cyclicity in healthy female volunteers. J Clin Endocrinol Metab 98, 11 (2013), 4464-4474.

[82] Jhamandas, J., And Goncharuk, V. Role of neuropeptide ff in central cardiovascular and neuroendocrine regulation. Front Endocrinol (Lausanne) 4 (2013), 8.

[83] Joels, M., And Baram, T. The neuro-symphony of stress. Nat Rev Neurosci 10, 6 (2009), 459-466.

[84] Joels, M., Karst, H., Krugers, H., and Lucassen, P. Chronic stress: implications for neuronal morphology, function and neurogenesis. Front Neuroendocrinol 28, 2-3 (2007), $72-96$.

[85] Jones, D., Kortekaas, R., Slade, P., Middlemiss, D., And Hagan, J. The behavioural effects of corticotropin-releasing factor-related peptides in rats. Psychopharmacology (Berl) 138, 2 (1998), 124-132. 
[86] Kalamatianos, T., Grimshaw, S., Poorun, R., Hahn, J., and Coen, C. Fasting reduces kiss-1 expression in the anteroventral periventricular nucleus (avpv): effects of fasting on the expression of kiss- 1 and neuropeptide y in the avpv or arcuate nucleus of female rats. J Neuroendocrinol 20, 9 (2008), 1089-1097.

[87] Kalsbeek, A., van der Spek, R., Lei, J., Endert, E., Buiss, R., and Fliers, E. Circadian rhythms in the hypothalamo-pituitary-adrenal (hpa) axis. Mol Cell Endocrinol 349, 1 (2012), 20-29.

[88] Kauffman, A., Gottsch, M., Roa, J., Byquist, A., Crown, A., Clifton, D., Hoffman, G., Steiner, R., and Tena-Sempere, M. Sexual differentiation of kiss1 gene expression in the brain of the rat. Endocrinology 148, 4 (2007), 1774-1783.

[89] Kauffman, A., Park, J., McPhie-Lalmansingh, A., Gottsch, M., Bodo, C., Hohmann, J., Pavlova, M., Rohde, A., Clifton, D., Steiner, R., and Rissman, E. The kisspeptin receptor gpr54 is required for sexual differentiation of the brain and behavior. J Neurosci 27, 33 (2007), 8826-8835.

[90] Keen, K., Wegner, F., Bloom, S., Ghatei, M., and Terasawa, E. An increase in kisspeptin-54 release occurs with the pubertal increase in luteinizing hormone-releasing hormone-1 release in the stalk-median eminence of female rhesus monkeys in vivo. Endocrinology 149, 8 (2008), 4151-4157.

[91] Khan, A., And Kauffman, A. The role of kisspeptin and rfamide-related peptide-3 neurones in the circadian-timed preovulatory luteinising hormone surge. J Neuroendocrinol 24, 1 (2012), 131-143.

[92] Kinoshita, M., Tsukamura, H., Adachi, S., Matsui, H., Uenoyama, Y., Iwata, K., Yamada, S., Inoue, K., Ohtaki, T., Matsumoto, H., and Maeda, K. Involvement of central metastin in the regulation of preovulatory luteinizing hormone surge and estrous cyclicity in female rats. Endocrinology 146, 10 (2005), 4431-4436.

[93] Kinsey-Jones, J., Li, X., Knox, A., Wilkinson, E., Zhu, X., Chaudhary, A., MilLigan, S., Lightman, S., And O'Byrne, K. Down-regulation of hypothalamic kisspeptin and its receptor, kiss1r, mrna expression is associated with stress-induced suppression of luteinising hormone secretion in the female rat. J Neuroendocrinol 21, 1 (2009), 20-29.

[94] Kirby, H., Maguire, J., Colledge, W., and Davenport, A. International union of basic and clinical pharmacology. lxxvii. kisspeptin receptor nomenclature, distribution, and function. Pharmacol Rev 62, 4 (2010), 565-578.

[95] Klengel, T., Mehta, D., Anacker, C., Rex-Haffner, M., Pruessner, J., Pariante, C., Pace, T., Mercer, K., Mayberg, H., Bradley, B., Nemeroff, C., Holsboer, F., Heim, C., Ressler, K., Rein, T., And Binder, E. Allele-specific fkbp5 dna demethylation mediates gene-childhood trauma interactions. Nat Neurosci 16, 1 (2013), 33-41.

[96] Koob, G., And Heinrichs, S. A role for corticotropin releasing factor and urocortin in behavioral responses to stressors. Brain Res 848, 1-2 (1999), 141-152.

[97] Koob, G., and Thatcher-Britton, K. Stimulant and anxiogenic effects of corticotropin releasing factor. Prog Clin Biol Res 192 (1985), 499-506.

[98] Kotani, M., Detheux, M., Vandenbogaerde, A., Communi, D., Vanderwinden, J., Le Poul, E., Brezillon, S., Tyldesley, R., Suarez-Huerta, N., Vandeput, F., 
Blanpain, C., Schiffmann, S., Vassart, G., and Parmentier, M. The metastasis suppressor gene kiss-1 encodes kisspeptins, the natural ligands of the orphan g protein-coupled receptor gpr54. J Biol Chem 276, 37 (2001), 34631-34636.

[99] Kudielka, B., Buske-Kirschbaum, A., Hellhammer, D., and Kirschbaum, C. Hpa axis responses to laboratory psychosocial stress in healthy elderly adults, younger adults, and children: impact of age and gender. Psychoneuroendocrinology 29, 1 (2004), 83-98.

[100] Kuner, R. Central mechanisms of pathological pain. Nat Med 16, 11 (2010), 1258-1266.

[101] Lake, J., Hammond, M., Shaddox, R., Hunsicker, L., Yang, H., and Malin, D. Igg from neuropeptide ff antiserum reverses morphine tolerance in the rat. Neurosci Lett 132, 1 (1991), 29-32.

[102] Lameh, J., Bertozzi, F., Kelly, N., Jacobi, P., Nguyen, D., Bajpai, A., Gaubert, G., Olsson, R., And Gardell, L. Neuropeptide ff receptors have opposing modulatory effects on nociception. J Pharmacol Exp Ther 334, 1 (2010), 244-254.

[103] Landsberg, L., Young, J., Leonard, W., Linsenmeier, R., and Turek, F. Is obesity associated with lower body temperatures? core temperature: a forgotten variable in energy balance. Metabolism 58, 6 (2009), 871-876.

[104] Laurent, P., Becker, J., Valverde, O., Ledent, C., de Kerchove d’Exaerde, A., Schiffmann, S., Maldonado, R., Vassart, G., and Parmentier, M. The prolactinreleasing peptide antagonizes the opioid system through its receptor gpr10. Nat Neurosci 8, 12 (2005), 1735-1741.

[105] Lawrence, C., Ellacott, K., and Luckman, S. Prl-releasing peptide reduces food intake and may mediate satiety signaling. Endocrinology 143, 2 (2002), 360-367.

[106] Lee, D., Nguyen, T., O’Neill, G., Cheng, R., Liu, Y., Howard, A., Coulombe, N., Tan, C., Tang-Nguyen, A., George, S., And O'Dowd, B. Discovery of a receptor related to the galanin receptors. FEBS Lett 446, 1 (1999), 103-107.

[107] Lee, J., Miele, M., Hicks, D., Phillips, K., Trent, J., Weissman, B., And Welch, D. Kiss-1, a novel human malignant melanoma metastasis-suppressor gene. Journal of the National Cancer Institute 88, 23 (1996), 1731-1737.

[108] Lehman, M., Ladha, Z., Coolen, L., Hileman, S., Connors, J., and Goodman, R. Neuronal plasticity and seasonal reproduction in sheep. Eur J Neurosci 32, 12 (2010), $2152-2164$.

[109] Levine, A., Rogers, B., Kneip, J., Grace, M., and Morley, J. Effect of centrally administered corticotropin releasing factor (crf) on multiple feeding paradigms. Neuropharmacology 22, 3 (1983), 337-339.

[110] Li, X., Knox, A., And O'Byrne, K. Corticotrophin-releasing factor and stress-induced inhibition of the gonadotrophin-releasing hormone pulse generator in the female. Brain Res 1364 (2010), 153-163.

[111] Lightman, S., and Conway-Campbell, B. The crucial role of pulsatile activity of the hpa axis for continuous dynamic equilibration. Nat Rev Neurosci 11, 10 (2010), 710-718.

[112] Lin, S. Prolactin-releasing peptide. Results Probl Cell Differ 46 (2008), 57-88.

[113] Linthorst, A., And Reul, J. Stress and the brain: solving the puzzle using microdialysis. Pharmacol Biochem Behav 90, 2 (2008), 163-173. 
[114] Liu, Q., Guan, X., Martin, W., McDonald, T., Clements, M., Jiang, Q., Zeng, Z., Jacobson, M., Williams, D. J., Yu, H., Bomford, D., Figueroa, D., Mallee, J., Wang, R., Evans, J., Gould, R., And Austin, C. Identification and characterization of novel mammalian neuropeptide ff-like peptides that attenuate morphine-induced antinociception. J Biol Chem 276, 40 (2001), 36961-36969.

[115] Lomax, P., Bajorek, J., Chesarek, W., and Tataryn, I. Thermoregulatory effects of luteinizing hormone releasing hormone in the rat. Thermoregulatory mechanisms and their therapeutic implications, Karger, Basel (1980), 208-211.

[116] Lopez-Munoz, F., and Alamo, C. Monoaminergic neurotransmission: the history of the discovery of antidepressants from 1950s until today. Curr Pharm Des 15, 14 (2009), 15631586.

[117] Lowry, C., And Moore, F. Regulation of behavioral responses by corticotropin-releasing factor. Gen Comp Endocrinol 146, 1 (2006), 19-27.

[118] Lu, N., Wardell, S., Burnstein, K., Defranco, D., Fuller, P., Giguere, V., HochBerg, R., McKay, L., Renoir, J., Weigel, N., Wilson, E., McDonnell, D., And Cidlowski, J. International union of pharmacology. lxv. the pharmacology and classification of the nuclear receptor superfamily: glucocorticoid, mineralocorticoid, progesterone, and androgen receptors. Pharmacol Rev 58, 4 (2006), 782-797.

[119] Luque, R., Kineman, R., And Tena-Sempere, M. Regulation of hypothalamic expression of kiss-1 and gpr54 genes by metabolic factors: analyses using mouse models and a cell line. Endocrinology 148, 10 (2007), 4601-4611.

[120] Lutz, P., And Kieffer, B. Opioid receptors: distinct roles in mood disorders. Trends Neurosci 36, 3 (2013), 195-206.

[121] Lyubimov, Y., Engstrom, M., Wurster, S., Savola, J., Korpi, E., and Panula, P. Human kisspeptins activate neuropeptide ff2 receptor. Neuroscience 170, 1 (2010), 117-122.

[122] Maletinska, L., Ticha, A., Nagelova, V., Spolcova, A., Blechova, M., Elbert, T., AND Zelezna, B. Neuropeptide ff analog rf9 is not an antagonist of npff receptor and decreases food intake in mice after its central and peripheral administration. Brain Res (2013).

[123] Malin, D., Lake, J., Fowler, D., Hammond, M., Brown, S., Leyva, J., Prasco, P., AND Dougherty, T. Fmrf-nh2-like mammalian peptide precipitates opiate-withdrawal syndrome in the rat. Peptides 11, 2 (1990), 277-280.

[124] Malin, D., Lake, J., Smith, D., Jones, J., Morel, J., Claunch, A., Stevens, P., PAYZA, K., Ho, K., LiU, J., AND ET, A. Subcutaneous injection of an analog of neuropeptide ff prevents naloxone-precipitated morphine abstinence syndrome. Drug Alcohol Depend 40, 1 (1995), 37-42.

[125] Marek, G., Martin-Ruiz, R., Abo, A., and Artigas, F. The selective 5-ht2a receptor antagonist m100907 enhances antidepressant-like behavioral effects of the ssri fluoxetine. Neuropsychopharmacology 30, 12 (2005), 2205-2215.

[126] Martin, C., Navarro, V., Simavli, S., Vong, L., Carroll, R., Lowell, B., and KAISER, U. Leptin-responsive gabaergic neurons regulate fertility through pathways that result in reduced kisspeptinergic tone. J Neurosci 34, 17 (2014), 6047-6056. 
[127] Martin, E., Ressler, K., Binder, E., And Nemeroff, C. The neurobiology of anxiety disorders: brain imaging, genetics, and psychoneuroendocrinology. Psychiatr Clin North Am 32, 3 (2009), 549-575.

[128] Martini, A., Fernandez-Fernandez, R., Tovar, S., Navarro, V., Vigo, E., Vazquez, M., Davies, J., Thompson, N., Aguilar, E., Pinilla, L., Wells, T., Dieguez, C., And Tena-Sempere, M. Comparative analysis of the effects of ghrelin and unacylated ghrelin on luteinizing hormone secretion in male rats. Endocrinology 147, 5 (2006), $2374-2382$.

[129] Matsumoto, H., Maruyama, M., Noguchi, J., Horikoshi, Y., Fujiwara, K., Kitada, C., Hinuma, S., Onda, H., Nishimura, O., Inoue, K., and Fujino, M. Stimulation of corticotropin-releasing hormone-mediated adrenocorticotropin secretion by central administration of prolactin-releasing peptide in rats. Neurosci Lett 285, 3 (2000), 234-238.

[130] Matsumaki, T., Kayasuga, Y., Yamanouchi, K., and Nishinara, M. Maintenance of gonadotropin secretion by glucocorticoids under stress conditions through the inhibition of prostaglandin synthesis in the brain. Endocrinology 147, 3 (2006), 1087-1093.

[131] Matsuwaki, T., Suzuki, M., Yamanouchi, K., and Nishihara, M. Glucocorticoid counteracts the suppressive effect of tumor necrosis factor-alpha on the surge of luteinizing hormone secretion in rats. $J$ Endocrinol 181, 3 (2004), 509-513.

[132] Matsuzaka, H., Maeshima, H., Kida, S., Kurita, H., Shimano, T., Nakano, Y., Baba, H., Suzuki, T., And Arai, H. Gender differences in serum testosterone and cortisol in patients with major depressive disorder compared with controls. Int J Psychiatry Med 46 , 2 (2013), 203-221.

[133] McEwen, B. Protective and damaging effects of stress mediators. $N$ Engl J Med 338, 3 (1998), 171-179.

[134] McEwen, B. Stress, adaptation, and disease. allostasis and allostatic load. Ann N Y Acad Sci 840 (1998), 33-44.

[135] McEwen, B. Physiology and neurobiology of stress and adaptation: central role of the brain. Physiol Rev 87, 3 (2007), 873-904.

[136] Mead, E., Maguire, J., Kuc, R., and Davenport, A. Kisspeptins are novel potent vasoconstrictors in humans, with a discrete localization of their receptor, g protein-coupled receptor 54, to atherosclerosis-prone vessels. Endocrinology 148, 1 (2007), 140.

[137] Menke, A., Krengel, T., Rubel, J., Bruckl, T., Pfister, H., Lucae, S., Uhr, M., Holsboer, F., And Binder, E. Genetic variation in fkbp5 associated with the extent of stress hormone dysregulation in major depression. Genes Brain Behav 12, 3 (2013), 289-296.

[138] Messager, S., Chatzidaki, E., Ma, D., Hendrick, A., Zahn, D., Dixon, J., Thresher, R., Malinge, I., lomet, D., Carlton, M., Colledge, W., Caraty, A., AND APARICIO, S. Kisspeptin directly stimulates gonadotropin-releasing hormone release via g protein-coupled receptor 54. Proc Natl Acad Sci U S A 102, 5 (2005), 1761-1766.

[139] Meyer, J., Mcmain, S., Kennedy, S., Korman, L., Brown, G., DaSilva, J., Wilson, A., Blak, T., Eynan-Harvey, R., Goulding, V., Houle, S., and Links, P. Dysfunctional attitudes and 5-ht2 receptors during depression and self-harm. Am J Psychiatry 160, 1 (2003), 90-99. 
[140] Mi, W., Mao-Ying, Q., Liu, Q., Wang, X., Li, X., Wang, Y., and Wu, G. The distribution of kisspeptin and its receptor gpr54 in rat dorsal root ganglion and up-regulation of its expression after cfa injection. Brain Res Bull 78, 4-5 (2009), 254-260.

[141] Min, L., Soltis, K., Reis, A., Xu, S., Kuohung, W., Jain, M., Carroll, R., And KAISER, U. Dynamic kisspeptin receptor trafficking modulates kisspeptin-mediated calcium signaling. Mol Endocrinol 28, 1 (2014), 16-27.

[142] Mitsushima, D., Yamada, K., Takase, K., Funabashi, T., and Kimura, F. Sex differences in the basolateral amygdala: the extracellular levels of serotonin and dopamine, and their responses to restraint stress in rats. Eur J Neurosci 24, 11 (2006), 3245-3254.

[143] Mogil, J., Sternberg, W., Kest, B., Marek, P., And Liebeskind, J. Sex differences in the antagonism of swim stress-induced analgesia: effects of gonadectomy and estrogen replacement. Pain 53, 1 (1993), 17-25.

[144] Moore, R., And Eichler, V. Loss of a circadian adrenal corticosterone rhythm following suprachiasmatic lesions in the rat. Brain Res 42, 1 (1972), 201-206.

[145] Morilak, D., Barrera, G., Echevarria, D., Garcia, A., Hernandez, A., Ma, S., And Petre, C. Role of brain norepinephrine in the behavioral response to stress. Prog Neuropsychopharmacol Biol Psychiatry 29, 8 (2005), 1214-1224.

[146] Morio, H., Tatsuno, I., Hirai, A., Tamura, Y., and Saito, Y. Pituitary adenylate cyclase-activating polypeptide protects rat-cultured cortical neurons from glutamate-induced cytotoxicity. Brain Res 741, 1-2 (1996), 82-88.

[147] Mouledous, L., Froment, C., Dauvillier, S., Burlet-Schiltz, O., Zajac, J., And Mollereau, C. Grk2 protein-mediated transphosphorylation contributes to loss of function of mu-opioid receptors induced by neuropeptide ff (npff2) receptors. J Biol Chem 287, 16 (2012), 12736-12749.

[148] Muir, A., Chamberlain, L., Elshourbagy, N., Michalovich, D., Moore, D., Calamari, A., Szekeres, P., Sarau, H., Chambers, J., Murdock, P., Steplewski, K., Shabon, U., Miller, J., Middleton, S., Darker, J., Larminie, C., Wilson, S., Bergsma, D., Emson, P., Faull, R., Philpott, K., And Harrison, D. Axor12, a novel human g protein-coupled receptor, activated by the peptide kiss-1. J Biol Chem 276, 31 (2001), 28969-28975.

[149] Muller, M., Zimmermann, S., Sillaber, I., Hagemeyer, T., Deussing, J., Timpl, P., Kormann, M., Droste, S., Kuhn, R., Reul, J., Holsboer, F., And Wurst, W. Limbic corticotropin-releasing hormone receptor 1 mediates anxiety-related behavior and hormonal adaptation to stress. Nat Neurosci 6, 10 (2003), 1100-1107.

[150] Nakamura, K. Central circuitries for body temperature regulation and fever. Am J Physiol Regul Integr Comp Physiol 301, 5 (2011), R1207-R1228.

[151] Nappi, C., Petraglia, F., Gambardella, A., De Masellis, G., Di Carlo, C., Genazzani, A., And Montemagno, U. Relationship between cerebrospinal fluid betaendorphin and plasma pituitary-gonadal hormone levels in women. J Endocrinol Invest 13, 2 (1990), 149-153.

[152] Navarro, V., Castellano, J., Fernandez-Fernandez, R., Barreiro, M., Roa, J., Sanchez-Criado, J., Aguilar, E., Dieguez, C., Pinilla, L., and Tena-Sempere, M. 
Developmental and hormonally regulated messenger ribonucleic acid expression of kiss-1 and its putative receptor, gpr54, in rat hypothalamus and potent luteinizing hormone-releasing activity of kiss-1 peptide. Endocrinology 145, 10 (2004), 4565-4574.

[153] Navarro, V., Castellano, J., Fernandez-Fernandez, R., Tovar, S., Roa, J., Mayen, A., Nogueiras, R., Vazquez, M., Barreiro, M., Magni, P., Aguilar, E., Dieguez, C., Pinilla, L., And Tena-Sempere, M. Characterization of the potent luteinizing hormone-releasing activity of kiss-1 peptide, the natural ligand of gpr54. Endocrinology 146, 1 (2005), 156-163.

[154] Navarro, V., FernándezâĂ̌̌fernández, R., Castellano, J., Roa, J., Mayen, A., Barreiro, M., Gaytan, F., Aguilar, E., Pinilla, L., And Dieguez, C. Advanced vaginal opening and precocious activation of the reproductive axis by kissâĂ $\check{R} 1$ peptide, the endogenous ligand of gpr54. The Journal of physiology 561, 2 (2004), 379-386.

[155] Navarro, V., Gottsch, M., Chavkin, C., Okamura, H., Clifton, D., AND Steiner, R. Regulation of gonadotropin-releasing hormone secretion by kisspeptin/dynorphin/neurokinin b neurons in the arcuate nucleus of the mouse. J Neurosci 29, 38 (2009), 11859-11866.

[156] Neumann, I., And Landgraf, R. Balance of brain oxytocin and vasopressin: implications for anxiety, depression, and social behaviors. Trends Neurosci 35, 11 (2012), 649-659.

[157] Oakley, A., Clifton, D., And Steiner, R. Kisspeptin signaling in the brain. Endocrine reviews 30, 6 (2009), 713-743.

[158] Ohtaki, T., Shintani, Y., Honda, S., Matsumoto, H., Hori, A., Kanehashi, K., Terao, Y., Kumano, S., Takatsu, Y., Masuda, Y., Ishibashi, Y., Watanabe, T., Asada, M., Yamada, T., Suenaga, M., Kitada, C., Usuki, S., Kurokawa, T., Onda, H., Nishimura, O., And Fujino, M. Metastasis suppressor gene kiss-1 encodes peptide ligand of a g-protein-coupled receptor. Nature 411, 6837 (2001), 613-617.

[159] Oitzl, M., Fluttert, M., Sutanto, W., And de Kloet, E. Continuous blockade of brain glucocorticoid receptors facilitates spatial learning and memory in rats. Eur J Neurosci 10, 12 (1998), 3759-3766.

[160] OKa, T., Oka, K., AND Hori, T. Mechanisms and mediators of psychological stress-induced rise in core temperature. Psychosom Med 63, 3 (2001), 476-486.

[161] Onaka, T., Takayanagi, Y., And Leng, G. Metabolic and stress-related roles of prolactinreleasing peptide. Trends Endocrinol Metab 21, 5 (2010), 287-293.

[162] Palkovits, M., Baffi, J., And PACAK, K. The role of ascending neuronal pathways in stress-induced release of noradrenaline in the hypothalamic paraventricular nucleus of rats. $J$ Neuroendocrinol 11, 7 (1999), 529-539.

[163] Paller, C., Campbell, C., Edwards, R., and Dobs, A. Sex-based differences in pain perception and treatment. Pain Med 10, 2 (2009), 289-299.

[164] Pandey, D., Mahesh, R., Kumar, A., Rao, V., Arjun, M., and Rajkumar, R. A novel 5-ht (2a) receptor antagonist exhibits antidepressant-like effects in a battery of rodent behavioural assays: approaching early-onset antidepressants. Pharmacol Biochem Behav 94, 3 (2010), 363-373. 
[165] Panula, P., Kalso, E., Nieminen, M., Kontinen, V., Brandt, A., And Pertovaara, A. Neuropeptide ff and modulation of pain. Brain Res 848, 1-2 (1999), 191-196.

[166] Patel, J., Bartoszyk, G., Edwards, E., And Ashby, C. J. The highly selective 5hydroxytryptamine (5-ht)2a receptor antagonist, emd 281014, significantly increases swimming and decreases immobility in male congenital learned helpless rats in the forced swim test. Synapse 52, 1 (2004), 73-75.

[167] Paxinos, G., And Franklin, K. The Mouse Brain in Stereotaxic Coordinates. Academic Press, London, 2012.

[168] Pelka-Wysiecka, J., Zietek, J., Grzywacz, A., Kucharska-Mazur, J., BienKOWski, P., AND SAmochowiec, J. Association of genetic polymorphisms with personality profile in individuals without psychiatric disorders. Prog Neuropsychopharmacol Biol Psychiatry 39, 1 (2012), 40-46.

[169] Pezet, S., And McMahon, S. Neurotrophins: mediators and modulators of pain. Annu Rev Neurosci 29 (2006), 507-538.

[170] Picciotto, M., Brabant, C., Einstein, E., Kamens, H., and Neugebauer, N. Effects of galanin on monoaminergic systems and hpa axis: Potential mechanisms underlying the effects of galanin on addiction- and stress-related behaviors. Brain Res 1314 (2010), 206-218.

[171] Pineda, R., Aguilar, E., Pinilla, L., And Tena-Sempere, M. Physiological roles of the kisspeptin/gpr54 system in the neuroendocrine control of reproduction. Prog Brain Res 181 (2010), 55-77.

[172] Pineda, R., Garcia-Galiano, D., Roseweir, A., Romero, M., Sanchez-Garrido, M., Ruiz-Pino, F., Morgan, K., Pinilla, L., Millar, R., and Tena-Sempere, M. Critical roles of kisspeptins in female puberty and preovulatory gonadotropin surges as revealed by a novel antagonist. Endocrinology 151, 2 (2010), 722-730.

[173] Pliska, V. Models to explain dose-response relationships that exhibit a downturn phase. Trends Pharmacol Sci 15, 6 (1994), 178-181.

[174] Price, D., And Greenberg, M. Structure of a molluscan cardioexcitatory neuropeptide. Science 197, 4304 (1977), 670-671.

[175] Purves, H., And Sirett, N. Assay of corticotrophin in dexamethasone-treated rats. Endocrinology 7\%, 2 (1965), 366.

[176] Qiu, X., Dowling, A., Marino, J., Faulkner, L., Bryant, B., Bruning, J., Elias, C., AND Hill, J. Delayed puberty but normal fertility in mice with selective deletion of insulin receptors from kiss1 cells. Endocrinology 154, 3 (2013), 1337-1348.

[177] Quennell, J., Mulligan, A., Tups, A., Liu, X., Phipps, S., Kemp, C., Herbison, A., Grattan, D., And Anderson, G. Leptin indirectly regulates gonadotropin-releasing hormone neuronal function. Endocrinology 150, 6 (2009), 2805-2812.

[178] Ramaswamy, S., Gibbs, R., And Plant, T. Studies of the localisation of kisspeptin within the pituitary of the rhesus monkey (macaca mulatta) and the effect of kisspeptin on the release of non-gonadotropic pituitary hormones. J Neuroendocrinol 21, 10 (2009), 795-804.

[179] Ramaswamy, S., Guerriero, K., Gibbs, R., and Plant, T. Structural interactions between kisspeptin and gnrh neurons in the mediobasal hypothalamus of the male rhesus monkey (macaca mulatta) as revealed by double immunofluorescence and confocal microscopy. Endocrinology 149, 9 (2008), 4387-4395. 
[180] RaO, Y., MotT, N., AND PAK, T. Effects of kisspeptin on parameters of the hpa axis. Endocrine (2011), 1-9.

[181] Richard, N., Corvaisier, S., Camacho, E., And Kottler, M. Kiss-1 and gpr54 at the pituitary level: overview and recent insights. Peptides 30, 1 (2009), 123-129.

[182] Rivier, C., AND VALE, W. Interaction of corticotropin-releasing factor and arginine vasopressin on adrenocorticotropin secretion in vivo. Endocrinology 113, 3 (1983), 939.

[183] Roa, J., Navarro, V., And Tena-Sempere, M. Kisspeptins in reproductive biology: consensus knowledge and recent developments. Biol Reprod 85, 4 (2011), 650-660.

[184] Rosenspire, A., Kindzelskit, A., And Petty, H. Cutting edge: fever-associated temperatures enhance neutrophil responses to lipopolysaccharide: a potential mechanism involving cell metabolism. J Immunol 169, 10 (2002), 5396-5400.

[185] Roumy, M., Lorenzo, C., Mazeres, S., Bouchet, S., Zajac, J., And Mollereau, C. Physical association between neuropeptide ff and micro-opioid receptors as a possible molecular basis for anti-opioid activity. J Biol Chem 282, 11 (2007), 8332-8342.

[186] Roy, B., Reid, R., And VAn Vugt, D. The effects of estrogen and progesterone on corticotropin-releasing hormone and arginine vasopressin messenger ribonucleic acid levels in the paraventricular nucleus and supraoptic nucleus of the rhesus monkey. Endocrinology 140, 5 (1999), 2191.

[187] Sanchez-Garrido, M., Ruiz-Pino, F., Manfredi-Lozano, M., Leon, S., GarciaGaliano, D., Castano, J., Luque, R., Romero-Ruiz, A., Castellano, J., Dieguez, C., Pinilla, L., And Tena-Sempere, M. Obesity-induced hypogonadism in the male: premature reproductive neuroendocrine senescence and contribution of kiss1-mediated mechanisms. Endocrinology 155, 3 (2014), 1067-1079.

[188] Saper, C., Lu, J., Chou, T., And Gooley, J. The hypothalamic integrator for circadian rhythms. Trends Neurosci 28, 3 (2005), 152-157.

[189] Sara, S. The locus coeruleus and noradrenergic modulation of cognition. Nat Rev Neurosci 10,3 (2009), 211-223.

[190] Scharf, S., Liebl, C., Binder, E., Schmidt, M., And Muller, M. Expression and regulation of the fkbp5 gene in the adult mouse brain. PLoS One 6, 2 (2011), e16883.

[191] Schildkraut, J. The catecholamine hypothesis of affective disorders: a review of supporting evidence. Am J Psychiatry 122, 5 (1965), 509-522.

[192] ScotT, V., AND Brown, C. Kisspeptin activation of supraoptic nucleus neurons in vivo. Endocrinology 152, 10 (2011), 3862-3870.

[193] SELye, H. Forty years of stress research: principal remaining problems and misconceptions. Can Med Assoc J 115, 1 (1976), 53-56.

[194] Seminara, S., Messager, S., Chatzidaki, E., Thresher, R., Acierno, J. J., Shagoury, J., Bo-Abbas, Y., Kuohung, W., Schwinof, K., Hendrick, A., Zahn, D., Dixon, J., Kaiser, U., Slaugenhaupt, S., Gusella, J., O’Rahilly, S., Carlton, M., Crowley, W. J., Aparicio, S., and Colledge, W. The gpr54 gene as a regulator of puberty. N Engl J Med 349, 17 (2003), 1614-1627. 
[195] Serova, L., Tillinger, A., Alaluf, L., Laukova, M., Keegan, K., and Sabban, E. Single intranasal neuropeptide y infusion attenuates development of ptsd-like symptoms to traumatic stress in rats. Neuroscience 236 (2013), 298-312.

[196] Shahab, M., Mastronardi, C., Seminara, S., Crowley, W., Ojeda, S., and Plant, T. Increased hypothalamic gpr54 signaling: a potential mechanism for initiation of puberty in primates. Proc Natl Acad Sci U S A 102, 6 (2005), 2129-2134.

[197] Shelton, R., Sanders-Bush, E., Manier, D., And Lewis, D. Elevated 5-ht 2a receptors in postmortem prefrontal cortex in major depression is associated with reduced activity of protein kinase a. Neuroscience 158, 4 (2009), 1406-1415.

[198] Sherman, J., And Kalin, N. The effects of icv-crh on novelty-induced behavior. Pharmacol Biochem Behav 26, 4 (1987), 699-703.

[199] Silberman, Y., And Winder, D. Emerging role for corticotropin releasing factor signaling in the bed nucleus of the stria terminalis at the intersection of stress and reward. Front Psychiatry 4 (2013), 42.

[200] SiRinathsinghu, D. Inhibitory influence of corticotropin releasing factor on components of sexual behaviour in the male rat. Brain Res 407, 1 (1987), 185-190.

[201] Smarr, B., Morris, E., And de la Iglesia, H. The dorsomedial suprachiasmatic nucleus times circadian expression of kiss1 and the luteinizing hormone surge. Endocrinology 153, 6 (2012), 2839-2850.

[202] Smith, J., Acohido, B., Clifton, D., And Steiner, R. Kiss-1 neurones are direct targets for leptin in the ob/ob mouse. J Neuroendocrinol 18, 4 (2006), 298-303.

[203] Smith, J., Cunningham, M., Rissman, E., Clifton, D., And Steiner, R. Regulation of kiss1 gene expression in the brain of the female mouse. Endocrinology 146, 9 (2005), 3686-3692.

[204] Smith, J., Dungan, H., Stoll, E., Gottsch, M., Braun, R., Eacker, S., Clifton, D., AND Steiner, R. Differential regulation of kiss-1 mrna expression by sex steroids in the brain of the male mouse. Endocrinology 146, 7 (2005), 2976-2984.

[205] Smith, J., Rao, A., Pereira, A., Caraty, A., Millar, R., and Clarke, I. Kisspeptin is present in ovine hypophysial portal blood but does not increase during the preovulatory luteinizing hormone surge: evidence that gonadotropes are not direct targets of kisspeptin in vivo. Endocrinology 149, 4 (2008), 1951.

[206] Spampinato, S., Trabucco, A., Biasiotta, A., Biagioni, F., Cruccu, G., Copani, A., Colledge, W., Sortino, M., Nicoletti, F., And Chiechio, S. Hyperalgesic activity of kisspeptin in mice. Mol Pain 7 (2011), 90.

[207] Spinazzi, R., Andreis, P., Rossi, G., And Nussdorfer, G. Orexins in the regulation of the hypothalamic-pituitary-adrenal axis. Pharmacol Rev 58, 1 (2006), 46-57.

[208] Stengel, A., Wang, L., Goebel-Stengel, M., And Tache, Y. Centrally injected kisspeptin reduces food intake by increasing meal intervals in mice. Neuroreport 22, 5 (2011), $253-257$.

[209] Sternberg, W., Smith, L., and Scorr, L. Nociception and antinociception during the first week of life in mice: sex differences and test dependence. J Pain 5, 8 (2004), 420-426. 
[210] Sutton, R., Koob, G., Le Moal, M., Rivier, J., and Vale, W. Corticotropin releasing factor produces behavioural activation in rats. Nature 297, 5864 (1982), 331-333.

[211] Swanson, L., And Sawchenko, P. Hypothalamic integration: organization of the paraventricular and supraoptic nuclei. Annu Rev Neurosci 6 (1983), 269-324.

[212] Szekely, M., Petervari, E., and Balasko, M. Thermoregulation, energy balance, regulatory peptides: recent developments. Front Biosci (Schol Ed) 2 (2010), 1009-1046.

[213] Sztainberg, Y., And Chen, A. Neuropeptide regulation of stress-induced behavior: Insights from the crf/urocortin family. In Handbook of Neuroendocrinology, G. Fink, D. Pfaff, and J. Levine, Eds. Academic Press, Elsevier, London, Waltham, San Diego, 2012, pp. 355-376.

[214] Takayanagi, Y., And Onaka, T. Roles of prolactin-releasing peptide and rfamide related peptides in the control of stress and food intake. FEBS J 277, 24 (2010), 4998-5005.

[215] Telegdy, G., And Adamik, A. The action of kisspeptin-13 on passive avoidance learning in mice. involvement of transmitters. Behav Brain Res 243 (2013), 300-305.

[216] Teles, M., Bianco, S., Brito, V., Trarbach, E., Kuohung, W., Xu, S., Seminara, S., Mendonca, B., Kaiser, U., and Latronico, A. A gpr54-activating mutation in a patient with central precocious puberty. $N$ Engl J Med 358, 7 (2008), 709-715.

[217] Tena-Sempere, M. Kisspeptins. In Handbook of Biologically Active Peptides, J. Kastin, Ed. Academic Press, Boston, 2013, pp. 819-827.

[218] Ulrich-Lai, Y., and Herman, J. Neural regulation of endocrine and autonomic stress responses. Nat Rev Neurosci 10, 6 (2009), 397-409.

[219] Unruh, A. Gender variations in clinical pain experience. Pain 65, 2-3 (1996), 123-167.

[220] Van Pett, K., Viau, V., Bittencourt, J., Chan, R., Li, H., Arias, C., Prins, G., Perrin, M., Vale, W., and Sawchenko, P. Distribution of mrnas encoding crf receptors in brain and pituitary of rat and mouse. J Comp Neurol 428, 2 (2000), 191-212.

[221] Vegiopoulos, A., And Herzig, S. Glucocorticoids, metabolism and metabolic diseases. Mol Cell Endocrinol 275, 1-2 (2007), 43-61.

[222] Viau, V., Lee, P., Sampson, J., and Wu, J. A testicular influence on restraint-induced activation of medial parvocellular neurons in the paraventricular nucleus in the male rat. Endocrinology 144, 7 (2003), 3067.

[223] Viau, V., and Meaney, M. Testosterone-dependent variations in plasma and intrapituitary corticosteroid binding globulin and stress hypothalamic-pituitary-adrenal activity in the male rat. Journal of endocrinology 181, 2 (2004), 223.

[224] Vrang, N., Larsen, P., and Mikkelsen, J. Direct projection from the suprachiasmatic nucleus to hypophysiotrophic corticotropin-releasing factor immunoreactive cells in the paraventricular nucleus of the hypothalamus demonstrated by means of phaseolus vulgarisleucoagglutinin tract tracing. Brain Res 684, 1 (1995), 61-69.

[225] Walf, A., AND Frye, C. The use of the elevated plus maze as an assay of anxiety-related behavior in rodents. Nature protocols 2, 2 (2007), 322-328.

[226] Walker, R. Neuroactive peptides with an rfamide or famide carboxyl terminal. Comp Biochem Physiol C 102, 2 (1992), 213-222. 
[227] Waxman, A., Juni, A., Kowalczyk, W., Arout, C., Sternberg, W., and Kest, B. Progesterone rapidly recruits female-typical opioid-induced hyperalgesic mechanisms. Physiol Behav 101, 5 (2010), 759-763.

[228] Weiser, M., AND HANDA, R. Estrogen impairs glucocorticoid dependent negative feedback on the hypothalamic-pituitary-adrenal axis via estrogen receptor alpha within the hypothalamus. Neuroscience 159, 2 (2009), 883-895.

[229] Williams, J., Ingram, S., Henderson, G., Chavkin, C., von Zastrow, M., Schulz, S., Koch, T., Evans, C., And Christie, M. Regulation of mu-opioid receptors: desensitization, phosphorylation, internalization, and tolerance. Pharmacol Rev 65, 1 (2013), 223-254.

[230] Woolf, C., And Salter, M. Neuronal plasticity: increasing the gain in pain. Science 288, 5472 (2000), 1765-1769.

[231] Yang, H., And IAdarola, M. Modulatory roles of the npff system in pain mechanisms at the spinal level. Peptides 27, 5 (2006), 943-952.

[232] Zenker, N., And Bernstein, D. The estimation of small amounts of corticosterone in rat plasma. The Journal of biological chemistry 231, 2 (1958), 695. 
Appendix 
Research report

\title{
Effects of kisspeptin-13 on the hypothalamic-pituitary-adrenal axis, thermoregulation, anxiety and locomotor activity in rats
}

\author{
Krisztina Csabafi a,*, Miklós Jászberényi ${ }^{\mathrm{a}}$, Zsolt Bagosi ${ }^{\mathrm{a}}$, Nándor Lipták ${ }^{\mathrm{a}}$, Gyula Telegdy a,b \\ a Department of Pathophysiology, University of Szeged, P.O. Box 427, H-6701 Szeged, Hungary \\ ${ }^{\mathrm{b}}$ Neuroscience Research Group of the Hungarian Academy of Sciences, P.O. Box 521, H-6701 Szeged, Hungary
}

\section{H I G H L I G H T S}

- Effects of kisspeptin-13 on the HPA axis, temperature and behavior were studied.

- Kisspeptin-13 activated the HPA axis in rats.

- Also stimulated spontaneous locomotor activity, exploratory behavior and anxiety.

- Furthermore, kisspeptin-13 induced hyperthermia.

\section{A R T I C L E I N F O}

\section{Article history:}

Received 31 August 2012

Received in revised form 9 November 2012

Accepted 26 November 2012

Available online 3 December 2012

\section{Keywords:}

Kisspeptin

Locomotor activity

Hyperthermia

Hypothalamic-pituitary-adrenal axis

\begin{abstract}
A B S T R A C T
Kisspeptin is a mammalian amidated neurohormone, which belongs to the RF-amide peptide family and is known for its key role in reproduction. However, in contrast with the related members of the RFamide family, little information is available regarding its role in the stress-response. With regard to the recent data suggesting kisspeptin neuronal projections to the paraventricular nucleus, in the present experiments we investigated the effect of kisspeptin-13 (KP-13), an endogenous derivative of kisspeptin, on the hypothalamus-pituitary-adrenal (HPA) axis, motor behavior and thermoregulatory function. The peptide was administered intracerebroventricularly (icv.) in different doses $(0.5-2 \mu \mathrm{g}$ ) to adult male Sprague-Dawley rats, the behavior of which was then observed by means of telemetry, open field and elevated plus maze tests. Additionally, plasma concentrations of corticosterone were measured in order to assess the influence of KP-13 on the HPA system. The effects on core temperature were monitored continuously via telemetry. The results demonstrated that KP-13 stimulated the horizontal locomotion (square crossing) in the open field test and decreased the number of entries into and the time spent in the open arms during the elevated plus maze tests. The peptide also caused marked elevations in the spontaneous locomotor activity and the core temperature recorded by the telemetric system, and significantly increased the basal corticosterone level. In conclusion, our data indicate that icv. administered KP-13 stimulates the HPA axis, induces hyperthermia, activates motor behavior and causes anxiety in rats.
\end{abstract}

(c) 2012 Elsevier B.V. All rights reserved.

\section{Introduction}

Kisspeptin, classified as a member of the Arg-Phe (RF)-amide family [1], is a C-terminally amidated neurohormone and is a key regulator of the hypothalamic-pituitary-gonadal (HPG) axis [2-4]. The kisspeptin related peptides are neuropeptide FF and AF, prolactin releasing peptide (PrRP), RFamide-related peptides, and the most recently found, pyroglutamylated RFamide peptide [1]. They

* Corresponding author at: Department of Pathophysiology, University of Szeged, H-6701 Szeged, Semmelweis u. 1, P.O. Box 427, Hungary. Tel.: +36 62 545994; fax: +36 62545710 .

E-mail address: csabafi.krisztina@med.u-szeged.hu (K. Csabafi). all share an N-terminal sequence homology and are widely distributed in the CNS, but they vary in their structure and receptor preference [1] binding to either one or several G-protein coupled receptors [5]. Literature shows that the effects of RF-amide peptides partially overlap, but in case of some physiological parameters they exert opposite actions. For example, PrRP activates the hypothalamic-pituitary-adrenal (HPA) axis [6], increases stereotyped locomotion [7] and pressor response [8]. Neuropepide AF (NPAF) also induces the HPA axis and locomotor activity, however, it causes a decrease in heart rate and core temperature [9]. Thus, in light of the above-mentioned data, kisspeptin might also have a wider range of function then so far assumed and may influence the same biological parameters as other RF-amide peptides. 
Kisspeptin, itself, was first isolated from the human placenta as the endogenous ligand of the orphan G-protein coupled receptor GPR54, later designated as KISS1R [10,11]. Kisspeptin is the product of the KiSS-1 gene; the peptide consists of 54 aminoacids (KP-54), but its cleavage can give rise to biologically active derivatives containing 14,13 or 10 aminoacids, christened kisspeptin-14 (KP-14), kisspeptin-13 (KP-13) and kisspeptin-10 (KP-10), respectively $[2,10]$. Kisspeptin and its receptor are abundant in the central nervous system (CNS), especially in the limbic system, the striatum, the pituitary and the hypothalamus, including the paraventricular nucleus (PVN) [10,12-14]. Recent evidence suggests that kisspeptin, beside the KISS1R, also activates the neuropeptide FF2 receptor [15], which mediates autonomic, endocrine, behavioral and nociceptive processes $[9,16]$.

The first biological action associated with kisspeptin was the suppression of metastasis in melanoma [17], but recently a number of publications $[4,18,19]$ has demonstrated the pivotal role of the kisspeptin system in the regulation of the reproductive axis. Kisspeptin is necessary for the normal secretion of gonadotropin releasing hormone (GnRH) $[20,21]$ and subsequently luteinizing hormone ( $\mathrm{LH}$ ) and follicle-stimulating hormone (FSH) [21], meanwhile, it may also control the onset of puberty $[20,22]$ through its activity on the biological clock of the CNS $[23,24]$. These seemingly disparate activities can be attributed to the ability of the peptide to stimulate diverse intracellular signal transduction cascades involving the activation of phospholipase C (PLC), mitogen activated protein kinase (MAPK), calcineurin and NFKB [25]. These pathways can influence hormone secretion, chemotaxis, and the organization of the cytoskeleton, neuronal activity and plasticity [24-26].

Taking the special importance of kisspeptin in the regulation of the HPG axis into account, and the fact that recent data suggests kisspeptin neuronal projections to the PVN [13,27], it seems plausible that kisspeptin may take part in the control of the HPA axis, the interaction between the two systems and may exert further integrative activities in autonomic and endocrine control.

Therefore, in the present study, we investigated the central action of KP-13 on the stress response, behavior and thermoregulation, which are processes controlled by the hypothalamus and the limbic system, where kisspeptin and its receptors are found in abundance [13]. As an index of the activation of the HPA system the corticosterone response was used. The spontaneous locomotion and core temperature were monitored continuously with a telemetric system, while the exploratory and anxiety-associated behavior was observed in open field and elevated plus maze tests.

\section{Materials and methods}

\subsection{Animals}

Adult male Sprague-Dawley rats (Domaszék, Hungary) weighing 150-250 were used at the age of 8 weeks. They were housed under controlled conditions (12/12-h light/dark cycle, lights on from 6:00 a.m. at constant room temperature) and were allowed free access to commercial food and tap water. The animals were kept and handled during the experiments in accordance with the instructions of the University of Szeged Ethical Committee for the Protection of Animals in Research, which approved these experiments. Approximately 160 animals in total were used in our experiments. Every experiment was carried out separately; the same animal has never been used for different experimental procedure.

\subsection{Surgery}

The animals were allowed 1 week to acclimatize before surgery. Subsequently, they were implanted with a stainless steel Luer cannula $(10 \mathrm{~mm}$ long) aimed at the right lateral cerebral ventricle under pentobarbital $(35 \mathrm{mg} / \mathrm{kg}$, intraperitoneally) anesthesia. The stereotaxic coordinates were $0.2 \mathrm{~mm}$ posterior and $1.7 \mathrm{~mm}$ latera to the bregma, and $3.7 \mathrm{~mm}$ deep from the dural surface, according to the atlas of Pellegrino et al. [28]. The cannula was secured to the skull with dental cement and acrylate. The rats were used after a recovery period of 5 days. All experiments were carried out between 8:00 and 10:00 a.m.
For implantation of the telemetric radio transmitter (E-Mitter: a temperatureactivity transponder), the rats were anesthetized with pentobarbital $(35 \mathrm{mg} / \mathrm{kg}$ intraperitoneally). The abdomen was opened by making a $2-\mathrm{cm}$ midline incision along the linea alba. The E-Mitter was placed in the abdominal cavity, along the sagittal plane, in front of the caudal arteries and veins, but dorsal to the digestive organs. The abdominal wound was then closed with absorbable suture material, while the skin was closed with stainless steel suture clips. After a recovery period of 5 days, the rats were implanted with the stainless steel Luer cannula for intracerebroventricula (icv.) administration.

At the end of the experiments, the correct position and the permeability of the cannula were checked. In the behavioral studies, each rat was sacrificed unde pentobarbital anesthesia, and in the endocrinological experiments the head was collected after decapitation. Methylene blue was injected via the implanted cannula and the brains were then dissected. Only data from animals exhibiting the diffusion of methylene blue in all the ventricles were included in the statistical evaluation.

\subsection{Treatment}

Rats were injected with different doses of KP-13 (Bachem Ltd., Switzerland) icv. in a volume of $2 \mu \mathrm{l}$ over 30 s with a Hamilton microsyringe, immobilization of the animals being avoided during handling. The doses applied were $0.5,1,2 \mathrm{or}$ $5 \mu \mathrm{g}$ dissolved in $0.9 \%$ saline. Control animals received saline alone. Thirty minutes after peptide administration, the rats were decapitated to obtain trunk blood for corticosterone measurement or were subjected to behavioral testing.

\subsection{Plasma corticosterone measurement}

In order to determine plasma corticosterone concentrations, trunk blood was collected in heparinized tubes. The plasma corticosterone concentration was measured by the fluorescence assay described by Zenker and Bernstein [29] as modified by Purves and Sirett [30].

\subsection{Telemetry}

Different doses of KP-13 $(1,2 \mu \mathrm{g})$ or saline alone were injected icv. into conscious rats, between $8: 20$ and $8: 35 \mathrm{a} . \mathrm{m}$. The animals had previously been implanted with an E-mitter (Mini Mitter, USA), which recieves power from the radiofrequency field generated by an energizer-reciever placed below the home cage. The system recorded the motor activity and core temperature every $10 \mathrm{~min}$, the output of which then was processed by the VitalView program provided by the manufacturer.

\subsection{Open field test}

In the open field test novelty-induced locomotor activity was assessed. The rats were removed from their home cages and placed at the center of a white wooden open field box, the floor area of which measured $60 \mathrm{~cm} \times 60 \mathrm{~cm}$, marked into 36 $10 \mathrm{~cm} \times 10 \mathrm{~cm}$ square. The standard source of illumination was a $60 \mathrm{~W}$ bulb at a height of $80 \mathrm{~cm}$. The observed parameters were horizontal locomotion, vertical locomotion, grooming and the number of defecations. The horizontal locomotor activity was characterized by the total number of squares crossed during a 5-min test session (square crossing), the vertical locomotion was determined by the number of rearings (standing on the hind legs), and the grooming activity was established by observing face washing, forepaw licking and head stroking. Every episode of face washing forepaw licking and head stroking was counted as a separate grooming session, independently of how long it actually lasted.

\subsection{Elevated plus maze test}

The elevated plus maze apparatus is a plus-shaped platform elevated $50 \mathrm{~cm}$ above the floor. It consists of two opposing arms $(50 \mathrm{~cm} \times 10 \mathrm{~cm}$ each) with $10 \mathrm{~cm}$ high enclosing walls (closed arms) and two arms with no walls (open arms). A $60 \mathrm{~W}$ light bulb at a height of $80 \mathrm{~cm}$ provided the illumination. The maze was cleane between each session with $96 \%$ ethyl-alcohol and all experiments were conducted between 8:00 a.m. and $10 \mathrm{a} . \mathrm{m}$. Naive rats were placed in the center of the maze facing toward an open arm, and the number of entries per arm and the times spent in the various arms were recorded for a 5 -min period by an observer who was blind to the experimental groups, sitting approximately $1.5 \mathrm{~m}$ away from the apparatus. The test is designed to assess anxiety based on the concept that the open arms are more aversive, and anxious rats therefore spend less time in them [31]. In the figures the ratio of time spent in open arms to total time spent in all arms, the ratio of entries to open arms to total number of entries and the total number of entries into all arms are presented.

\subsection{Statistical analysis}

Data are presented as means \pm SEM. Statistical analysis of the results was performed by analysis of variance (ANOVA). For the corticosterone measurements, open field and elevated plus maze tests, one-way ANOVA was employed, followed by the Holm-Sidak post hoc test for multiple comparisons when the test prerequisites were 


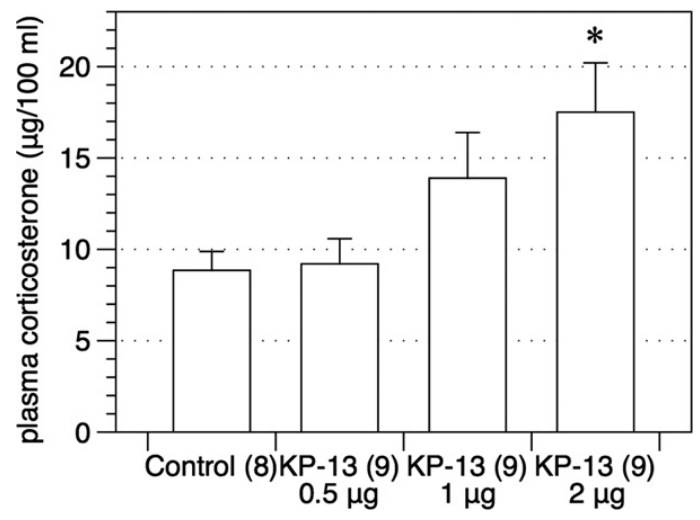

Fig. 1. The effect of KP-13 on the hypothalamus-pituitary-adrenal system. Mean and SEM are expressed. Numbers in parenthesis denote the number of animals used. * $p<0.05$ vs control.

fulfilled. When the test of the homogeneity of variances was not satisfied, nonparametric ANOVA on ranks (Kruskal-Wallis) was performed, followed by Dunn's test for multiple comparisons. For the evaluation of the telemetric recordings, repeated measure ANOVA was performed; only the means were plotted and the pooled standard deviation (PSD) is provided in the figure captions. A probability level of less then 0.05 was accepted as indicating a statistically significant difference.

\section{Results}

\subsection{Effects of KP-13 on corticosterone secretion}

The icv. injection of KP-13 induced a dose-dependent elevation in basal plasma corticosterone level. The corticosterone level following the $2 \mu \mathrm{g}$ dose proved to be statistically different from the control $[F(3,31)=3.955, p<0.02 ;$ Holm-Sidak post hoc test: $p<0.01$ vs control; Fig. 1].

\subsection{Effects of KP-13 on spontaneous locomotion and core temperature}

After the KP-13 treatments between 8:20 and 8:35a.m., increases in both locomotor activity $[F(2,30)=5.842, p<0.01$; Holm-Sidak post hoc test: $p<0.05$ for $1 \mu \mathrm{g}$ and $2 \mu \mathrm{g}$ KP-13 vs control; Fig. 2] and core temperature $[F(2,30)=4.988, p<0.02$; Holm-Sidak post hoc test: $p<0.01$ for $2 \mu \mathrm{g} \mathrm{KP-13}$ vs control; Fig. 3] were observed in the home cages of the animals. In the case of locomotion, this effect was present only for approximately $1 \mathrm{~h}$ after injection and the activity of the rats then returned to the level of the control animals, whereas in the case of the core temperature

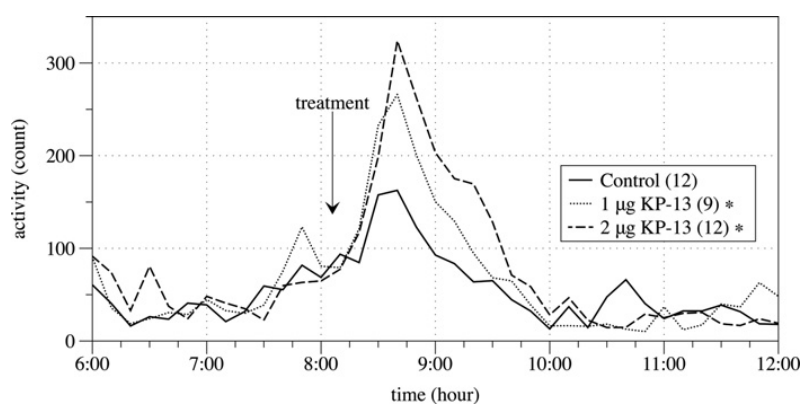

Fig. 2. The effect of KP-13 on the spontaneous motor activity. Data are expressed as means. The pooled standard deviations (PSDs): 62.34 for the control, 69.34 for the $1 \mu \mathrm{g} \mathrm{KP}-13$ treated group, 72.81 for the $2 \mu \mathrm{g} \mathrm{KP}-13$ treated group. Numbers in parenthesis denote the number of animals used. ${ }^{*} p<0.05$ vs control.

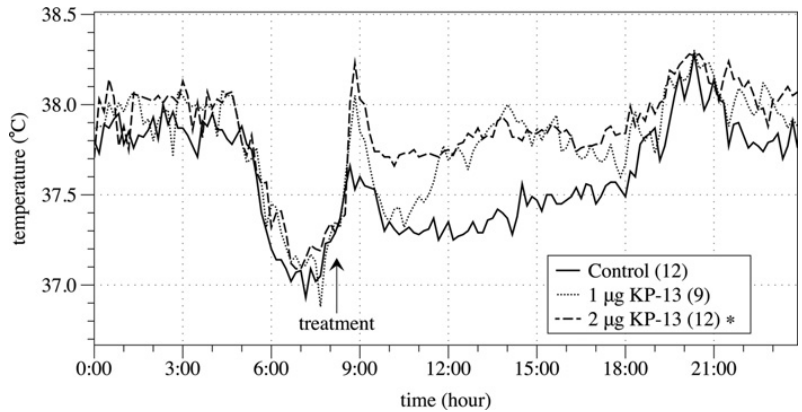

Fig. 3. The effect of $\mathrm{KP}-13$ on the core temperature. Data are expressed as means. The pooled standard deviations (PSDs): 0.40 for the control, 0.49 for the $1 \mu \mathrm{g} \mathrm{KP}-13$ treated group, 0.52 for the $2 \mu \mathrm{g} \mathrm{KP}-13$ treated group. Numbers in parenthesis denote the number of animals used. ${ }^{*} p<0.05$ vs control.

the hyperthermic action of KP-13 persisted for several hours after peptide administration.

\subsection{Effects of KP-13 on open field behavior}

KP-13 evoked a marked increase in the number of square crossings in the open field test $[F(4,41)=3.001, p<0.05$; Holm-Sidak post hoc test: $p<0.01$ vs control; Fig. 4], but did not affect the other recorded parameters: rearing activity $[F(4,41)=0.518, p<0.723]$, grooming $[H=6.079, p=0.193]$ or defecation $[F(4,41)=1.225$, $p=0.315]$ (not shown in figures). The effect of KP-13 administered in a $1 \mu \mathrm{g}$ dose on the number of square crossings proved to be statistically significant.

\subsection{Effects of KP-13 on elevated plus maze behavior}

KP-13 reduced dose-dependently the number of entries into $[F(3,36)=7.095, p<0.001$; Holm-Sidak post hoc test: $p<0.05$ for $1 \mu \mathrm{g}$ and $p<0.001$ for $2 \mu \mathrm{g} \mathrm{KP}-13$ vs control] and the time spent $[F(3,36)=3.298, p<0.05$; Holm-Sidak post hoc test: $p<0.01$ vs control] in the open arms (Fig. 5). A statistically significant change in the time spent in the open arms was caused by the $2 \mu \mathrm{g}$ dose of KP13 , while as concerns the number of entries into open arms, both the 1 and $2 \mu \mathrm{g}$ doses induced significant reductions. There was no difference in the number of total entries between the treatments groups $[F(3,36)=0.555, p=0.648]$.

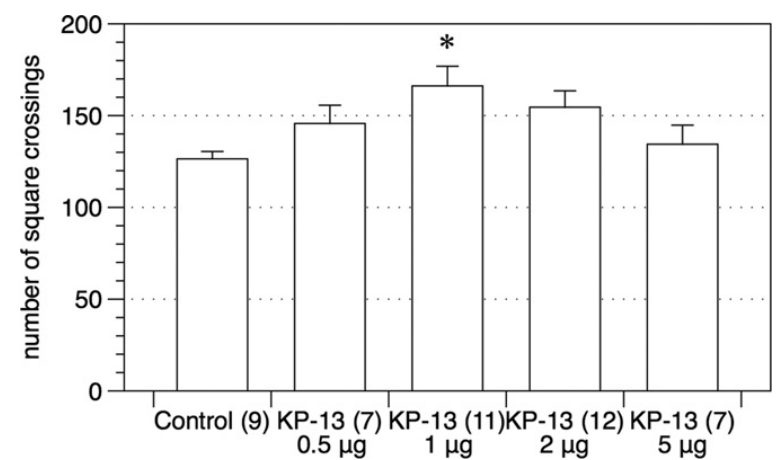

Fig. 4. The effect of KP-13 on exploratory locomotor activity. Mean and SEM are expressed. Numbers in parenthesis denote the number of animals used. ${ }^{*} p<0.05$ vs control. 


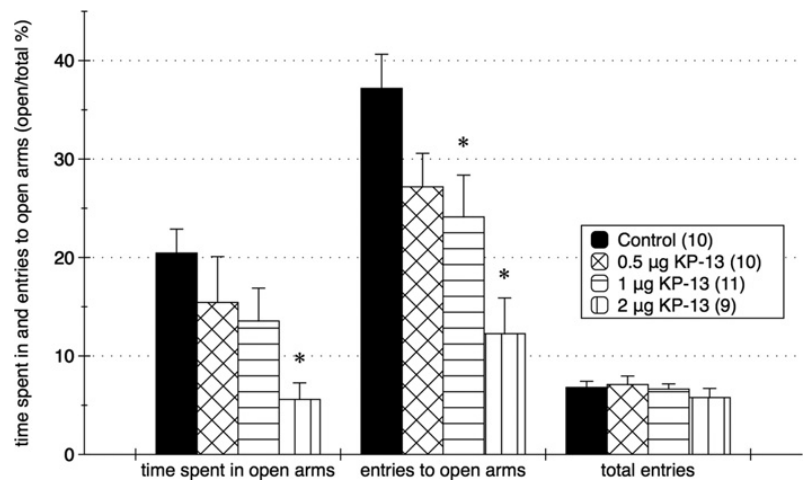

Fig. 5. The effect of KP-13 on elevated plus maze behavior. Mean and SEM are expressed. Numbers in parenthesis denote the number of animals used. ${ }^{*} p<0.05$ vs. control.

\section{Discussion}

In our experiments, KP-13 evoked an elevation of the corticosterone concentration. The most important activators of the HPA axis are corticotropin releasing factor (CRF) and arginine vasopressin (AVP) [32], secreted by the parvocellular part of the PVN. Rao et al [33] recently reported that in PVN-derived cell lines KP-10 generated significant increases in AVP and oxytocin mRNA expression, whereas the CRF mRNA level was affected only at a high dose [33] Thus, a possible explanation for our result is that KP-13 may stimulate the AVP-expressing neurons in the PVN, leading to activation of the HPA axis. Furthermore, a recent study found that kisspeptins can bind to the NPFF2R [15]. Accordingly, in our previous experiments, NPAF, a potent NPFF2R ligand, also stimulated the HPA axis [9]. NPAF was most effective at the dose of $0.5 \mu \mathrm{g}$, whereas it was the $2 \mu \mathrm{g}$ dose of $\mathrm{KP}-13$ that elicited the greatest response. This might be explained by the differences in the affinity and the efficacy of the two peptides. There is also evidence pointing to the direct action of kisspeptin at the level of the pituitary. Kisspeptin has been detected in ovine hypophyseal portal blood [34] and KISS1R has also been found in the pituitary by RT-PCR [14], here co-localized with ACTH expressing cells [35]. However, it must be noted that Rao et al. [33] found that ip. administered KP-10 had no effect on corticosterone secretion in mice. Recent work has also revealed that the activity of KP-10 is strongly dependent on the route of administration in mice: central injection of KP-10 inhibited food intake, whereas ip. administration did not influence it [36]. Additionally, Scott and Brown [37] found KP-10 to be effective in increasing the firing rate of oxytocin neurons on intravenous injection, but not on icv. administration. It is possible that kisspeptin, like the vast majority of neuropeptides, cannot cross the blood-brain barrier or do not reach the neuroendocrine regions relevant to the HPA axis, in sufficient concentration, due to enzymatic degradation [38]. These pharmacokinetic problems can clearly be circumvented by properly designed analogs [38]. Another explanation for the discrepancy between our results and that of Rao et al. [33] might be the use of $\mathrm{KP}-13$ in our experiments instead of KP-10. Lyubimov et al. [15] reported that the NPFF2R binding of kisspeptins depends on the length of the peptide and the presence of the amidated $\mathrm{C}$-terminal dipeptide. KP-13, therefore, proved to be a more potent activator of NPFF2R then KP-10 [15].

Our results demonstrate that kisspeptin can influence the behavior of rats. Open field and telemetric observations revealed that the icv. injection of KP-13 caused a marked activation of novelty-induced and spontaneous locomotion. Increasing doses of KP-13 exhibited a bell-shaped dose-response curve. This type of response is well-known in the literature and has been described in case of other neuropeptides [39,40]. Since KISS1R has been found abundantly in locomotor centers of key importance such as the striatum and amygdala $[10,12,41]$, it is plausible that KP-13 stimulated these regions directly.

Furthermore, KP-13 evoked a preference for the closed arms in the elevated plus maze test, which is indicative of the anxiogenic action of KP-13 in rats. This reinforces our finding that KP-13 activated the HPA axis, as both CRF [42] and AVP [43,44] are potent activators of stress-related behavior. In fact, the central amygdala and the bed nucleus of stria terminalis, both of which have a pivotal role in generating negative emotional responses [45], receive input from kisspeptin neurons [41]

$\mathrm{KP}-13$ induced a significant elevation of core temperature that persisted for several hours. An increased locomotor activity was also observed in these experiments, however, this lasted only an hour suggesting that it is not the cause of the detected changes in temperature. As kisspeptin is a well-known stimulator of $\mathrm{GnRH}$ [2], GnRH might mediate the hyperthermic action of KP-13, which would be in accord with the possible role of GnRH in thermoregulation, suggesting $\mathrm{GnRH}$ as a causative factor in hot flashes $[46,47]$. Other possible explanation could involve the activation of hypothalamic prostaglandin synthesis, increased basal metabolic activity or the stimulation of the hypothalamus-pituitary-thyroid axis.

Our findings are in complete harmony with the growing body of evidence suggesting that kisspeptin may play a more general role in autonomic, neuroendocrine and behavioral regulation. The peptide takes part in cardiovascular [48] and metabolic [49] functions, pregnancy [50] and cognitive processes [51]. Obviously, the control of the aforementioned processes necessitates integration with gonadal activities. The gender-dependent nature of the stress response, stress tolerance and longevity, the interactions between the HPG axis and the HPA system have been well described in the literature [52-56]. Sexual steroids influence the expression of CRF and AVP in the hypothalamus [57,58], whereas chronic stress suppresses the reproductive function $[53,54]$. However, a series of experiments demonstrate that glucocorticoid release from the adrenal gland, actually, preserves the HPG activity during stress $[59,60]$. Taking these phenomena and the versatile physiological functions of kisspeptin into account, it is apparent that, besides the well-characterised PrRP [61-63], further members of the RF-amide family may play integrative roles in the harmonization of the HPG and HPA activity.

Similarly, the dense expression of kisspeptin in the arcuate nucleus and the innervations of the suprachiasmatic nucleus [27] underlines our findings and argues for the role of the peptide in the circadian regulation of metabolic processes, core body temperature and hormone production. Indeed, the basal HPA activity shows a circadian rhythm that is provided by input from the suprachiasmatic nucleus, leading to the pulsatile secretion of CRF $[64,65]$. The role of kisspeptin in circadian control is further supported by recent work establishing the kisspeptin system as an important relay center for the integration of environmental cues and the precise timing of puberty [22], the preovulatory LH surge [19,24], and structural plasticity in seasonal reproduction [26]. Similarly, the observed effect on motor paradigms can also be attributed to a plausible regulatory role in circadian activity and sleep-wake cycle suggested by the expression of kisspeptin neurons in the suprachiasmatic nucleus [27] and the preoptic nucleus of the hypothalamus [66].

In conclusion, our results indicate that centrally injected KP13 activates the HPA axis, induces hyperthermia and stimulates spontaneous and novelty-induced locomotion. Furthermore, KP13 seems to generate anxiety-associated behavior in adult rats. Our data confirm that RF-amide peptides belong to those neuropeptide families that have especially important role in neuroendocrine 
control. Notwithstanding, further investigations are necessary to clarify the mediation and signal transduction of the presented physiological phenomena, with special emphasis on the separation of the unique and overlapping features in the activity profile of the different RF-amides.

\section{Acknowledgements}

This study was supported by grants from ETT (01/2006), RET08-2004, ETT 355-08/2009, TAMOP-4.2.1. and the Neuroscience Research Group of the Hungarian Academy of Sciences.

\section{References}

[1] Fukusumi S, Fujii R, Hinuma S. Recent advances in mammalian RFamide peptides: the discovery and functional analyses of PrRP, RFRPs and QRFP. Peptides 2006;27(5):1073-86.

[2] Kirby HR, Maguire JJ, Colledge WH, Davenport AP, International Union of Basic and Clinical Pharmacology. LXXVII. Kisspeptin receptor nomenclature, distribution, and function. Pharmacological Reviews 2010;62(4):565-78.

[3] Wahab F, Quinton R, Seminara SB. The kisspeptin signaling pathway and its role in human isolated GnRH deficiency. Molecular and Cellular Endocrinology 2011:346(1-2):29-36.

[4] Roa J, Navarro VM, Tena-Sempere M. Kisspeptins in reproductive biology: consensus knowledge and recent developments. Biology of Reproduction 2011;85(4):650-60.

[5] Bonini JA, Jones KA, Adham N, Forray C, Artymyshyn R, Durkin MM, et al. Identification and characterization of two $G$ protein-coupled receptors for neuropeptide FF. Journal of Biological Chemistry 2000;275(50):39324-31.

[6] Matsumoto H, Maruyama M, Noguchi J, Horikoshi Y, Fujiwara K, Kitada C, et al. Stimulation of corticotropin-releasing hormone-mediated adrenocorticotropin secretion by central administration of prolactin-releasing peptide in rats. Neuroscience Letters 2000;285(3):234-8.

[7] Lawrence CB, Ellacott KL, Luckman SM. PRL-releasing peptide reduces food intake and may mediate satiety signaling. Endocrinology 2002:143(2):360-7.

[8] Horiuchi J, Saigusa T, Sugiyama N, Kanba S, Nishida Y, Sato Y, et al. Effects of prolactin-releasing peptide microinjection into the ventrolateral medulla on arterial pressure and sympathetic activity in rats. Brain Research 2002;958(1):201-9.

[9] Jaszberenyi M, Bagosi Z, Thurzo B, Foldesi I, Szabo G, Telegdy G. Endocrine, behavioral and autonomic effects of neuropeptide AF. Hormones and Behavior 2009;56(1):24-34.

[10] Kotani M, Detheux M, Vandenbogaerde A, Communi D, Vanderwinden JM, Le Poul E, et al. The metastasis suppressor gene KiSS-1 encodes kisspeptins, the natural ligands of the orphan G protein-coupled receptor GPR54. Journal of Biological Chemistry 2001;276(37):34631-6.

[11] Ohtaki T, Shintani Y, Honda S, Matsumoto H, Hori A, Kanehashi K, et al. Metastasis suppressor gene KiSS-1 encodes peptide ligand of a G-protein-coupled receptor. Nature 2001;411(6837):613-7.

[12] Muir AI, Chamberlain L, Elshourbagy NA, Michalovich D, Moore DJ, Calamari A, et al. AXOR12, a novel human $G$ protein-coupled receptor, activated by the peptide KiSS-1. Journal of Biological Chemistry 2001;276(31):28969-75.

[13] Brailoiu GC, Dun SL, Ohsawa M, Yin D, Yang J, Chang JK, et al. KiSS-1 expression and metastin-like immunoreactivity in the rat brain. The Journal of Comparative Neurology 2005;481(3):314-29.

[14] Richard N, Corvaisier S, Camacho E, Kottler ML. KiSS-1 and GPR54 at the pituitary level: overview and recent insights. Peptides 2009;30(1):123-9.

[15] Lyubimov Y, Engstrom M, Wurster S, Savola JM, Korpi ER, Panula P. Human kisspeptins activate neuropeptide FF2 receptor. Neuroscience 2010;170(1):117-22.

[16] Panula P, Kalso E, Nieminen M, Kontinen VK, Brandt A, Pertovaara A. Neuropeptide FF and modulation of pain. Brain Research 1999;848(1-2):191-6.

[17] Lee JH, Welch DR. Suppression of metastasis in human breast carcinoma MDAMB-435 cells after transfection with the metastasis suppressor gene, KiSS-1. Cancer Research 1997;57(12):2384-7.

[18] Papaoiconomou E, Msaouel P, Makri A, Diamanti-Kandarakis E, Koutsilieris M. The role of kisspeptin/GPR54 in the reproductive system. In Vivo 2011;25(3):343-54.

[19] Khan AR, Kauffman AS. The role of kisspeptin and RFamide-related peptide3 neurones in the circadian-timed preovulatory luteinising hormone surge. Journal of Neuroendocrinology 2012;24(1):131-43.

[20] de Roux N, Genin E, Carel JC, Matsuda F, Chaussain JL, Milgrom E. Hypogonadotropic hypogonadism due to loss of function of the KiSS1-derived peptide receptor GPR54. Proceedings of the National Academy of Sciences of the United States of America 2003;100(19):10972-6.

[21] Seminara SB, Messager S, Chatzidaki EE, Thresher RR, Acierno JSJ, Shagoury JK, et al. The GPR54 gene as a regulator of puberty. New England Journal of Medicine 2003;349(17):1614-27.

[22] Navarro VM, Fernández-Fernández R, Castellano JM, Roa J, Mayen A, Barreiro $\mathrm{ML}$, et al. Advanced vaginal opening and precocious activation of the reproductive axis by KiSS-1 peptide, the endogenous ligand of GPR54. The Journal of Physiology 2004;561(2):379-86.
[23] Maeda K, Ohkura S, Uenoyama Y, Wakabayashi Y, Oka Y, Tsukamura $\mathrm{H}$, et al. Neurobiological mechanisms underlying GnRH pulse generation by the hypothalamus. Brain Research 2010;1364: 103-15.

[24] Smarr BL, Morris E, de la Iglesia HO. The dorsomedial suprachiasmatic nucleus times circadian expression of Kiss1 and the luteinizing hormone surge. Endocrinology 2012;153(6):2839-50.

[25] Castano JP, Martinez-Fuentes AJ, Gutierrez-Pascual E, Vaudry H, Tena-Sempere M, Malagon MM. Intracellular signaling pathways activated by kisspeptins M, Magagon MM. Intracellular signaling pathways activated by kisspeptins
through GPR54: do multiple signals underlie function diversity? Peptides through GPR54:

[26] Lehman MN, Ladha Z, Coolen LM, Hileman SM, Connors JM, Goodman RL. Neuronal plasticity and seasonal reproduction in sheep. European Journal of Neuroscience 2010;32(12):2152-64.

[27] Clarkson J, d'Anglemont de Tassigny X, Colledge WH, Caraty A, Herbison AE. Distribution of kisspeptin neurones in the adult female mouse brain. Journal of Neuroendocrinology 2009;21(8):673-82.

[28] Pellegrino LJ, Pellegrino AS, Cushman AJ. A stereotaxic atlas of the rat brain. New York: Plenum; 1979. p. 122

29] Zenker N, Bernstein DE. The estimation of small amounts of corticosterone in rat plasma. The Journal of Biological Chemistry 1958;231(2):695.

30] Purves HD, Sirett NE. Assay of corticotrophin in dexamethasone-treated rats. Endocrinology 1965;77(2):366

31] Walf AA, Frye CA. The use of the elevated plus maze as an assay of anxietyrelated behavior in rodents. Nature Protocols 2007;2(2):322-8.

[32] Rivier C, Vale W. Interaction of corticotropin-releasing factor and arginine vasopressin on adrenocorticotropin secretion in vivo. Endocrinology 1983;113(3):939.

[33] Rao YS, Mott NN, Pak TR. Effects of kiss peptin on parameters of the HPA axis. Endocrine 2011:1-9.

[34] Smith JT, Rao A, Pereira A Caraty A, Millar RP, Clarke IJ. Kisspeptin is present in ovine hypophysial portal blood but does not increase during the preovulatory luteinizing hormone surge: evidence that gonadotropes are not direct targets of kisspeptin in vivo. Endocrinology 2008;149(4):1951.

[35] Ramaswamy S, Gibbs RB, Plant TM. Studies of the localisation of kisspeptin within the pituitary of the rhesus monkey (Macaca mulatta) and the effect of kisspeptin on the release of non-gonadotropic pituitary hormones. Journal of Neuroendocrinology 2009;21(10):795-804.

[36] Stengel A, Wang L, Goebel-Stengel M, Tache Y. Centrally injected kisspeptin reduces food intake by increasing meal intervals in mice. Neuroreport 2011;22(5):253-7.

[37] Scott V, Brown CH. Kisspeptin activation of supraoptic nucleus neurons in vivo. Endocrinology 2011;152(10):3862-70.

[38] Pineda R, Garcia-Galiano D, Roseweir A, Romero M, Sanchez-Garrido MA, Ruiz-Pino F, et al. Critical roles of kisspeptins in female puberty and preovulatory gonadotropin surges as revealed by a novel antagonist. Endocrinology 2010;151(2):722-30.

[39] Morio H, Tatsuno I, Hirai A, Tamura Y, Saito Y. Pituitary adenylate cyclaseactivating polypeptide protects rat-cultured cortical neurons from glutamateinduced cytotoxicity. Brain Research 1996;741(1-2):82-8.

[40] Bujdoso E, Jaszberenyi M, Tomboly C, Toth G, Telegdy G. Effects of endomorphin-1 on open-field behavior and on the hypothalamic-pituitaryadrenal system. Endocrine 2001;14(2):221-4.

[41] Lee DK, Nguyen T, O'Neill GP, Cheng R, Liu Y, Howard AD, et al. Discovery of a receptor related to the galanin receptors. FEBS Letters 1999:446(1):103-7.

[42] Koob GF, Thatcher-Britton K. Stimulant and anxiogenic effects of corticotropin releasing factor. Progress in Clinical and Biological Research 1985;192:499-506.

[43] Ferris CF, Albers HE, Wesolowski SM, Goldman BD, Luman SE. Vasopressin injected into the hypothalamus triggers a stereotypic behavior in golden hamsters. Science 1984;224(4648):521.

[44] Bielsky IF, Hu SB, Szegda KL, Westphal H, Young LJ. Profound impairment in social recognition and reduction in anxiety-like behavior in vasopressin V1a receptor knockout mice. Neuropsychopharmacology 2004:29(3):483-93.

[45] Davis M, Walker DL, Miles L, Grillon C. Phasic vs sustained fear in rats and humans: role of the extended amygdala in fear vs anxiety. Neuropsychopharmacology 2010;35(1):105-35

[46] Lomax P, Bajorek JG, Chesarek W, Tataryn IV. Thermoregulatory effects of luteinizing hormone releasing hormone in the rat. In: Thermoregulatory mechanisms and their therapeutic implications. Basel: Karger; 1980. pp. 208-211.

[47] de Boer H, van Gastel P, van Sorge A. Luteinizing hormone-releasing hormone and postmenopausal flushing. New England Journal of Medicine 2009;361(12):1218-9.

[48] Mead EJ, Maguire JJ, Kuc RE, Davenport AP. Kisspeptins are novel potent vasoconstrictors in humans, with a discrete localization of their receptor, G protein-coupled receptor 54, to atherosclerosis-prone vessels. Endocrinology 2007; 148(1):140.

[49] Bowe JE, King AJ, Kinsey-Jones JS, Foot VL, Li XF, O‘Byrne KT, Persaud SJ, Jones PM. Kisspeptin stimulation of insulin secretion: mechanisms of action in mouse islets and rats. Diabetologia 2009;52(5):855-62.

[50] Bilban M, Ghaffari-Tabrizi N, Hintermann E, Bauer S, Molzer S, Zoratti C, Malli R, Sharabi A, Hiden U, Graier W, et al. Kisspeptin-10, a KiSS-1/metastinderived decapeptide, is a physiological invasion inhibitor of primary human trophoblasts. Journal of Cell Science 2004;117(Pt 8):1319-28.

[51] Arai AC, Orwig N. Factors that regulate KiSS1 gene expression in the hippocampus. Brain Research 2008;1243:10-8. 
[52] Kudielka BM, Buske-Kirschbaum A, Hellhammer DH, Kirschbaum C. HPA axis responses to laboratory psychosocial stress in healthy elderly adults, younger adults, and children: impact of age and gender. Psychoneuroendocrinology 2004;29(1):83-98.

[53] Chandran UR, Attardi B, Friedman R, Dong KW, Roberts JL, DeFranco DB. Glucocorticoid receptor-mediated repression of gonadotropin-releasing hormone promoter activity in GT1 hypothalamic cell lines. Endocrinology 1994;134(3):1467.

[54] Li XF, Knox AM, O'Byrne KT. Corticotrophin-releasing factor and stress-induced inhibition of the gonadotrophin-releasing hormone pulse generator in the inhibition of the gonadotrophin-releasing

[55] Viau V, Meaney MJ. Testosterone-dependent variations in plasma and intrapituitary corticosteroid binding globulin and stress hypothalamic-pituitaryadrenal activity in the male rat. Journal of Endocrinology 2004;181(2):223.

[56] Weiser MJ, Handa RJ. Estrogen impairs glucocorticoid dependent negative feedback on the hypothalamic-pituitary-adrenal axis via estrogen receptor alpha within the hypothalamus. Neuroscience 2009;159(2):883-95.

[57] Roy BN, Reid RL, Van Vugt DA. The effects of estrogen and progesterone on corticotropin-releasing hormone and arginine vasopressin messenger ribonucleic acid levels in the paraventricular nucleus and supraoptic nucleus of the rhesus monkey. Endocrinology 1999;140(5):2191.

[58] Viau V, Lee P, Sampson J, Wu J. A testicular influence on restraint-induced activation of medial parvocellular neurons in the paraventricular nucleus in the male rat. Endocrinology 2003;144(7):3067.

[59] Matsuwaki T, Suzuki M, Yamanouchi K, Nishihara M. Glucocorticoid counteracts the suppressive effect of tumor necrosis factor-alpha on the surge of luteinizing hormone secretion in rats. Journal of Endocrinology 2004;181(3):509-13.

[60] Matsuwaki T, Kayasuga Y, Yamanouchi K, Nishihara M. Maintenance of gonadotropin secretion by glucocorticoids under stress conditions through the inhibition of prostaglandin synthesis in the brain. Endocrinology 2006;147(3):1087-93.

[61] Takayanagi Y, Onaka T. Roles of prolactin-releasing peptide and RFamide related peptides in the control of stress and food intake. FEBS Journal 2010;277(24):4998-5005.

[62] Onaka T, Takayanagi Y, Leng G. Metabolic and stress-related roles of prolactin-releasing peptide. Trends in Endocrinology and Metabolism 2010;21(5):287-93

[63] Lin SH. Prolactin-releasing peptide. Results and Problems in Cell Differentiation 2008;46:57-88

[64] Moore RY, Eichler VB. Loss of a circadian adrenal corticosterone rhythm following suprachiasmatic lesions in the rat. Brain Research 1972;42(1): 201-6.

[65] Vrang N, Larsen PJ, Mikkelsen JD. Direct projection from the suprachiasmatic nucleus to hypophysiotrophic corticotropin-releasing factor immunoreactive cells in the paraventricular nucleus of the hypothalamus demonstrated by means of Phaseolus vulgaris-leucoagglutinin tract tracing. Brain Research 1995;684(1):61-9.

[66] Clarkson J, Herbison AE. Postnatal development of kisspeptin neurons in mouse hypothalamus; sexual dimorphism and projections to gonadotropin-releasing hormone neurons. Endocrinology 2006;147(12):5817-25. 


\title{
Neurotransmissions of antidepressant-like effects of kisspeptin-13
}

\author{
M. Tanaka ${ }^{a}$, K. Csabafi ${ }^{b}$, G. Telegdy a,b,* \\ ${ }^{a}$ Neuroscience Research Group of the Hungarian Academy of Science, University of Szeged, Szeged, Hungary
}

b Department of Pathophysiology, Faculty of Medicine, University of Szeged, Szeged, Hungary

\section{A R T I C L E I N F O}

\section{Article history:}

Received 21 April 2012

Received in revised form 10 July 2012

Accepted 29 August 2012

Available online 18 September 2012

\section{Keywords:}

Kisspeptins

Kisspeptin-13

Receptors

Depression

\begin{abstract}
A B S T R A C T
Kisspeptins are G protein-coupled receptor ligands originally identified as human metastasis suppressor gene products that have the ability to suppress melanoma and breast cancer metastasis and which have recently been found to play an important role in initiating the secretion of gonadotropin-releasing hormone at puberty. In the brain, the gene is transcribed within the hippocampal dentate gyrus. Kisspeptin-13, one of the endogenous isoforms, consists of 13 amino acids. In this work, antidepressant-like effects of kisspeptin-13 were studied and the potential involvement of the adrenergic, serotonergic, cholinergic, dopaminergic and gabaergic receptors in its antidepressant-like effects was investigated in a modified forced swimming test (FST) in mice. The mice were pretreated with a nonselective $\alpha$-adrenergic receptor antagonist, phenoxybenzamine, an $\alpha_{1} / \alpha_{2 \beta}$-adrenergic receptor antagonist, prazosin, an $\alpha_{2}$-adrenergic receptor antagonist, yohimbine, a $\beta$-adrenergic receptor antagonist, propranolol, a mixed $5-\mathrm{HT}_{1} / 5-\mathrm{HT}_{2}$ serotonergic receptor antagonist, methysergide, a nonselective $5-\mathrm{HT}_{2}$ serotonergic receptor antagonist, cyproheptadine, a nonselective muscarinic acetylcholine receptor antagonist, atropine, a $\mathrm{D}_{2}, \mathrm{D}_{3}, \mathrm{D}_{4}$ dopamine receptor antagonist, haloperidol, or a $\gamma$-aminobutyric acid subunit $\mathrm{A}$ receptor antagonist, bicuculline.

The FST revealed that kisspeptin-13 reversed the immobility, climbing and swimming times, suggesting antidepressant-like effects. Phenoxybenzamine, yohimbine and cyproheptadine prevented the effects of kisspeptin-13 on the immobility, climbing and swimming times, whereas prazosin, propranolol, methysergide, atropine, haloperidol and bicuculline did not modify the effects of kisspeptin-13.

The results demonstrated that the antidepressant-like effects of kisspeptin-13 in a modified mouse FST are mediated, at least in part, by an interaction of the $\alpha_{2}$-adrenergic and $5-\mathrm{HT}_{2}$ serotonergic receptors.
\end{abstract}

(c) 2012 Elsevier B.V. All rights reserved.

\section{Introduction}

Kisspeptin (KP), formerly known as metastin, was originally identified as a human metastasis suppressor that inhibits the metastasis of melanoma and breast cancer [1]. This $\mathrm{G}$ protein-coupled receptor ligand was recently found to play an important role in the maturation and function of reproductive axis, including the sexual differentiation of the brain, the timing of puberty, the regulation of gonadotropin-releasing hormone $(\mathrm{GnRH})$ at puberty, and the control of fertility by metabolic and environmental cues [2]. In the central nervous system, KP is transcribed within the hippocampal dentate gyrus. KP-13, one of the endogenous isoforms, consists of 13 amino acids [3]. Little is known concerning the mechanisms and pathways of the action of KP-13 on the brain functions.

In the present investigation, antidepressant-like effects of KP-13 were studied and the potential involvement of the adrenergic, serotonergic, cholinergic, dopaminergic and gabaergic receptors in its antidepressantlike effects was investigated in a modified forced swimming test (FST) in mice. Mice were pretreated with a non-selective $\alpha$-adrenergic

\footnotetext{
* Corresponding author at: Semmelweis 1, Szeged, Hungary. Tel.: + 3662 545797; fax: +3662545710 .

E-mail address: telegdy@patph.szote.u-szeged.hu (G. Telegdy).
}

receptor antagonist, phenoxybenzamine, an $\alpha_{1} / \alpha_{2 \beta}$-adrenergic receptor antagonist, prazosin, an $\alpha_{2}$-adrenergic receptor antagonist, yohimbine, a $\beta$-adrenergic receptor antagonist, propranolol, a mixed 5- $\mathrm{HT}_{1} /$ $5-\mathrm{HT}_{2}$ serotonergic receptor antagonist, methysergide, a nonselective $5-\mathrm{HT}_{2}$ serotonergic receptor antagonist, cyproheptadine, a nonselective muscarinic acetylcholine receptor antagonist, atropine, a $\mathrm{D}_{2}, \mathrm{D}_{3}, \mathrm{D}_{4}$ dopamine receptor antagonist, haloperidol, or a $\gamma$-aminobutyric acid subunit $\mathrm{A}\left(\mathrm{GABA}_{\mathrm{A}}\right)$ receptor antagonist, bicuculline.

\section{Materials and methods}

\subsection{Animals}

$\mathrm{CD}_{1}$ (Charles Dawley) male mice were kept and handled during the experiments in accordance with the instructions of the University of Szeged Ethical Committee for the Protection of Animals in Research. Each animal was used in the experiments only once. The animals were six week old, weighed between 28 and $35 \mathrm{~g}$. They were housed in cages in a room maintained at constant temperature $\left(25 \pm 1^{\circ} \mathrm{C}\right)$ and on a 12-h dark-light cycle (lights on at 06:00-18:00 h) with free access to tap water and standard laboratory food. At least 1 week of recovery from surgery was allowed before the experiments. 


\subsection{Surgery}

The mice were implanted with a cannula introduced into the right lateral brain ventricle in order to allow intracerebroventricular (i.c.v.) administration. The polystyrene cannula was inserted stereotaxically into the ventricle at the coordinates $0.2 \mathrm{~mm}$ posterior, $0.2 \mathrm{~mm}$ lateral to the bregma, and $2.0 \mathrm{~mm}$ deep from the dural surface [4]. The cannula was secured with cyanoacrylate (Ferrobond) (Budapest, Hungary). The mice were allowed a minimum of 5 days to recover from surgery before any i.c.v. administration.

\subsection{Materials}

KP-13 was from Bachem (Basel, Switzerland); phenoxybenzamine hydrochloride from Smith Kline \& French (Herts, UK); prazosin hydrochloride and yohimbine hydrochloride from Tocris (Cologne, Germany); propranolol hydrochloride from ICI Ltd. (Macclesfield, UK); methysergide hydrogenmaleate from Sandoz (Cologne, Germany); cyproheptadine hydrochloride from Tocris (Bristol, UK); atropine sulfate from EGYS (Budapest, Hungary); haloperidol from G. Richter (Budapest, Hungary); and bicuculline methiodide from Sandoz (Basel, Switzerland).

KP-13 was lyophilized in a quantity of $10 \mu \mathrm{g}$ per ampoule and stored at $-20{ }^{\circ} \mathrm{C}$. Immediately before the experiments, the $\mathrm{KP}-13$ was dissolved in sterile pyrogen-free $0.9 \%$ saline and administered i.c.v. via the cannula in a volume of $2 \mu$.

\subsection{Forced swimming test}

The modified mouse FST was conducted as reported previously [5,6]. The mice were forced to swim individually in a glass cylinder $12 \mathrm{~cm}$ in diameter and $30 \mathrm{~cm}$ in height, filled with water to a height of $20 \mathrm{~cm}$. The temperature of the water was adjusted to $25 \pm 1{ }^{\circ} \mathrm{C}$. The water was changed between the individual mice. A 15 -min pretest session was followed $24 \mathrm{~h}$ later by a 5 -min test session. Phenoxybenzamine (2 mg/kg, i.p.) $(N=20)$, prazosin $(62.5 \mu \mathrm{g} / \mathrm{kg}$, i.p. $)(N=40)$, yohimbine ( $5 \mathrm{mg} / \mathrm{kg}$, i.p.) $(N=40)$, propranolol $(5 \mathrm{mg} / \mathrm{kg}$, i.p. $)(N=40)$, methysergide $(5 \mathrm{mg} / \mathrm{kg}$, i.p.) $(N=40)$, cyproheptadine ( $3 \mathrm{mg} / \mathrm{kg}$, i.p.) $(N=59)$, atropine $(2 \mathrm{mg} / \mathrm{kg}$, i.p. $)(N=10)$, haloperidol $(10 \mu \mathrm{g} / \mathrm{kg}$, i.p. $)(N=40)$ or bicuculline ( $2 \mathrm{mg} / \mathrm{kg}$, i.p.) $(N=40)$ was administered $1 \mathrm{~h}$ before the test session, followed 30 min later by KP-13 (2.0 $\mu \mathrm{g} / 2 \mu \mathrm{l}$, i.c.v.) [7-12]. Physiological saline was used as vehicle control. A time-sampling technique was applied to score the durations of climbing, swimming and immobility. Climbing time was measured when the mouse was participating in active vertical motion with its forelegs above the water level; swimming time was recorded when the mouse was moving horizontally on the surface of the water; and immobility time was registered when the mouse was in a upright position on the surface with its front paws together and making only those movements necessary to keep itself afloat.

\subsection{Statistical analysis}

The analysis of variance (two-way ANOVA) test was followed by Tukey's test for multiple comparisons with unequal cell size. Probability values $(P)$ of less than 0.05 were regarded as indicative of significant differences.

\section{Results}

Relative to the vehicle control, KP-13 (2.0 $\mu \mathrm{g} / 2 \mu \mathrm{l})$-administered mice exhibited a significantly decreased immobility time $[F(3.35)=14.98$ : $P<0.05]$, a significantly increased climbing time $[F(3.35)=7.75$ : $P<0.05]$ and a significantly increased swimming time $[F(3.35)=11.10$ : $P<0.05$ ] (Fig. 1).

Phenoxybenzamine per se ( $2 \mathrm{mg} / \mathrm{kg}$, i.p.) did not affect the immobility time, climbing time or swimming time. In KP-13-treated mice, pretreatment with phenoxybenzamine partially reversed the KP-13induced change in the immobility time, and decreased the changes in the climbing and swimming times (Fig. 2).

Prazosin per se $(62.5 \mu \mathrm{g} / \mathrm{kg}$, i.p.) did not affect the immobility time, the climbing time or the swimming time. In the KP-13-treated mice, pretreatment with prazosin did not reverse the KP-13-induced changes in the immobility time, the climbing time or the swimming time (data not shown).

Yohimbine per se $(5 \mathrm{mg} / \mathrm{kg}$, i.p.) did not affect the immobility time, the climbing time or the swimming time. In KP-13-treated mice, pretreatment with yohimbine partially reversed the immobility time, the climbing time and the swimming time (Fig. 3).

Methysergide per se $(5 \mathrm{mg} / \mathrm{kg}$, i.p.) did not affect the immobility time, the climbing time or the swimming time. In the KP-13-treated mice, pretreatment with methysergide did not reverse the immobility time, the climbing time or the swimming time (data not shown).

Cyproheptadine per se ( $3 \mathrm{mg} / \mathrm{kg}$, i.p.) did not affect the immobility time, the climbing time or the swimming time. In the KP-13-treated mice, pretreatment with cyproheptadine resulted in an increased immobility time and decreased the changes in the climbing and swimming times (Fig. 4).

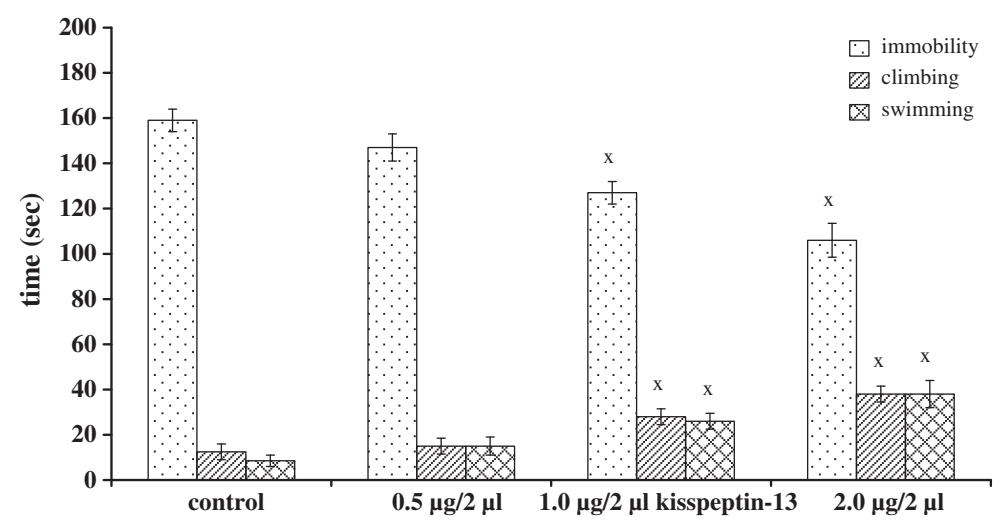

Fig. 1. The antidepressant-like effects of kisspeptin-13 in modified mouse forced swim test (FST). Control ( $N=12$ ), kisspeptin-13 $0.5 \mu \mathrm{g} / 2 \mu \mathrm{l}$, i.c.v. ( $N=6$ ), kisspeptin-13 1.0 $\mu \mathrm{g} / 2 \mu \mathrm{l}$, i.c.v. $(N=12)$, kisspeptin-13 $2.0 \mu \mathrm{g} / 2 \mu \mathrm{l}$, i.c.v. $(N=5)$. x: $P<0.05 v$ s. control ( $N$ : the number of animals, $P$ : probability). 


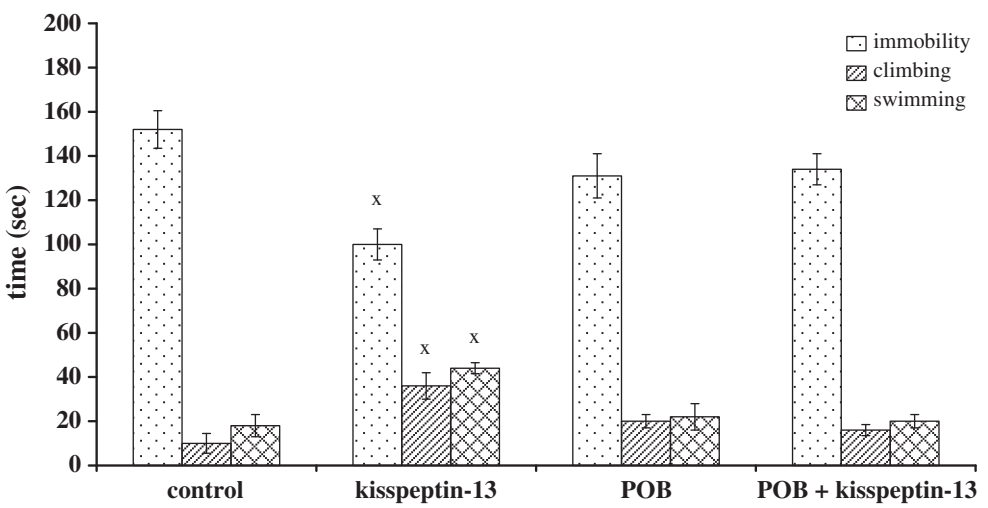

Fig. 2. The effect of a nonselective $\alpha$-adrenergic receptor antagonist, phenoxybenzamine (POB) in kisspeptin-13-induced antidepressant-like action in modified mouse forced swim test (FST). Control $(N=5)$, kisspeptin-13 $2.0 \mu \mathrm{g} / 2 \mu \mathrm{l}$, i.c.v. $(N=5)$, phenoxybenzamine (POB) $2.0 \mathrm{mg} / \mathrm{kg}$, i.p. $(N=5)$, phenoxybenzamine (POB) $2.0 \mathrm{mg} / \mathrm{kg}$, i.p. $+\mathrm{kisspeptin-13}$ $2.0 \mu \mathrm{g} / 2 \mu \mathrm{l}$, i.c.v. $(N=5)$. x: $P<0.05$ vs. control (N: the number of animals, $P$ : probability).

Propranolol per se $(5 \mathrm{mg} / \mathrm{kg}$, i.p.) did not affect the immobility time, the climbing time or the swimming time. In the KP-13-treated mice, pretreatment with propranolol did not lead to an increase in the immobility time, and did not affect the climbing time or the swimming time (data not shown).

Atropine per se ( $2 \mathrm{mg} / \mathrm{kg}$, i.p.) did not affect the immobility time, the climbing time or the swimming time. In the KP-13-treated mice, pretreatment with atropine did not affect the increased immobility time or the decreased climbing and swimming times (data not shown).

Haloperidol per se $(10 \mu \mathrm{g} / \mathrm{kg}$, i.p.) did not affect the immobility time, the climbing time or the swimming time. In the KP-13-treated mice, pretreatment with haloperidol did not increase the immobility time, nor affect the climbing or swimming times (data not shown).

Bicuculline per se $(2 \mathrm{mg} / \mathrm{kg}$, i.p.) did not affect the immobility time, the climbing time or the swimming time. In the KP-13-treated mice, pretreatment with bicuculline did not increase the immobility time, the climbing time or the swimming time (data not shown).

The above results reveal that the antidepressant-like effects of $\mathrm{KP}-13$ in this modified mouse FST are mediated, at least in part, by $\alpha_{2}$-adrenergic receptors and 5 - $\mathrm{HT}_{2}$ serotonergic receptors.

\section{Discussion}

In the central nervous system KP-expressing neurons are located in the anteroventral periventricular nucleus (AVPV), the periventricular nucleus (PVN), the anterodorsal preoptic nucleus and the arcuate nucleus (Arc) [13]. In close relationship with the PVN, the neurons of the AVPV and Arc project fibers into the preoptic area rich in GnRH cell bodies. It is now known that KP stimulates the secretion of $\mathrm{GnRH}$, which is sensitive to steroid levels [14]. Previous studies have shown that the luteinizing hormone-releasing hormone antagonist cetrorelix and the growth hormone releasing-hormone antagonist MZ-4-71 exert antidepressant-like effects in a modified mice FST, suggesting close relationships between growth hormone regulation and the alleviation of mood disorders [15-18].

In the present study, KP-13 proved to display antidepressant-like effects in a modified FST.

To clarify the mechanisms of the antidepressant-like actions of KP-13, various receptor blockers were applied before KP-13 administration. The receptor blocker doses were selected so that the blockers per se were ineffective, but were able to block the action of a neuropeptide as described in a previous study [19]. The observation made with the receptor blockers indicated that the action of KP-13 is mediated by certain receptors.

The nonselective $\alpha$-adrenergic receptor antagonist phenoxybenzamine, the $\alpha_{2}$-adrenergic receptor antagonist yohimbine and the nonselective $5-\mathrm{HT}_{2}$ serotonergic receptor antagonist cyproheptadine prevented the effects of KP-13 on the immobility, climbing and swimming times. The $\alpha_{1} / \alpha_{2 \beta}$-adrenergic receptor antagonist prazosin, the $\beta$-adrenergic receptor antagonist propranolol, the mixed $5-\mathrm{HT}_{1} / 5-\mathrm{HT}_{2}$ serotonergic receptor antagonist methysergide, the nonselective muscarinic acetylcholine receptor antagonist atropine,

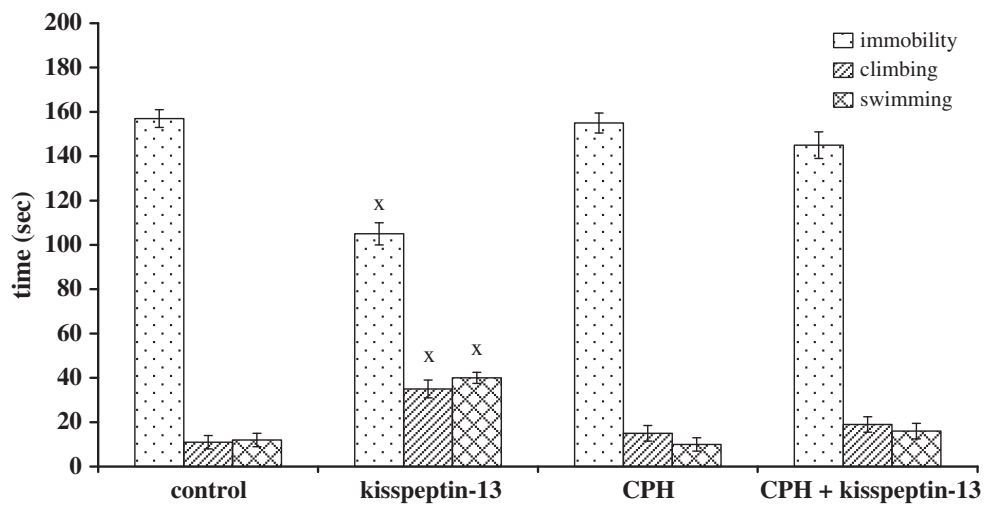

Fig. 3. The effect of a nonselective $\alpha$-adrenergic receptor antagonist, yohimbine (YOH) in kisspeptin-13-induced antidepressant-like action in modified mouse forced swim test (FST). Control $(N=10)$, kisspeptin-13 $2.0 \mu \mathrm{g} / 2 \mu \mathrm{l}$, i.c.v. $(N=10)$, yohimbine $(\mathrm{YOH}) 5.0 \mathrm{mg} / \mathrm{kg}$, i.p. $(N=10)$, yohimbine $(\mathrm{YOH}) 5.0 \mathrm{mg} / \mathrm{kg}$, i.p. $+\mathrm{kisspeptin}-132.0 \mu \mathrm{g} / 2 \mu \mathrm{l}$, i.c.v. $(N=10)$. x: $P<0.05$ vs. control ( $N$ : the number of animals, $P$ : probability). 


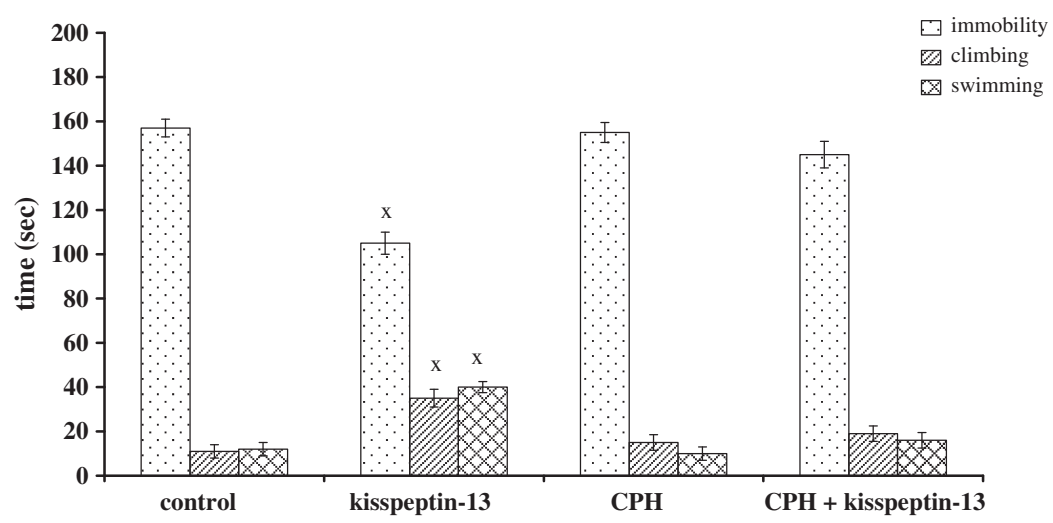

Fig. 4. The effect of a nonselective $5-\mathrm{HT}_{2}$ serotonergic receptor antagonist, cyproheptadine ( $\left.\mathrm{CPH}\right)$ in kisspeptin-13-induced antidepressant-like action in modified mouse forced swim test (FST). Control $(N=14)$, kisspeptin-13 $2.0 \mu \mathrm{g} / 2 \mu \mathrm{l}$, i.c.v. $(N=15)$, cyproheptadine (CPH) $3.0 \mathrm{mg} / \mathrm{kg}$, i.p. $(N=15)$, cyproheptadine (CPH) $3.0 \mathrm{mg} / \mathrm{kg}$, i.p. + kisspeptin-13 $2.0 \mu \mathrm{g} / 2 \mu \mathrm{l}$, i.c.v. $(N=15)$. x: $P<0.05$ vs. control (N: the number of animals, $P$ : probability).

the $\mathrm{D}_{2}, \mathrm{D}_{3}, \mathrm{D}_{4}$ dopamine receptor antagonist haloperidol and the $G A B A_{A}$ receptor antagonist bicuculline did not modify the effects of KP-13.

The results demonstrated that the antidepressant-like effects of $\mathrm{KP}-13$ in this modified mouse FST are mediated, at least in part, by an interaction of the $\alpha_{2}$-adrenergic and 5- $\mathrm{HT}_{2}$ serotonergic receptors.

\section{Acknowledgments}

This work was supported by grants from ETT (008/2003) and RET (08/2004).

\section{References}

[1] Harms JF, Welch DR, Miele ME. KISS1 metastasis suppression and emergent pathways. Clin Exp Metastasis 2003;20(1):11-8.

[2] Pineda R, Aguilar E, Pinilla L, Tena-Sempere M. Physiological roles of the kisspeptin/ GPR54 system in the neuroendocrine control of reproduction. Prog Brain Res 2010; $181: 55-77$

[3] Tsutsui K, Bentley GE, Kriegsfeld LJ, Osugi T, Seong JY, Vaudry H. Discovery and evolutionary history of gonadotrophin-inhibitory hormone and kisspeptin: new key neuropeptides controlling reproduction. J Neuroendocrinol 2010;22(7): 716-27.

[4] Pellergrino AS, Cushman AJ. Stereotaxic atlas of the rat brain. New York: Plenum Press; 1979. pp. 8-57.

[5] Detke MJ, Rickels M, Lucki I. Active behaviors in the rat forced swimming test differentially produced by serotonergic and noradrenergic antidepressants. Psychopharmacology (Berl) 1995;121(1):66-72.

[6] Khisti RT, Chopde CT, Jain SP. Antidepressant-like effect of the neurosteroid 3alpha-hydroxy-5alpha-pregnan-20-one in mice forced swim test. Pharmacol Biochem Behav 2000;67(1):137-43
[7] Consoli D, Leggio GM, Mazzola C, Micale V, Drago F. Behavioral effects of the beta3 adrenoceptor agonist SR58611A: is it the putative prototype of a new class of antidepressant/anxiolytic drugs? Eur J Pharmacol 2007;573(1-3):139-47.

[8] Dhingra D, Sharma A. Antidepressant-like activity of $n$-hexane extract of nutmeg (Myristica fragrans) seeds in mice. J Med Food 2006;9(1):84-9.

[9] Dhir A, Kulkarni SK. Effect of addition of yohimbine (alpha-2-receptor antagonist) to the antidepressant activity of fluoxetine or venlafaxine in the mouse forced swim test. Pharmacology 2007;80(4):239-43.

[10] Dias Elpo Zomkowski A, Oscar Rosa A, Lin J, Santos AR, Calixto JB, Lúcia Severo Rodrigues A. Evidence for serotonin receptor subtypes involvement in agmatine antidepressant like-effect in the mouse forced swimming test. Brain Res 2004;1023(2):253-63.

[11] Evangelista S, Borsini F, Meli A. Evidence that muscimol acts in the forced swimming test by activating the rat dopaminergic system. Life Sci 1987;41(24):2679-84.

[12] Reny-Palasse V, Rips R. Potentiation by TRH of the effect of imipramine on the forced-swimming test. Br J Pharmacol 1985;85(2):463-70.

[13] Mikkelsen JD, Simonneaux V. The neuroanatomy of the kisspeptin system in the mammalian brain. Peptides 2009;30(1):26-33

[14] Roa J, Navarro VM, Tena-Sempere M. Kisspeptins in reproductive biology: consensus knowledge and recent developments. Biol Reprod 2011;85(4):650-60.

[15] Telegdy G, Tanaka M, Schally AV. Effects of the LHRH antagonist cetrorelix on the brain function in mice. Neuropeptides 2009;43(3):229-34.

[16] Telegdy G, Adamik A, Tanaka M, Schally AV. Effects of the LHRH antagonist cetrorelix on affective and cognitive functions in rats. Regul Pept 2010;159(1-3):142-7.

[17] Telegdy G, Tanaka M, Schally AV. Effects of the growth hormone-releasing hormone (GH-RH) antagonist on brain functions in mice. Behav Brain Res 2011;224(1):155-8.

[18] Tanaka M, Schally AV, Telegdy G. Neurotransmission of the antidepressant-like effects of the growth hormone-releasing hormone antagonist MZ-4-71. Behav Brain Res 2012;228(2):388-91.

[19] Telegdy G, Tiricz H, Adamik A. Involvement of neurotransmitters in urocortin-induced passive avoidance learning in mice. Brain Res Bull 2005;67(3):242-7. 